1 Loofah-based microalgae and cyanobacteria biocomposites for intensifying carbon

2

5

6

\title{
dioxide capture
}

Pichaya In-na ${ }^{1, \#}$, Abbas A. Umar ${ }^{1, \#}$, Adam D. Wallace² ${ }^{2}$ Michael C. Flickinger ${ }^{2}$, Gary S. Caldwell ${ }^{3}$ and Jonathan G.M. Lee ${ }^{1, *}$

1 - School of Engineering, Newcastle University

2 - Department of Chemical and Biomolecular Engineering, North Carolina State University

3 - School of Natural and Environmental Sciences, Newcastle University

\# - These authors contributed equally to the study

* - Corresponding author email: jonathan.lee@ncl.ac.uk

Address: Merz Court, Claremont Road, Newcastle upon Tyne, UK, Postcode: NE1 7RU Telephone: +44 (0) 191 208 5201; Fax: +44 (0) 1912085292

ORCID IDs where available:

Pichaya In-na: 0000-0001-8735-5821

Abbas A. Umar: 0000-0002-8073-1721

Michael Flickinger: 0000-0002-2192-2501

Gary Caldwell: 0000-0001-5687-6894

Jonathan Lee: 0000-0002-2539-5235

\section{Acknowledgements}

This work was supported by a Petroleum Technology Development Fund, Nigeria scholarship awarded to AU and a Newcastle University Doctoral scholarship awarded to PI. Additional support was provided by National Science Foundation CBET grant 1510072. We thank Juan Nogales, Spanish National Research Council (CSIC) in Madrid, Spain for the donation of S. elongatus PCC 7942, Peter McParlin for assistance with microalgae culturing, Michael Foster for assistance with SEM imaging, and Jack He, Rachel Hart and Matthew Walker for laboratory assistance. We are grateful to Justin Gladman of the Shared Material Instrument Facility, Duke University for access to CTscanning facilities. 
Microalgae and cyanobacteria have been evaluated for biological $\mathrm{CO}_{2}$ capture from flue gases for over 40 years; however, commercial open ponds and photobioreactors suffer many drawbacks including a slow rate of $\mathrm{CO}_{2}$ capture and high water usage. We evaluate an intensified 3D cell immobilisation approach with a small water demand, by coating latex binders onto defined surface area $\left(947 \mathrm{~m}^{2} \mathrm{~m}^{-3}\right)$ and void space $(81.78 \pm 4.41 \%)$ loofah sponge scaffolds, forming porous 3D biocomposites with three microalgae species; freshwater Chlorella vulgaris, marine Dunaliella salina and Nannochloropsis oculata, and two strains of freshwater Synechococcus elongatus cyanobacteria. Binder toxicity and adhesion screening protocols were established ahead of eight weeks semi-batch and six weeks continuous $\mathrm{CO}_{2}$ fixation trials. Acrylic and polyurethane binders were effective for microalgae, and bio-based (Replebin®) binders were suited for cyanobacteria. The highest average net $\mathrm{CO}_{2}$ fixation rates from each species were $0.17 \pm 0.01,0.25 \pm 0.01,0.12 \pm 0.01,0.68 \pm 0.18$ and $0.93 \pm 0.30 \mathrm{~g} \mathrm{CO}_{2} \mathrm{~g}^{-1}$ biomass $\mathrm{d}^{-1}$ for $C$. vulgaris, D. salina, N. oculata, S. elongatus PCC 7942 and S. elongatus CCAP 1479/1A respectively. This equates to predicted $\mathrm{CO}_{2}$ capture from scaled systems of up to $340.11 \pm 110 \mathrm{tCO}_{2} \mathrm{t}^{-1}$ biomass $\mathrm{yr}^{-1}$. Analysis of the kinetics of $\mathrm{CO}_{2}$ absorbtion and SEM imaging suggests that the cells were embedded within a polymer film that covered the scaffold. Biocomposites continuously fed with $5 \% \mathrm{CO}_{2}$ had high lipid contents approaching $70 \%$ dry weight. This biocomposite approach shows promise to intensify biological $\mathrm{CO}_{2}$ capture and possible application in bioenergy with carbon capture and storage (BECCS).

Keywords: algae oil; biocoating; bioenergy with carbon capture and storage (BECCS); carbon capture and storage; intensified carbon capture and utilisation; latex immobilisation

Carbon capture and storage (CCS) technologies are being developed as part of a suite of approaches to combat $\mathrm{CO}_{2}$-driven climate warming [1-6] by capturing $\mathrm{CO}_{2}$ from flue gas, particularly from major point source emitters. Post capture, the $\mathrm{CO}_{2}$ can be injected directly into geological reservoirs for long-term sequestration. However, these processes are expensive, require suitable geological features and, paradoxically, are energy intensive with a substantial carbon footprint [7].

CCS renders the $\mathrm{CO}_{2}$ permanently inaccessible. A parallel approach centred on carbon capture and utilisation (CCU—also known as carbon capture and conversion) aims to repurpose the captured $\mathrm{CO}_{2}$ for use in 
goods, e.g. plastics [8]. CCU approaches are advantageous insomuch as they produce marketable goods at the end of the $\mathrm{CO}_{2}$ value chain (potentially offsetting some of the associated $\mathrm{CO}_{2}$ capture costs) [9]; however, this is at the expense of the degree of permanency of $\mathrm{CO}_{2}$ sequestration [1].

It is possible to mimic nature and capture $\mathrm{CO}_{2}$ using biological approaches by harnessing and engineering the innate $\mathrm{CO}_{2}$-fixing capabilities of photoautotrophic organisms (plants, algae, phototrophic bacteria) $[10,11]$. Phototrophs fix $\mathrm{CO}_{2}$ into sugars using the bidirectional enzyme ribulose-1,5-bisphosphate carboxylase/oxygenase (RuBisCo), with algae and cyanobacteria further benefiting from carbonic anhydrase as a carbon concentrating mechanism [12]. $\mathrm{CO}_{2}$ captured through biological pathways is particularly amenable for $\mathrm{CCU}$ exploitation, potentially yielding additional benefits over and above the final carbon product, such as remediating wastewaters [13]. However, to support their carbon fixing pathways, phototrophs require exposure to light (natural or artificial) in addition to water and nutrients; thus adding significant costs to the process [10].

Numerous studies have shown that microalgae and cyanobacteria absorb $\mathrm{CO}_{2}$ from industrial flue gas (up to $20 \% \mathrm{v} / \mathrm{v}$ ) [14], with evidence that some species may even prefer flue gas over pure $\mathrm{CO}_{2}$ streams [15]. These organisms (depending on species) can readily convert $\mathrm{CO}_{2}$ into valuable metabolites e.g. lipids for biodiesel conversion or synthesis of bioplastics, with some species (especially those belonging to the Synechococcus and Synechocystis genera) capable of storing $\mathrm{CO}_{2}$ as calcium carbonate $\left(\mathrm{CaCO}_{3}\right)$; potentially consolidating both $\mathrm{CCU}$ and CCS in one organism [16]. Furthermore, many microalgae and cyanobacteria can tolerate reasonably high temperatures [17], thus reducing the need for flue gas cooling prior to contact.

Approximately $70 \%$ of microalgae and cyanobacteria carbon capture trials have used open pond growth systems, which require substantial land and water, are vulnerable to biological contamination [18], and are exposed to variable weather and climate conditions, which compromise performance. Closed culture systems (photobioreactors, PBR) can overcome many of these drawbacks [19-21]; however, PBRs are not without their operational, performance, and sustainability challenges [22, 23].

If microalgae and cyanobacteria are to make meaningful contributions to CCS and CCU, new approaches that significantly intensify the rate of $\mathrm{CO}_{2}$ absorption are needed. One such approach - the concentration, encapsulation and immobilisation of photosynthetic organisms within a thin matrix coating — draws inspiration from plant leaves and natural biofilms. These matrix-entrapped live organisms, also known as biocomposites, are being evaluated for applications such as intensifying wastewater treatment, microbial air purification, and carbon capture [13]. The increased cell loading facilitated by immobilisation can significantly enhance volumetric absorption productivity, biosorption capacity and microalgae specific activity [24]. In addition, biocomposites 
require less space and are easy to handle $[25,26]$. However, the mechanical limitations of the predominant immobilisation technology (hydrogels) fails to support cells for long-term storage under dry or frozen conditions, resulting in cell damage and leaching [27]. Alternative adhesive coating techniques that are robust, inexpensive and easy to implement at scale using industrial coating technology may overcome these problems. For example, Bernal [28] immobilised cyanobacteria within a latex binder wet coating on hydrated paper, yielding a 10-fold greater specific photosynthetic rate relative to suspension cultures, with $\mathrm{CO}_{2}$ fixation sustained for up to 500 hours. Additionally, Flickinger [29] argued that latex coatings can be manipulated using bimodal blends with non-toxic nanoparticles to create sufficient porosity while still protect the immobilised cells from bacterial contamination. In addition to paper scaffold systems, numerous synthetic scaffolds have been tested with varying degrees of success, including textiles, polyurethane foam, porous glass and ceramics [13,30]; however, fixation rate and performance suffered from poor cell retention and/or toxicity. Natural scaffold materials may present more options. Loofah sponge (the dried fruit of the edible Luffa plant) offers a natural high surface area scaffold with threedimensional (3D) geometry. Commercially, the xylem-rich fibrous structure is used as a bathing and exfoliating aide, has been studied for blending with plastics to create bioplastics packaging [31], and has been tested for numerous biotechnology applications [8, 32-35]. Microalgae and fungi have successfully been immobilised onto loofah for metal recovery from wastewater, producing enhanced biosorption capacities relative to suspension culture controls [36-39]. The highly porous structure should support excellent gas exchange and facilitate effective light transmission to a reasonable depth for immobilised phototrophs. Additionally, the moderately hydrophilic fibres [40] are effective at retaining moisture within the structure. To our knowledge, loofah-based biocomposites have yet to be assessed for gaseous carbon capture applications. Using an iterative screening process, the current work has evaluated the toxicity and effectiveness of latex binder coatings to immobilise industrially relevant live microalgae and cyanobacteria onto loofah to develop stable and inexpensive 3D biocomposites (see Fig. S1) for carbon capture applications, with an initial target operational longevity exceeding 1000 hours under both semibatch and continuous $\mathrm{CO}_{2}$ absorption tests.

\section{Material and methods}

\subsection{Organisms, media and growth conditions}

Three microalgae species (Chlorella vulgaris (CCAP 211/63) - freshwater, Nannochloropsis oculata (CCAP 849/1) and Dunaliella salina (CCAP 19/30) — marine) and two freshwater cyanobacteria strains (Synechococcus elongatus CCAP 1479/1A and PCC 7942) were used to produce biocomposites with petroleum (synthetic) or bio- 
119 based binders. C. vulgaris and S. elongatus PCC 7942 were cultivated in BG11 medium, S. elongatus CCAP 120 1479/1 A in JM medium, and D. salina and N. oculata in F/2 medium. All cultures were grown in $10 \mathrm{~L}$ 121 polycarbonate carboys (Nalgene), with constant HEPA filtered aeration using an aquarium pump (KOI AIR 50 Blagdon), and maintained at the default conditions of our microalgae growth suite i.e. $18 \pm 2{ }^{\circ} \mathrm{C}$ with a $16: 8 \mathrm{~h}$ light:dark cycle with 2,500 lux $\left(\approx 30.5 \mu \mathrm{mol} \mathrm{m} \mathrm{m}^{-2} \mathrm{~s}^{-1}\right.$; [41] $)$ of illumination provided by $30 \mathrm{~W}$ daylight-type fluorescent tubes (Sylvania Luxline Plus, $n=6$ ).

\subsection{Latex binders}

Thirteen synthetic acrylic, styrene and polyurethane latex binder emulsions from a library of proprietary and commercial sources at North Carolina State University were tested (Table S1). Most of the binders have been tested in previous studies for cell immobilisations [28]. Six bio-based (plant based; Replebin®) emulsions were purchased from the AURO Paint Company, UK (Table S2) based on their distinct applications and because they are commercially available and environmentally friendly. Synthetic binders were tested with microalgae and biobased binders were tested with cyanobacteria because some studies suggest that cyanobacteria tend to be more sensitive than microalgae to biocides present in synthetic binders $[42,43]$. The $\mathrm{pH}$ of all binders was adjusted to within 7.5-6.5 using 0.1 and $0.5 \mathrm{M}$ acetic acid. Solids content was determined using dry weight by drying at $100{ }^{\circ} \mathrm{C}$ overnight. The synthetic binders were numbered from S1 to S13 (S stands for synthetic), while the biobased binders were numbered from B1 to B6 (B stands for bio-based). Methods for biocoatings formulation (cells plus binder), together with the approached used to assess toxicity and adhesion performance are described in supplementary material and methods.

Loofah sponges were purchased from retail outlets. The surface area was determined as follows: a representative sample (approximately $5 \times 1 \times 1 \mathrm{~cm}$ ) was embedded in an epoxy resin within a silicon mold and cured for $48 \mathrm{~h}$ at $20{ }^{\circ} \mathrm{C}$ (100 parts EpoxiCure 2 to 23 parts hardener by weight, containing five drops of black acrylic liquid pigment to enhance contrast). Sections (1 mm thick) were cut using a Buehler IsoMet Low Speed Saw at 100 rpm. Sections were imaged using a digital HD camera (Canon EOS M10 fitted with an EF-M 15-45 mm 1:3.5-6.3 IS STM Canon zoom lens) and the loofah strand perimeter per area $\left(\mathrm{mm} \mathrm{mm}^{-2}\right)$ was determined using ImageJ software. Light penetration (transmitted photosynthetic active radiation, PAR) through different loofah sections (whole loofah in the vertical orientation, $100.8 \pm 0.27 \mathrm{~mm}$ height; whole loofah horizontal orientation, $54.63 \pm$ $0.72 \mathrm{~mm}$ diameter; half loofah horizontal orientation, $13.01 \pm 0.43 \mathrm{~mm}$ ) was measured using a Skye PAR Quantum Sensor under natural sunlight (1500 hrs BST, July $3^{\text {rd }}$, 2019, full sunlight; Fig. S2), and calculated using equation 
1. The sensor was held within a lightproof tube to prevent peripheral light from distorting the readings. Ambient sunlight PAR (mean \pm StDev $=1902 \pm 39 \mu \mathrm{mol} \mathrm{m}^{-2} \mathrm{~s}^{-1}$ ) was recorded before and after each loofah sample. All measurements were in triplicate.

$$
\% \text { PAR loss with depth }\left(\mathrm{mm}^{-1}\right)=\frac{\text { [transmitted PAR/ambient PAR] }}{\text { distance }}
$$

\subsection{Semi-batch $\mathrm{CO}_{2}$ fixation tests}

To evaluate the ability of the biocomposites to absorb $\mathrm{CO}_{2}$, semi-batch tests were carried out using samples prepared in the following way. For the microalgae species, $70 \mu \mathrm{l}$ of biocoating formulation of known cell density (5.0\% w/v cell content and 5.0\% solids binder) was immobilised onto the loofah surface, whereas $600 \mu \mathrm{l}$ of biocoating formulation $(2.5 \% \mathrm{w} / \mathrm{v}$ cell content and $2.5 \%$ solids binder) was used for the cyanobacteria. To limit any self-shading effects, a conservative cell loading strategy was adopted relative to a comparative biocomposite study [28]. Each formulation was carefully pipetted onto one end of dried, autoclaved, pre-weighed loofah strips (dimension $1 \times 5 \mathrm{~cm} \mathrm{w} \times \mathrm{h}$ ) and dried overnight at $20^{\circ} \mathrm{C}$. It was assumed that all cells added to the biocoating were successfully immobilised within the adhesive binder; however, the macroporous structure of the loofah (Fig. S2) caused some of the formulation to flow to waste, therefore a 100\% cell loading efficiency was not achieved. To account for this, the mass of formulation dried onto the loofah was determined and normalised to a reference dried formulation. Abiotic controls comprising loofah, binder and sterile growth medium were similarly established.

For semi-batch $\mathrm{CO}_{2}$ fixation tests (eight weeks running time), the biocomposites were placed in triplicate into $50 \mathrm{ml}$ glass bottles containing $5 \mathrm{ml}$ of growth medium (Fig. S3). The bottles were sealed with $20 \mathrm{~mm}$ butyl rubber stoppers and crimped using silver aluminium caps. Once sealed, $45 \mathrm{ml}$ of $5 \% \mathrm{CO}_{2} /$ air gas mixture was injected with a syringe. Triplicate suspension controls using appropriate growth media were established with a cell density equivalent to the cell loading within the biocomposite. The samples were maintained at $18 \pm 2{ }^{\circ} \mathrm{C}$ with a 16:8 light:dark photoperiod at 2500 lux. The percentage of $\mathrm{CO}_{2}$ fixed was determined every two days by extracting the headspace with an airtight syringe and injecting into a GEOTech G100 infrared absorption $\mathrm{CO}_{2}$ meter. The equivalent volume of $\mathrm{CO}_{2}$ gas mixture was refreshed.

Due to cell outgrowth from the cyanobacteria in the semi-batch tests, only C. vulgaris, D. salina and $N$. oculata were evaluated for the continuous $\mathrm{CO}_{2}$ tests (six weeks running time). Unfortunately, there were insufficient quantities of some binders following the semi-batch tests, therefore only binders S1 and S3 were tested with $C$. vulgaris, $\mathrm{S} 1$ and $\mathrm{S} 11$ with D. salina, and S4 and S5 with $N$. oculata. 


\subsection{Biocomposite microstructure analysis}

Raw loofah was imaged in 3D using a Nikon XTH 225 ST high resolution x-ray computed tomography scanner with a $225 \mathrm{kV}$ UltraFocus Reflection Based Signal and Tungsten Target with a Perkin Elmer 1620 AN3 CS CT detector. The biocomposites were analysed using scanning electron microscopy (SEM) before and after adhesion testing and after the eight weeks semi-batch net $\mathrm{CO}_{2}$ fixation test. Samples were dried at $105{ }^{\circ} \mathrm{C}$ for $3 \mathrm{~h}$ and stored in a desiccator before being attached to $12 \mathrm{~mm}$ diameter pin stubs using carbon tape. The instrument was a Hitachi TM 3000 SEM equipped with a backscattered electrons system for digital image acquisition. All biocomposites were observed in two or more randomised locations using a 5 or $15 \mathrm{kV}$ accelerating voltage. Each location was imaged multiple times using sequential magnifications ranging from $15 \times$ to $30,000 \times$ to characterise surface topography, cell distribution and available pore space.

\subsection{Analysis of $\mathrm{CO}_{2}$ transfer kinetics}

The kinetics of $\mathrm{CO}_{2}$ transport from the gas phase to the cells immobilised with coatings on loofah scaffolds were analysed using the $\mathrm{CO}_{2}$ absorption rate data from the semi-batch tests and by solving the unsteady state diffusion equation. The rate of $\mathrm{CO}_{2}\left(\mathrm{R}_{\mathrm{CO} 2}\right)$ is given by equation 2 , where $\mathrm{Ka}_{\mathrm{C}}$ is the volumetric transfer coefficient $\left(\mathrm{s}^{-1}\right)$ and $\mathrm{c}$ is the concentration in the gas or liquid phase $\left(\mathrm{mols} \mathrm{m}^{-3}\right)$.

$$
R_{\mathrm{CO}_{2}}\left(\operatorname{mols~} \mathrm{m}^{3} \mathrm{~s}^{-1}\right)=K a_{C} c
$$

Equation 2 is written for $\mathrm{CO}_{2}$ transport from the bulk liquid or gas phase to inside the cell assuming that the $\mathrm{CO}_{2}$ concentration in the cell is zero due to photosynthesis. For the suspension controls, the cells were surrounded by liquid and the volumetric transfer coefficient was calculated by solving equation 3 , where $c^{\mathrm{L}}$ is the $\mathrm{CO}_{2}$ concentration in the liquid (mols m $\left.{ }^{-3}\right), D_{\mathrm{CO}_{2}}^{L}$ is the diffusivity of $\mathrm{CO}_{2}$ in the culture medium $\left(1.92 \times 10^{-9} \mathrm{~m}^{2} \mathrm{~s}^{-1}\right), \mathrm{t}$ is the time (s) and $\mathrm{z}$ is the vertical distance in the vial measured from the gas-liquid interface $(\mathrm{m})$.

$$
\frac{\partial c^{L}}{\partial t}=D_{C O_{2}}^{L} \frac{\partial^{2} c^{L}}{\partial z^{2}}-K a_{C} c^{L}
$$

Equilibrium was assumed to exist at the interface between the gas and the culture medium. The equilibrium was modelled using Henry's Law. For the biocomposite samples the cells are surrounded by gas and the volumetric transfer coefficient was calculated by solving equation 4 , where $\mathrm{c}^{\mathrm{G}}$ is the $\mathrm{CO}_{2}$ concentration in the gas (mols $\mathrm{m}^{-}$ $\left.{ }^{3}\right), D_{\mathrm{CO}_{2}}^{G}$ is the diffusivity of $\mathrm{CO}_{2}$ in the gas phase $\left(1.6 \times 10^{-5} \mathrm{~m}^{2} \mathrm{~s}^{-1}\right)$ and $\mathrm{x}$ and $\mathrm{y}$ are horizontal distances perpendicular to the vertical axis of the sample vial (m). 


$$
\frac{\partial c^{G}}{\partial t}=D_{C O_{2}}^{G}\left(\frac{\partial_{2} c^{G}}{\partial x^{2}}+\frac{\partial_{2} c^{G}}{\partial y^{2}}\right)-K a_{C} c^{G}
$$

Equations 3 and 4 were solved over the 48 hour period between fresh gas injections $\left(c_{0}^{G}=2.04 \mathrm{mols} \mathrm{m}^{-3}\right)$. The value of the transfer coefficient was adjusted until the concentrations predicted by equations 3 and 4 matched the values measured in the gas at the end of the 48 hours period. Data from day 14 of the semi-batch test onwards were used. Full details about the solution of equations 3 and 4 are given in the supplementary materials (Figs S4S7, Table S3).

\subsection{Continuous $\mathrm{CO}_{2}$ fixation tests}

After completing and analysing the data from the semi-batch tests, an experiment was set up to demonstrate that biocomposites can be used to continuously capture $\mathrm{CO}_{2}$ and convert it into a useable product. The lipid producing species $C$. vulgaris, D. salina and $N$. oculata were chosen for these tests since we sought to demonstrate that the biocomposites could produce a commercially viable product. Approximately $1 \mathrm{~g}$ of wet cell paste (see supplementary material and methods) of known cell density $\left(1.13 \times 10^{9}\right.$ cells $\left./ \mathrm{ml}\right)$ was mixed by vortex with $1 \mathrm{ml}$ of $\mathrm{pH}$ adjusted synthetic latex binder and $50 \mathrm{ml}$ of growth medium. Each formulation was poured into individual $100 \mathrm{ml}$ beakers containing loofah $(50 \times 55 \mathrm{~mm}, \mathrm{~h} \times \mathrm{d})$ and dried at $30^{\circ} \mathrm{C}$ in a shaking incubator $(250 \mathrm{rpm}$ for 48 to $60 \mathrm{~h}$ ) (Fig. S8). After drying, the biocomposites were placed into duplicate $100 \mathrm{ml}$ Duran glass bottles connected to a continuous $\mathrm{CO}_{2}$ flow rig (Fig. S9) constructed from a polypropylene tube (length $=91.5 \mathrm{~cm}$, diameter $=63.0$ $\mathrm{mm}$, wall thickness $=5.0 \mathrm{~mm}$, internal diameter $=53.0 \mathrm{~mm})$. Each bottle was connected via $6.35 \mathrm{~mm}(1 / 4 \mathrm{inch})$ PTFE tubes to a continuous flow of $5 \% \mathrm{CO}_{2} /$ air mixture at $40 \mathrm{~cm}^{3} \mathrm{~min}^{-1}$. Gas flow was regulated using a ColeParmer MC-series gas mass flow controller and distributed equally to each bottle using needle valves. The gas outlet was collected using a $1 \mathrm{~L}$ airtight sampling gas bag and analysed every $24 \mathrm{~h}$ using a G100 GeoTech $\mathrm{CO}_{2}$ meter. Approximately $5 \mathrm{ml}$ of growth medium were refreshed every $72 \mathrm{~h}$. Growth conditions matched the semibatch $\mathrm{CO}_{2}$ fixation test. Abiotic controls were prepared and tested in the same manner.

The opacity of the binders, coupled with the structural complexity of the loofah, made direct cell counts impractical, therefore growth was estimated based on mass changes. The net quantity of $\mathrm{CO}_{2}$ fixed by the immobilised cells (dry biomass basis) was calculated based on the total immobilised biomass (after normalising to the abiotic and growth medium controls). Biomass was determined based on the difference in weight of the loofah before and after immobilisation after binder density was taken into account. $\mathrm{As}^{\mathrm{CO}_{2}}$ readings were taken every two days, the net $\mathrm{CO}_{2}$ fixation rate was calculated using equation 5 , where $P$ is gas pressure $(\mathrm{kPa}), V$ is gas volume (1), $R$ is the ideal gas constant $\left(\mathrm{J} \mathrm{K} \mathrm{mol}^{-1}\right)$ and $T$ is temperature (K). 
net $\mathrm{CO}_{2}$ fixation rate $\left(\mathrm{mol} \mathrm{CO}_{2} \mathrm{~g}_{\text {biomass }}^{-1}\right.$ day $\left.^{-1}\right)=\frac{\% \mathrm{CO}_{2} \text { fixed } \times \frac{P V}{R T}}{\text { Immobilised dried biomass }(\mathrm{g}) \times 2 \text { days }}$

To calculate the $\mathrm{CO}_{2}$ fixation rate per unit surface area, the following assumptions were made: the percentage of void area was the same throughout the structure, i.e. the perimeter to area ratio is equivalent to surface area per volume $\left(\mathrm{mm}^{-2} \mathrm{~mm}^{-3}\right)$; loofah does not consume $\mathrm{CO}_{2}$; the biocoating formulation was uniformly distributed across the loofah surface; and there was no outgrowth of cells beyond the estimated surface area.

\subsection{Lipid extraction}

At the end of the continuous $\mathrm{CO}_{2}$ test the total lipid content of the C. vulgaris and D. salina biocomposites were analysed using a modified Bligh and Dyer (1959) gravimetric method [44] (N. oculata was not included due to a substantial loss of cells during the experiment). Before lipid extraction, the biocomposites were dried at $105{ }^{\circ} \mathrm{C}$ for $24 \mathrm{~h}$ to remove any absorbed growth medium, then freeze dried using liquid nitrogen and ground by pestle and mortar. For the first extraction, approximately 40 ml methanol: chloroform: $\mathrm{dH}_{2} \mathrm{O}(2: 1: 0.8 \mathrm{v} / \mathrm{v} / \mathrm{v})$ was added to 50 $\mathrm{ml}$ polypropylene centrifuge tubes with the samples and left to react for $48 \mathrm{~h}$. The samples were filtered to separate solid residue and supernatant and transferred into a new $50 \mathrm{ml}$ tube. For the second extraction, $30 \mathrm{ml}$ of the solvent mix was added and left to react for $24 \mathrm{~h}$. The topmost liquid layer (methanol and water) in each extraction was carefully removed and the chloroform/lipid layer was transferred to a pre-weighed vial. Once completely dried, the vial was weighed to calculate the percentage lipid per biomass dry weight. Total lipids were also extracted from the abiotic and loofah-only controls and subtracted from the measured lipid content of biocomposites.

\subsection{Statistics}

Data were statistically analysed using Minitab 17 and all methods were chosen based on Smith [45]. Toxicity and adhesion data were not normally distributed and were analysed using Kruskal-Wallis tests with Mann-Whitney U-tests. Cumulative net $\mathrm{CO}_{2}$ fixation data from the semi-batch test were analysed by one-way analysis of variance (ANOVA) with Tukey's Honest Significant Difference post-hoc test at 34 and 46 days for microalgae and cyanobacteria respectively (corresponding to the final data obtained from the suspension controls) and at the termination of the experiment (56 days). Cumulative net $\mathrm{CO}_{2}$ fixation data from the continuous test were analysed by ANOVA with Tukey's post-hoc test for all the biocomposites at the final time period of the suspension controls (34 days) and at the termination of the experiment (42 days). The percentage lipid content data were also analysed using ANOVA. 


\subsection{Loofah characterisation}

The loofah had a surface area available for coating equivalent to $947 \mathrm{~m}^{2} \mathrm{~m}^{-3}$ with a void space (for gas exchange and light penetration) of $81.78 \pm 4.41 \%$. The loss in absolute transmitted PAR was greatest in the whole loofah in the horizontal orientation (from $1927 \pm 20$ to $71 \pm 22 \mu \mathrm{mol} \mathrm{m}^{-2} \mathrm{~s}^{-1}$ ), followed by the whole loofah in the vertical orientation (from $1851 \pm 11$ to $98 \pm 2 \mu \mathrm{mol} \mathrm{m}^{-2} \mathrm{~s}^{-1}$ ), and the half loofah (from $1930 \pm 2$ to $146 \pm 3 \mu \mathrm{mol} \mathrm{m}^{-2} \mathrm{~s}^{-1}$ ); however, when converted to the percentage loss in PAR per unit distance the half loofah was the worst performer followed by the horizontal whole loofah then the vertical whole loofah (Table S4).

\subsection{Latex binder toxicity and adhesion screening}

A decision matrix based on toxicity and adhesion performance was applied to select the most suitable binders for subsequent net $\mathrm{CO}_{2}$ fixation tests (Fig. 1) [46]. Most of the synthetic binders clustered at the extremes of the matrix, whereas the bio-based binders were more evenly distributed. This was due to the majority of synthetic latexes significantly inhibiting microalgae growth relative to the suspension control (Fig. S10a-c) while bio-based binders B5 and B6 significantly enhanced the growth of S. elongatus CCAP 1479/1A and PCC 7942 by roughly 1.5- and 3-fold respectively (Fig. S10d-e). During the seven day toxicity test, toxic binders showed photobleaching unlike non-toxic binders (as an example, see Fig. S11). Without complete knowledge of proprietary commercial binder surface chemistry and formulations it is not possible to determine the relative contribution of each component to the observed toxicity.

For adhesion tests, thirteen acrylic and polyurethane latex binders were tested with $C$. vulgaris, however a limited supply of the synthetic binders necessitated that only the five least toxic binders were tested with $N$. oculata and D. salina. The binders retaining most cells were $\mathrm{S} 9, \mathrm{~S} 1$ and $\mathrm{S} 11$ for $C$. vulgaris, $N$. oculata and D. salina respectively, with each releasing less than 1\% of cells (Fig. S12). Binders B1 and B5 were the leading bio-based binders with $0.61 \%$ of S. elongatus PCC 7942 and 3.49\% of CCAP 1479/1A released (Fig. S12).

SEM analysis of the biocomposite structure was conducted before and after cell immobilisation. In addition to covering the loofah strands, the binders tended to form between the pore spaces potentially reducing the overall porosity of the structure with possible implications for gas exchange and light penetration. Fig. 2 shows contrasting examples of effective (displaying a smooth surface; Fig. 2b) and poorly performing synthetic binders (cracked during drying; Fig. 2c). Cracked binders could not adequately retain the cells within the structure as indicated by poor adhesion data. The equivalent S. elongatus biocomposites are presented in Fig. 3 and Fig. S13. The least effective binders (B4 for CCAP 1479/1A; Fig. 3a-d and B3 for PCC 7942; Fig. S13a-d) deteriorated 
rapidly, whereas binders B5 (CCAP 1479/1 A) (Fig. 3e-h) and B1 (PCC 7942) (Fig. S13e-h) retained the cells on the loofah surface in the same form as prior to the adhesion test.

As a result from the screening, three synthetic binders were selected per microalga; binder S1 was selected for all three species, S8 for D. salina and N. oculata, $\mathrm{S} 3$ and $\mathrm{S} 10$ for $C$. vulgaris, $\mathrm{S} 11$ for $D$. salina and $\mathrm{S} 4$ for $N$. oculata. Binder B6 was selected for S. elongatus PCC 7942 and binder B5 for CCAP 1479/1A.

\section{3. $\mathrm{CO}_{2}$ fixation rates in the semi-batch tests}

With excellent $\mathrm{pH}$ and temperature tolerances [47] loofah may be a useful candidate scaffold for capture from gases containing $\mathrm{CO}_{2}$, for example the flue gas from combustion processes. A liquid absorption capacity of up to $18.4 \mathrm{~g} \mathrm{~g}^{-1}$ of fibers [36] should deliver sufficient hydration and sustenance to bound cells via capillary action over extended periods, in a mechanism similar to the cellulosic sheet biofilm-based photobioreactor described by Hamano and co-workers [48]. To test this, we utilised semi-batch and continuous $\mathrm{CO}_{2}$ fixation tests over extended time periods (eight and six weeks respectively). Fig. 4 shows the cumulative net $\mathrm{CO}_{2}$ fixation of the biocomposites over the 8-week semi-batch testing period. The microalgae and cyanobacteria suspension controls were terminated after 34 and 46 days respectively due to culture failure - likely due to a combination of nutrient exhaustion and self-shading, due in part to the initial high inoculum density required to match the biocomposite cell loading. In contrast, only a very limited number of loofah treatments failed to establish, specifically one $C$. vulgaris replicate with both binders $\mathrm{S} 3$ and $\mathrm{S} 10$. In all cases, net $\mathrm{CO}_{2}$ fixation rates from the biocomposites substantially exceeded the suspension controls (Fig. 4, Table 1). For C. vulgaris (Fig. 4a), binder S1 had the highest net fixation rate (2.52 $\pm 0.10 \mathrm{mmol} \mathrm{g}^{-1} \mathrm{~d}^{-1}$ - where $\mathrm{g}$ refers to $\mathrm{g}$ of phototroph biomass not total biocomposite) followed by $\mathrm{S} 3$ $\left(1.73 \pm 1.50 \mathrm{mmol} \mathrm{g}^{-1} \mathrm{~d}^{-1}\right)$ and $\mathrm{S} 10\left(1.16 \pm 1.05 \mathrm{mmol} \mathrm{g}^{-1} \mathrm{~d}^{-1}\right)$. A reduction in net fixation rate was noted after approximately 33 days, however each biocomposite remained functional up to the termination of the test. There were no significant differences between binders at 34 days or at the termination of the experiment - likely an artefact of reduced statistical power following the loss of one replicate for two of the binders. For D. salina (Fig. 4b, Table 1), binder S1 $\left(1.96 \pm 0.48 \mathrm{mmol} \mathrm{g}^{-1} \mathrm{~d}^{-1}\right)$ was significantly outperformed by both binders $\mathrm{S} 11(2.99 \pm$ $\left.0.41 \mathrm{mmol} \mathrm{g}^{-1} \mathrm{~d}^{-1}\right)$ and $\mathrm{S} 8\left(2.95 \pm 0.25 \mathrm{mmol} \mathrm{g}^{-1} \mathrm{~d}^{-1}\right)$ at both time points. There was no evidence of a reduction in performance by the end of the trial. There were no statistical differences between the performances of the $N$. oculata biocomposites at either time point (Fig. 4c, Table 1) with the highest rate $\left(2.71 \pm 0.24 \mathrm{mmol} \mathrm{g}^{-1} \mathrm{~d}^{-1}\right)$ achieved with binder $\mathrm{S} 4$. As with the $D$. salina trials, there was no evidence of any reduction in performance over the eight weeks. S. elongatus CCAP 1479/1A yielded the highest net fixation rate of all the biocomposites (21.18 $\left.\pm 6.87 \mathrm{mmol} \mathrm{g}^{-1} \mathrm{~d}^{-1}\right)$, over ten times higher than its suspension control $\left(2.08 \pm 0.13 \mathrm{mmol} \mathrm{g}^{-1} \mathrm{~d}^{-1}\right)$. The S. elongatus 
PCC 7942 biocomposite was $15.38 \pm 4.06 \mathrm{mmol} \mathrm{g}^{-1} \mathrm{~d}^{-1}$, almost 9-fold higher than its suspension control $(1.77 \pm$ $\left.0.12 \mathrm{mmol} \mathrm{g}^{-1} \mathrm{~d}^{-1}\right)$. There were no significant differences between the biocomposite performances at either time point (Fig. 4d, Table 1).

\section{4 $\mathrm{CO}_{2}$ transfer kinetics}

Using the experimental data from the semi-batch tests, the volumetric $\mathrm{CO}_{2}$ transfer coefficients for the suspended culture controls and the biocomposites were calculated. These data are presented in Table 2 and Figure 5 and show that the $\mathrm{CO}_{2}$ transfer coefficient is lower for the biocomposites compared to the suspended cultures. This was expected as by incorporating the cells into the binder an additional transfer resistance has been added. The transfer coefficients are higher for biocomposites incorporating the cyanobacteria compared to microalgae because the cells are smaller and a greater number were included per unit volume of coating, leading to a higher cell surface area for $\mathrm{CO}_{2}$ transfer.

In an attempt to determine the nature of the mass transfer resistance in the biocoatings, the data in Table 2 were analysed in more depth. First, using cell surface areas for the suspended cultures, values of the coefficient for transfer through the cell walls and cell internals were calculated, $\mathrm{k}_{\mathrm{cell}}\left(\mathrm{mols} \mathrm{m}^{-2} \mathrm{~s}^{-1} \cdot\left(\mathrm{mols} \mathrm{m}^{-3}\right)^{-1}\right)$. Next, using cell surface areas for the biocomposites, values of the coefficient for transfer through the binder layer, cell walls and cell internals were calculated, $\mathrm{k}_{\mathrm{BC}}$. It was assumed that the resitances due to the cell and the binder were additive as shown in equation 6.

$$
\frac{1}{k_{B C}}=\frac{1}{k_{\text {binder }}}+\frac{1}{k_{\text {cell }}}
$$

Equation 6 was used to calculate values of the transfer coefficient for the binder, $\mathrm{k}_{\mathrm{binder}}$. The thickness of the binder layer applied to the loofah was calculated based on the assumption that the volume of the biocoating formulation in the semi-batch tests $(600 \mu \mathrm{l})$ was uniformly distributed over the surface of the binder. This gave an average thickness for the binder layer of $26 \mu \mathrm{m}$. Being a solid, the resistance of the binder layer is given by equation 7. In this equation, $\delta_{\mathrm{B}}$, is the thickness of the binder layer and $\mathrm{D}_{\mathrm{B}}$ is the $\mathrm{CO}_{2}$ diffusivity in the binder layer $\left(\mathrm{m}^{2} \mathrm{~s}^{-1}\right)$.

$$
k_{\text {binder }}=\frac{D_{B}}{\delta_{B}}
$$

Equations 6 and 7 were used to calculate values for the diffusivity in the binder. The results of these calculations (Table 3) show that the $\mathrm{CO}_{2}$ diffusivities in the binder are of the order of $10^{-15}-10^{-13} \mathrm{~m}^{2} \mathrm{~s}^{-1}$. By comparing these values with the diffusivity of gases in microporous solids $\left(\sim 10^{-8} \mathrm{~m}^{2} \mathrm{~s}^{-1}\right)$ [49], diffusivities of gases in liquids $\left(\sim 10^{-}\right.$ $\left.{ }^{9} \mathrm{~m}^{2} \mathrm{~s}^{-1}\right)$ and the diffuvity of $\mathrm{CO}_{2}$ in polymer films $\left(\sim 10^{-13} \mathrm{~m}^{2} \mathrm{~s}^{-1}\right)$ [50], they imply that the cells are covered by a solid layer of polymer, a conclusion which is supported by the SEM images in Figure 3. 


\subsection{Continuous $\mathrm{CO}_{2}$ fixation tests and lipid content}

In the continuous $\mathrm{CO}_{2}$ exposure tests, as with the semi-batch test, each biocomposite substantially outperformed its respective suspension control (C. vulgaris: $\mathrm{ANOVA}, \mathrm{F}=25.47, \mathrm{DF}=2, \mathrm{P}=0.013 ;$ D. salina: $\mathrm{ANOVA}, \mathrm{F}=41.39$, $\mathrm{DF}=2, \mathrm{P}=0.007 ; N$. oculata: ANOVA, $\mathrm{F}=9.60, \mathrm{DF}=2, \mathrm{P}=0.05)$ when analysed at the final time period of the suspension controls (34 days). However, there were no significant differences between biocomposites of the same species at the termination of the experiment (42 days). The highest cumulative $\mathrm{CO}_{2}$ fixation was from $D$. salina with binder S11 (239.15 $\left.\pm 11.29 \mathrm{mmol} \mathrm{g}^{-1}\right)$ (Fig. 6b), corresponding to a daily cumulative $\mathrm{CO}_{2}$ fixation at six weeks of $5.69 \pm 0.24 \mathrm{mmol} \mathrm{g}^{-1} \mathrm{~d}^{-1}$ (Table 4), which was approaching 18 times higher than the suspension culture $\left(0.32 \pm 0.05 \mathrm{mmol} \mathrm{g}^{-1} \mathrm{~d}^{-1}\right)$. The highest $\mathrm{CO}_{2}$ fixation from $C$. vulgaris was in combination with binder $\mathrm{S} 3(165.25$ $\pm 6.53 \mathrm{mmol} \mathrm{g}^{-1}$ or $\left.3.93 \pm 0.16 \mathrm{mmol} \mathrm{g}^{-1} \mathrm{~d}^{-1}\right)$ followed by $\mathrm{S} 1\left(150.37 \pm 29.76 \mathrm{mmol} \mathrm{g}^{-1}\right)$ (Fig. 6a, Table 4). $N$. oculata fixed $162.43 \pm 54.80 \mathrm{mmol} \mathrm{g}^{-1}$ with binder S4 (Fig. 6c). However, there was a poor adhesive relationship between $N$. oculata and the binders that allowed cells to escape the structure and grow in the pool of liquid growth medium; therefore, the $N$. oculata $\mathrm{CO}_{2}$ fixation data should be interpreted cautiously. Comparing between the semi-batch and continuous tests (discounting $N$. oculata), the continuous approach yielded consistently greater $\mathrm{CO}_{2}$ fixation rates, equating to relative performance improvements of $42 \%$ for C. vulgaris with binder $\mathrm{S} 1,90 \%$ for D. salina with binder S11, 117\% for C. vulgaris with binder S1 and 127\% for C. vulgaris with binder S3.

Immobilisation significantly increased the lipid content of both $C$. vulgaris (ANOVA, F=33.28, DF=2, $\mathrm{P}=0.009$ ) and $D$. salina (ANOVA, $\mathrm{F}=68.14, \mathrm{DF}=2, \mathrm{P}=0.003$ ) compared to their suspension controls. The $C$. vulgaris biocomposites had dry weight lipid contents of $69.38 \pm 1.27 \%$ and $51.96 \pm 11.84 \%$ for binders $\mathrm{S} 1$ and S3 respectively, compared with $14.53 \pm 0.47 \%$ for the suspension control (Fig. 7a). The values for D. salina were $36.1 \pm 4.72 \%$ and $66.22 \pm 6.02 \%$ for binders S1 and S11 respectively, compared with $14.86 \pm 0.20 \%$ for the suspension controls (Fig. 7b). These were at the upper end of reported lipid contents for both species [51-53]. Photosynthetic conversion efficiencies were calculated for the six weeks trial, ranging between $0.019 \pm 0.002$ and $0.036 \pm 0.001 \%$ (See Table S4). These efficiencies are low (see [54] who report 8-10\% efficiencies) due to the low light levels, modest temperature and non-renewal of nutrients.

\section{Discussion}

Loofah was selected as a candidate 3D scaffold for a low water demand photosynthetic biocomposite for carbon capture applications. Light transmission was not uniform through the loofah, with differences in the percentage loss in PAR affected by the void volumetric space at the centre of the whole loofah allowing greater light penetration per unit depth (Fig. S2). The half loofah therefore had a greater overall strand density (strands $\mathrm{mm}^{-3}$ ) 
relative to the whole loofah in either orientation. It should be noted that these values are based on direct sunlight, whereas the $\mathrm{CO}_{2}$ fixation tests were conducted under artificial light at a considerably lower light intensity (30.5 $\mu \mathrm{mol} \mathrm{m} \mathrm{s}^{-2} \mathrm{~s}^{-1}$. This approximates to light levels of $19.7 \mu \mathrm{mol} \mathrm{m}^{-2} \mathrm{~s}^{-1}$ penetrating to the centre of the loofah in the semi-batch test and $22.7 \mu \mathrm{mol} \mathrm{m}{ }^{-2} \mathrm{~s}^{-1}$ for the continuous $\mathrm{CO}_{2}$ fixation test assuming no additional light loss from the biocoating.

The $\mathrm{CO}_{2}$ absorption rates across the biocomposites were significantly higher than their suspension controls due to a higher $\mathrm{CO}_{2}$ concentration gradient and loofah surface area compared to suspended cultures, even in treatments that experienced a failed replicate. That aside, biocomposite performance was stable across treatments as evidenced by the consistent and tight standard deviations. The biocoatings were applied manually, with between replicate variability largely explained by the extent and lack of uniform coverage of the loofah strands, with some pooling of the biocoating on the less illuminated side of the loofah strand - this could partly be ameliorated using spray application. Typically, $\mathrm{CO}_{2}$ is taken up for photosynthesis by algae and cyanobacteria as bicarbonate $\left(\mathrm{HCO}_{3}^{-}\right)$, although there is evidence of direct $\mathrm{CO}_{2}$ uptake depending on their environmental parameters, taxonomic features, concentration of carbon sources and $\mathrm{pH}$ of culture medium $[55,56]$. The sorbed water via the thin film of coating in the biocomposites should support a steep $\mathrm{CO}_{2}$ concentration gradient and rapid solubility of $\mathrm{CO}_{2}$, allowing efficient uptake by the cells. In contrast, the suspension controls lacked dynamic mixing and relied only on the slow driving force of diffusion which limits mass transfer efficiency as the molecules are required to pass through bulk liquid water before reaching the cells [57]. A similar scenario will exist for $\mathrm{O}_{2}$ outgassing (to prevent photorespiration), with the biocomposites presenting a more efficient system [55, 58, 59]. Additionally, as nutrients were not renewed during the tests, increased $\mathrm{CO}_{2}$ uptake rates could also stem from nutrient limitation [60], as the immobilised cells were reliant upon capillary action via loofah to access the growth medium whereas the suspended cells were permanently bathed in nutrients. This scenario would similarly explain the large differences in lipid content between treatments as nutrient limitation (particularly nitrogen), is a renowned initiator of triglycerides synthesis in microalgae [61].

Based on the semi-batch test data, the biocomposites can theoretically capture $\mathrm{CO}_{2}$ at rates of between $40.47 \pm 1.61$ to $340.11 \pm 110.32 \mathrm{tCO}_{2} \mathrm{t}^{-1}$ biomass $\mathrm{yr}^{-1}$ (Table 1 ). The continuous $\mathrm{CO}_{2}$ test yielded substantive performance gains (ranging from 42 to 127\%), and potentially yielding upwards of $600 \mathrm{~kg}$ of lipids; however, we lack comparative data for the cyanobacteria (the best performing biocomposites under semi-batch testing conditions). If we assume similar relative performance gains, then S. elongatus under continuous exposure could potentially scale to between 350.7 and $560.6 \mathrm{tCO}_{2} \mathrm{t}^{-1}$ biomass $\mathrm{yr}^{-1}$ for PCC 7942 and 483 and $776.6 \mathrm{tCO}_{2} \mathrm{t}^{-1}$ biomass $\mathrm{yr}$ 
${ }^{1}$ for CCAP 1479/1A, although the lower lipid biosynthesis capability of S. elongatus would limit lipid yields to approximately $110 \mathrm{~kg}$ [62]. Thus, other end products made up of carbohydrates or protein should be targeted instead of lipid for S. elongatus biocomposites.

It is challenging to compare the current study with other microalgae-based carbon capture technologies, due to a lack of standardised conditions between experiments, coupled with variation in the reported metrics (Table 5). The majority of studies have been conducted with suspension cultures at various scales, with few using a biocomposite or biofilm approach. Our data compare favourably with studies that report $\mathrm{CO}_{2}$ fixation as $\mathrm{g} \mathrm{CO}_{2}$ $\mathrm{g}^{-1}$ biomass $\mathrm{d}^{-1}$. However, the fixation rates achieved with $S$. elongatus biocomposites were 20 times lower than Bernal et al.'s paper-based acrylate copolymer latex coating biocomposites with immobilised S. elongatus PCC 7002 [28]. This is likely due to cell loading differences; $2.5 \%$ versus $50 \%$ v/v, i.e. a 20 -fold difference. Vaz et al. [63] used the initial dry weight biomass of $0.23 \mathrm{~g}$ to cultivate Chlorella fusca on polymeric nanofibers whereas we used $0.05 \mathrm{~g}$ of $C$. vulgaris for the continuous $\mathrm{CO}_{2}$ absorption test. The net $\mathrm{CO}_{2}$ fixation rate achieved from their study was $0.27 \mathrm{~g} \mathrm{CO}_{2} \mathrm{~g}^{-1} \mathrm{~d}^{-1}$ which is broadly comparable to our $C$. vulgaris + binder $\mathrm{S} 3$ data $\left(0.17 \pm 0.01 \mathrm{~g} \mathrm{CO}_{2}\right.$ $\mathrm{g}^{-1} \mathrm{~d}^{-1}$ ). It should be noted that we assume that the binder application is perfectly efficient, i.e. that all cells in the biocoating are immobilised to the loofah. In reality, some cells are lost to waste by our current coating technique forming non-uniform coating thickness in the biocomposite structure. Therefore, the $\mathrm{CO}_{2}$ fixation rates per $\mathrm{g}$ biomass will be underestimated. Improvements may therefore be made by increasing cell loading (i.e. using a denser biocoating); however, Flickinger et al. [64] mentioned that a threshold cell loading for latex binders (as yet undefined, and likely species and binder specific) should not be exceeded as it may compromise porosity and adhesion. Further, substantially increased cell loading may compromise performance through excessive competition for water, light, nutrients and $\mathrm{CO}_{2}$. A recent study suggested that it is possible to increase the porosity of the latex to produce stable biocoating using non-toxic non-film forming nanoparticles [65]; offering a potential route to improve the performance of our biocomposite systems.

There were few significant cell releases from the biocomposites during the semi-batch $\mathrm{CO}_{2}$ testing with synthetic latex binders (Fig. S14). C. vulgaris and N. oculata remained within the binders (Fig. S14c\&i), although the D. salina biocomposite (Fig. S14f) did display some pitting from cell loss (possibly during the drying process). However, most cells of both cyanobacteria strains grew out of the bio-latex binders after four weeks into the growth medium (see Fig. S15). During the continuous $\mathrm{CO}_{2}$ test it was $N$. oculata rather than D. salina that experienced adhesion and retention issues. The loss of cells to the liquid growth medium in both tests would have 
reduced the overall $\mathrm{CO}_{2}$ fixation if the released cells reverted to a photosynthetic rate equivalent to the suspension controls.

Conditions inside the sample vials during the tests may have compromised binder integrity as the biocomposites were continuously exposed to moisture that may have altered their adhesive properties [66]. For the cyanobacteria, the bio-latex appeared to enhance the growth rate as previously observed in the toxicity test (Fig. S10d-e), with the growing biomass leading to partial binder failure and release of the cells. This observation poses something of a paradox for mass microalgae/cyanobacteria production systems. Ordinarily, open ponds and PBRs are designed to maximise biomass production by delivering optimised growth conditions; however, rapid biomass production may be suboptimal for immobilised systems. For biocomposites, an unusual 'maintenance of viability' approach is warranted whereby the nutrient system must deliver conditions supportive of active metabolism but sufficiently suboptimal to slow or even eliminate cell division [64], such as has been achieved for Escherichia coli [67], Rhodopseudomonas palustris [68] and Gluconobacter oxydans [69]. When combining cells with binders, it appeared to initiate a cell morphology change for S. elongatus, transiting from a rod-shaped to a coccoid form (Fig. S16). The implications of this for immobilised cultivation are unknown; however, similar observations have been made for $S$. elongatus and other bacteria with suggestions that the behaviour may regulate photosynthesis and cell division under stress $[40,70,71]$.

The findings from the semi-batch tests appear to show that the cells are covered with a thin polymer layer which protects the cells. The cell retention capabilities of many of the latex binders should stimulate future biocomposite coating technology exploration, including expanding the use of microalgae 'milking' to recover biochemicals (including lipids) without permanently compromising cell health [72], and specifically as a platform for the adoption and safe environmental deployment of metabolically engineered microorganisms for industrial and environmental applications $[73,74]$. On a similar note, the species assayed in this study are evolved for a planktonic existence (i.e. living in suspension in the water column). The immobilisation process compels the cells to live in a film, i.e. to become benthic — a living state for which they may be genetically ill-equipped. As indicated, the cyanobacteria responded by changing their cell morphology. Options exist to metabolically engineer the organisms whereby the transition from planktonic to benthic lifestyles may be routine as has previously been done for S. elongatus [75-77], or they may be engineered for improved adhesive capabilities as reported for $E$. coli $[78,79]$. Equally, synthetic biology approaches could be used to address resource limitation effects, such as combating self-shading [80]. On the theme of entraining planktonic cells to a forced benthic existence, future work may also wish to explore natural biofilm forming species as candidates for biocomposite manufacture, as 
many such species naturally synthesise extracellular polymeric substances (EPS) that support adhesion and biofilm integrity $[81,82]$. However, to sound a note of caution, many such species also utilise EPS as a biolubricant to aid gliding motility (c.f. many raphid diatoms) which could act to breakdown the biocomposite. In such instances the need for a robust binder may be even greater, although we have previously observed that a raphid pennate diatom (Navicula pelliculosa; In-na and Caldwell, unpublished) readily escapes binders by exploiting EPS to reduce adhesion. Additional complications may arise with natural biofilm formers, as dispersion is an intrinsic part of a biofilm cycle, particularly in response to nutrient stress [83, 84]. Such a scenario could lead to epidemic biocomposite failure. EPS could also provide a ready substrate for bacterial growth which may compromise the health and longevity of the biocomposite. Whilst the use of planktonic species may seem counterintuitive, there are compelling arguments why they may have fewer operational problems that natural biofilm forming taxa.

In this study, we developed microalgae and cyanobacteria based biocomposites for carbon capture over sustained durations, utilising loofah sponge as a cheap and sustainable scaffold. Cell immobilisation greatly enhanced net $\mathrm{CO}_{2}$ fixation relative to suspension controls, with most biocomposites showing little or no reduction in performance. The cyanobacteria biocomposites significantly outperformed their microalgae comparators; however, this may be due to either the greater surface area of cells in cyanobacteria biocomposites or the differing binders used between the groups (petroleum-based synthetic binders for microalgae versus bio-based binders for the cyanobacteria). The microalgae also had a high lipid content compared to their suspension controls, potentially opening loofah based biocomposites for applications in bioenergy with carbon capture and storage (BECCS). These 3D coated biocomposites overcome some of the disadvantages of open pond and photobioreactor growth systems, particularly in terms of water consumption. Further optimisation is required to increase $\mathrm{CO}_{2}$ absorption, for example by increasing cell loading, reducing the mass transfer resistance of the polymer layer over the cells and conducting tests under high PAR intensity sunlight rather than low intensity artificial light. With further improvements, including metabolic engineered systems, it may not be unreasonable to predict that loofah based biocomposites (particularly with cyanobacteria) could capture in the region of $1000 \mathrm{tCO}_{2} \mathrm{t}^{-1}$ biomass $\mathrm{yr}^{-1}$.

\section{Author contributions}

The study was conceived by all authors. Data were collected by AU, PI and AW and analysed by AU, PI, AW, GC and JL. The manuscript was written by AU, PI, GC and JL, and edited and approved by AW and MF. 
499 Compliance with ethical standards

Funding: This study was funded by the National Science Foundation CBET (grant no. 1510072) and the Petroleum Technology Development Fund, Nigeria.

Conflict of Interest: Abbas A. Umar declares that he has no conflict of interest. Pichaya In-na declares that she has no conflict of interest. Adam D. Wallace declares that he has no conflict of interest. Michael C. Flickinger declares that he has no conflict of interest. Gary S. Caldwell declares that he has no conflict of interest. Jonathan G.M. Lee declares that he has no conflict of interest.

Ethical approval: This article does not contain any studies with human participants or animals performed by any of the authors.

\section{Figure legends}

Fig. 1 Decision matrix derived from toxicity and adhesion data for (a) C. vulgaris, (b) D. salina, (c) N. oculata, (d) S. elongatus PCC 7942 and (e) CCAP 1479/1A. Refer to Tables S1 and S2 for binder details.

Fig. 2 SEM images of a representative loofah scaffold (a) before and (b) after cell immobilisation with effective and (c) ineffective synthetic binders. Magnification: 40x.

Fig. 3 SEM images of S. elongatus CCAP 1479/1 A biocomposites before and after adhesion testing. Red boxes indicate where the cells were immobilised with binders. Binder B4 exhibiting poor cell retention (before $=\mathrm{a} \& \mathrm{c}$, after $=\mathrm{b} \& d)$, binder B5 exhibiting good cell retention $($ before $=\mathrm{e} \& \mathrm{~g}$, after $=\mathrm{f} \& \mathrm{~h})$. Magnification: $4000 \times(\mathrm{a}, \mathrm{b}, \mathrm{e}$, f) and $9000 \times(c, d, g, h)$.

Fig. 4 Cumulative net $\mathrm{CO}_{2}$ fixation (mean $\pm \mathrm{StDev}$ ) of (a) C. vulgaris, (b) D. salina, (c) N. oculata and (d) $S$. elongatus biocomposites compared with their suspension culture controls from the eight weeks semi-batch $\mathrm{CO}_{2}$ fixation test.

Fig. 5 Comparison of the volumeric $\mathrm{CO}_{2}$ transfer coefficients for suspended and biocomposite cultures of cyanobacteria and microalgae.

Fig. 6 Cumulative net $\mathrm{CO}_{2}$ fixation (mean $\pm \mathrm{StDev}$ ) of (a) C. vulgaris, (b) D. salina, and (c) N. oculata biocomposites compared with their suspension culture controls from the six weeks continuous $\mathrm{CO}_{2}$ fixation test.

Fig. 7 Percentage biomass lipid content (dry weight) (mean \pm StDev) of (a) C. vulgaris and (b) D. salina biocomposites compared with their suspension culture controls at the end of the six weeks continuous $\mathrm{CO}_{2}$ fixation test. 
Page 19 of 35 
Table 1 Net semi-batch $\mathrm{CO}_{2}$ fixation rates (mean $\pm \mathrm{StDev}$ ) for the best performing biocomposite for each species

530 compared with their suspension culture controls: $C$. vulgaris $+\mathrm{S} 1 ;$ D. salina $+\mathrm{S} 11 ;$ N. oculata $+\mathrm{S} 4 ;$ S. elongatus

531 PCC 7942 + B6; CCAP 1479/1A + B5. Data are presented in a range of formats to better enable comparison with

532 other published studies. A theoretical scaled $\mathrm{CO}_{2}$ capture (as tonne $\mathrm{CO}_{2}$ captured per tonne of biomass per year)

533 from an up-scaled version of the biocomposite system is also presented.

\begin{tabular}{|c|c|c|c|c|c|c|}
\hline \multirow[b]{2}{*}{ Phototroph } & \multicolumn{5}{|c|}{ Net $\mathrm{CO}_{2}$ fixation rates } & \multirow{2}{*}{$\begin{array}{l}\text { Theoretical } \\
\text { scaled } \mathrm{CO}_{2} \\
\text { capture }\left(\mathrm{tCO}_{2}\right. \\
\left.\mathrm{t}^{-1} \text { biomass } \mathrm{yr}^{-1}\right)\end{array}$} \\
\hline & $\begin{array}{l}\text { Suspension } \\
\left(\mathrm{mmol} \mathrm{CO}_{2}\right. \\
\left.\mathrm{g}^{-1} \text { biomass } \mathrm{d}^{-1}\right)\end{array}$ & $\begin{array}{l}\text { Biocomposite } \\
\left(\mathrm{mmol} \mathrm{CO}_{2} \mathrm{~g}^{-}\right. \\
\left.{ }^{1} \text { biomass } \mathrm{d}^{-1}\right)\end{array}$ & $\begin{array}{l}\text { Biocomposite } \\
\left(\mathrm{mmol} \mathrm{CO}_{2}\right. \\
\left.\mathrm{m}^{-2} \mathrm{~d}^{-1}\right)\end{array}$ & $\begin{array}{l}\text { Biocomposite } \\
\left(\mathrm{g} \mathrm{CO}_{2} \mathrm{~m}^{-2} \mathrm{~d}^{-}\right. \\
\left.{ }^{1}\right)\end{array}$ & $\begin{array}{l}\text { Biocomposite } \\
\left(\mathrm{g} \mathrm{CO}_{2} \mathrm{~g}^{-1}\right. \\
\left.\text { biomass } \mathrm{d}^{-1}\right)\end{array}$ & \\
\hline C. vulgaris & $0.92 \pm 0.03$ & $2.52 \pm 0.10$ & $4.66 \pm 0.18$ & $0.20 \pm 0.01$ & $0.11 \pm 0.01$ & $40.47 \pm 1.61$ \\
\hline D. salina & $0.40 \pm 0.06$ & $2.99 \pm 0.41$ & $5.53 \pm 0.76$ & $0.24 \pm 0.03$ & $0.13 \pm 0.02$ & $48.01 \pm 6.58$ \\
\hline N. oculata & $0.48 \pm 0.05$ & $2.71 \pm 0.24$ & $5.01 \pm 0.44$ & $0.22 \pm 0.02$ & $0.12 \pm 0.01$ & $43.52 \pm 3.85$ \\
\hline $\begin{array}{l}\text { S. elongatus } \\
\text { PCC } 7942\end{array}$ & $1.77 \pm 0.03$ & $15.38 \pm 4.06$ & $7.72 \pm 2.04$ & $0.34 \pm 0.09$ & $0.68 \pm 0.18$ & $\begin{array}{l}246.97 \pm \\
65.20\end{array}$ \\
\hline $\begin{array}{l}\text { S. elongatus } \\
\text { CCAP } \\
\text { 1479/1A }\end{array}$ & $2.08 \pm 0.13$ & $21.18 \pm 6.87$ & $6.15 \pm 2.00$ & $0.27 \pm 0.09$ & $0.93 \pm 0.30$ & $\begin{array}{l}340.11 \pm \\
110.32\end{array}$ \\
\hline
\end{tabular}


Table 2 Comparison of the volumetric $\mathrm{CO}_{2}$ transfer coefficents for suspended culture and the biocomposites.

\begin{tabular}{|c|c|c|c|c|c|c|}
\hline \multirow[b]{2}{*}{ Phototroph } & \multirow{2}{*}{$\begin{array}{c}\text { Cell surface } \\
\text { area } \\
\left(\mathrm{m}^{2} \times 10^{11}\right)\end{array}$} & \multirow[b]{2}{*}{$\mathrm{N}_{\text {cell }} \times 10^{-7}$} & \multicolumn{2}{|c|}{ Suspended culture } & \multicolumn{2}{|c|}{ Biocomposite } \\
\hline & & & $\begin{array}{c}\mathrm{ac}_{\mathrm{C}} \\
\left(\mathrm{m}^{2} \mathrm{~m}^{-3}\right)\end{array}$ & $\begin{array}{c}\mathrm{K} \mathrm{ac} \\
\left(\mathrm{s}^{-1} \times 10^{6}\right)\end{array}$ & $\begin{array}{c}\mathrm{ac}_{\mathrm{C}} \\
\left(\mathrm{m}^{2} \mathrm{~m}^{-3}\right)\end{array}$ & $\begin{array}{c}\mathrm{K} \mathrm{a}_{\mathrm{C}} \\
\left(\mathrm{s}^{-1} \times 10^{6}\right)\end{array}$ \\
\hline $\begin{array}{l}\text { S. elongatus } \\
{\text { PCC } 7942^{\text {a }}}^{\text {a }}\end{array}$ & 2.15 & 3160 & 128060 & $14.6 \pm 0.7$ & 135744 & $5.4 \pm 0.5$ \\
\hline $\begin{array}{l}\text { S. elongatus } \\
\text { CCAP } \\
1479 / 1 \mathrm{~A}^{\mathrm{b}}\end{array}$ & 1.26 & 4490 & 106458 & $62.7 \pm 1.1$ & 112846 & $5.9 \pm 0.6$ \\
\hline C. vulgaris & $7.85-31.4$ & $0.59-5.14$ & $920-2016$ & $6.3 \pm 5.3$ & $921-2019$ & $2.4 \pm 0.5$ \\
\hline D. salina & $80.4-181$ & $0.044-0.16$ & $397-635$ & $2.7 \pm 2.5$ & $397-637$ & $1.6 \pm 0.1$ \\
\hline N. oculata & $1.26-5.03$ & $9.50-81.1$ & $2383-5088$ & $3.7 \pm 2.9$ & $2386-5098$ & $2.0 \pm 0.2$ \\
\hline
\end{tabular}

$537 \mathrm{a}-$ Calculated from rod-shaped cells with an assumption that all cells had a diameter and length of 2 and $4 \mu \mathrm{m}$.

$538 \mathrm{~b}-$ Calculated from coccoid cells with an assumption that all the cells had a diameter of $2 \mu \mathrm{m}$. 
Table 3 Values of the binder film diffusivity calculated from experimental transfer coefficients.

\begin{tabular}{|c|c|c|c|c|}
\hline Phototroph & $\begin{array}{c}\mathrm{k}_{\mathrm{cell}} \\
\left(\mathrm{m} \mathrm{s}^{-1} \times 10^{10}\right)\end{array}$ & $\begin{array}{c}\mathrm{k}_{\mathrm{BC}} \\
\left(\mathrm{m} \mathrm{s}^{-1} \times 10^{10}\right)\end{array}$ & $\begin{array}{c}\mathrm{K}_{\text {binder }} \\
\left(\mathrm{m} \mathrm{s}^{-1} \times 10^{10}\right)\end{array}$ & $\begin{array}{c}\mathrm{D}_{\mathrm{B}} \\
\left(\mathrm{m}^{2} \mathrm{~s}^{-1} \times 10^{15}\right)\end{array}$ \\
\hline S. elongatus PCC 7942 & 1.1 & 0.39 & 0.60 & 1.6 \\
\hline S. elongatus CCAP 1479/1A & 5.9 & 0.52 & 0.57 & 1.5 \\
\hline C. vulgaris & 50 & 19 & 31 & 80 \\
\hline D. salina & 55 & 32 & 75 & 200 \\
\hline N. oculata & 11 & 6.2 & 14 & 35 \\
\hline
\end{tabular}

541

542

543

544

545

546 
Table 4 Net continuous $\mathrm{CO}_{2}$ fixation rates (mean \pm StDev) for each biocomposite for $C$. vulgaris and D. salina compared with their suspension culture controls. A theoretical scaled $\mathrm{CO}_{2}$ capture (as tonne $\mathrm{CO}_{2}$ captured per tonne of biomass per year) from an up-scaled version of the biocomposite system is also presented.

\begin{tabular}{|c|c|c|c|c|c|c|}
\hline \multirow{2}{*}{ Biocomposite } & \multicolumn{5}{|c|}{ Net $\mathrm{CO}_{2}$ fixation rates } & \multirow{2}{*}{$\begin{array}{l}\text { Theoretical } \\
\text { scaled } \mathrm{CO}_{2} \\
\text { capture }\left(\mathrm{tCO}_{2} \mathrm{CO}_{2}\right. \\
\left.\mathrm{t}^{-1} \text { biomass } \mathrm{yr}^{-1}\right)\end{array}$} \\
\hline & $\begin{array}{l}\text { Suspension } \\
\left(\mathrm{mmol} \mathrm{CO}_{2}\right. \\
\left.\mathrm{g}^{-1} \text { biomass } \mathrm{d}^{-1}\right)\end{array}$ & $\begin{array}{l}\text { Biocomposite } \\
\left(\mathrm{mmol} \mathrm{CO}_{2}\right. \\
\left.\mathrm{g}^{-1} \text { biomass } \mathrm{d}^{-1}\right)\end{array}$ & $\begin{array}{l}\text { Biocomposite } \\
\left(\mathrm{mmol} \mathrm{CO}_{2}\right. \\
\left.\mathrm{m}^{-2} \mathrm{~d}^{-1}\right)\end{array}$ & $\begin{array}{l}\text { Biocomposite } \\
\left(\mathrm{g} \mathrm{CO}_{2} \mathrm{~m}^{-2} \mathrm{~d}^{-}\right. \\
\left.{ }^{1}\right)\end{array}$ & $\begin{array}{l}\text { Biocomposite } \\
\left(\mathrm{g} \mathrm{CO}_{2} \mathrm{~g}^{-1}\right. \\
\left.\text { biomass } \mathrm{d}^{-1}\right)\end{array}$ & \\
\hline C. vulgaris + & \multirow{3}{*}{$0.65 \pm 0.02$} & $3.93 \pm 0.16$ & $2.38 \pm 0.10$ & $0.10 \pm 0.01$ & $0.17 \pm 0.01$ & $63.11 \pm 2.57$ \\
\hline S3 & & & & & & \\
\hline C. vulgaris + & & $3.58 \pm 0.50$ & $2.17 \pm 0.30$ & $0.10 \pm 0.01$ & $0.16 \pm 0.02$ & $57.49 \pm 8.03$ \\
\hline \multicolumn{7}{|l|}{ S1 } \\
\hline D. salina $+\mathrm{S} 11$ & \multirow{2}{*}{$0.32 \pm 0.05$} & $5.69 \pm 0.24$ & $3.44 \pm 0.15$ & $0.15 \pm 0.01$ & $0.25 \pm 0.01$ & $91.37 \pm 3.85$ \\
\hline D. salina $+\mathrm{S} 1$ & & $4.31 \pm 0.67$ & $2.61 \pm 0.40$ & $0.11 \pm 0.02$ & $0.19 \pm 0.03$ & $69.21 \pm 41.91$ \\
\hline
\end{tabular}


Table 5 Comparison of the highest $\mathrm{CO}_{2}$ fixation rates for semi-batch and continuous tests relative to selected

557 literature values, including the model species Arabidopsis thaliana as a reference plant. We made approximate calculations and conversions based on the information available if data were not explicitly stated within a paper in an appropriate form.

\begin{tabular}{|c|c|c|c|c|c|}
\hline \multirow[t]{2}{*}{ Species and strain } & \multirow[t]{2}{*}{ Type } & \multirow[t]{2}{*}{ System description } & \multicolumn{2}{|c|}{$\mathrm{CO}_{2}$ fixation rate } & \multirow[t]{2}{*}{ Ref } \\
\hline & & & $\begin{array}{l}(\mathrm{mmol} \mathrm{CO} 2 \\
\left.\mathrm{m}^{-2} \mathrm{~d}^{-1}\right)\end{array}$ & $\begin{array}{l}\left(\mathrm{g} \mathrm{CO}_{2} \mathrm{~g}^{-1}\right. \\
\left.\text { biomass } \mathrm{d}^{-1}\right)\end{array}$ & \\
\hline $\begin{array}{l}\text { Arabidopsis } \\
\text { thaliana (wild type) }\end{array}$ & Angiosperm & $\begin{array}{l}\text { Open gas exchange } \\
\left.\text { chamber (ambient } \mathrm{CO}_{2}\right) \text { at } \\
25^{\circ} \mathrm{C} \text {; light: } 300 \mu \mathrm{mol} \mathrm{m}^{-2} \\
\mathrm{~s}^{-1}\end{array}$ & 432 & 0.25 & [85] \\
\hline $\begin{array}{l}\text { Monoraphidium } \\
\text { dybowskii LB50 }\end{array}$ & $\begin{array}{l}\text { Freshwater } \\
\text { chlorophyte }\end{array}$ & $\begin{array}{l}200 \mathrm{~m}^{2} \text { open raceway at } \\
\text { ambient temperature and } \\
\mathrm{CO}_{2}\end{array}$ & 750 & 0.37 & {$[40]$} \\
\hline $\begin{array}{l}\text { Synechococcus } \\
\text { PCC7002 }\end{array}$ & Cyanophyte & $\begin{array}{l}\text { Paper-based biocomposites } \\
\text { with } 20 \% \mathrm{v} / \mathrm{v} \mathrm{CO}_{2} \text { at } 25 \\
{ }^{\circ} \mathrm{C} \text {; light: } 100 \mu \mathrm{mol} \mathrm{m}^{-2} \mathrm{~s}^{-1}\end{array}$ & 136 & 0.22 & {$[28]$} \\
\hline $\begin{array}{l}\text { Oedogonium } \\
\text { crispum }\end{array}$ & $\begin{array}{l}\text { Freshwater } \\
\text { chlorophyte } \\
\text { (macroalgae) }\end{array}$ & $\begin{array}{l}15,000 \mathrm{~L} \text { culture tank at } \\
\text { ambient temperature, } \mathrm{CO}_{2} \\
\text { enriched regulated by } \\
\text { culture pH; light: } 230 \\
\mu \mathrm{mol} \mathrm{m} \mathrm{m}^{-2} \mathrm{~s}^{-1}\end{array}$ & 85 & 0.45 & {$[86]$} \\
\hline $\begin{array}{l}\text { Chlorella fusca } \\
\text { LEB } 111\end{array}$ & $\begin{array}{l}\text { Freshwater } \\
\text { chlorophyte }\end{array}$ & $\begin{array}{l}\text { Cultivated on } \mathrm{CO}_{2} \\
\text { adsorbent nanofibers in } \\
0.45 \mathrm{~L} \mathrm{PBR} \text { at } 25^{\circ} \mathrm{C} \text {; light: } \\
41.6 \mu \mathrm{mol} \mathrm{m} \mathrm{m}^{-2}\end{array}$ & - & 0.27 & {$[63]$} \\
\hline C. vulgaris & $\begin{array}{l}\text { Freshwater } \\
\text { chlorophyte }\end{array}$ & $\begin{array}{l}15 \mathrm{~L} \text { tubular reactor at } \\
25^{\circ} \mathrm{C} \text { with continuous } 8 \% \\
\text { v/v } \mathrm{CO}_{2}\left(1001 \mathrm{~h}^{-1}\right) ; \text { light: } \\
\text { >twice daylight }\end{array}$ & - & 0.91 & [87] \\
\hline $\begin{array}{l}\text { Nannochloropsis } \\
\text { gaditana }\end{array}$ & $\begin{array}{l}\text { Marine } \\
\text { ochrophyte }\end{array}$ & $\begin{array}{l}1.5 \mathrm{~L} \text { tubular reactor at } \\
25^{\circ} \mathrm{C} \text { with continuous } 8 \% \\
\text { v/v } \mathrm{CO}_{2}\left(1001 \mathrm{~h}^{-1}\right) ; \text { light: } \\
\text { >twice daylight }\end{array}$ & - & 1.61 & [87] \\
\hline $\begin{array}{l}\text { S. elongatus CCAP } \\
1479 / 1 \mathrm{~A}\end{array}$ & Cyanophyte & 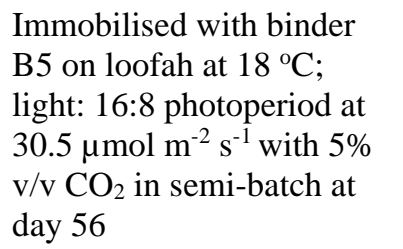 & 6.15 & 0.93 & $\begin{array}{l}\text { This } \\
\text { study }\end{array}$ \\
\hline Dunaliella salina & $\begin{array}{l}\text { Marine } \\
\text { chlorophyte }\end{array}$ & 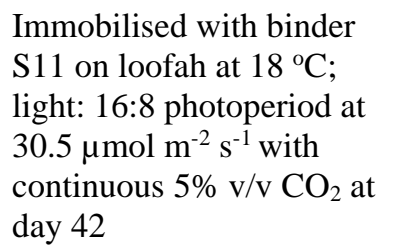 & 3.44 & 0.25 & $\begin{array}{l}\text { This } \\
\text { study }\end{array}$ \\
\hline
\end{tabular}



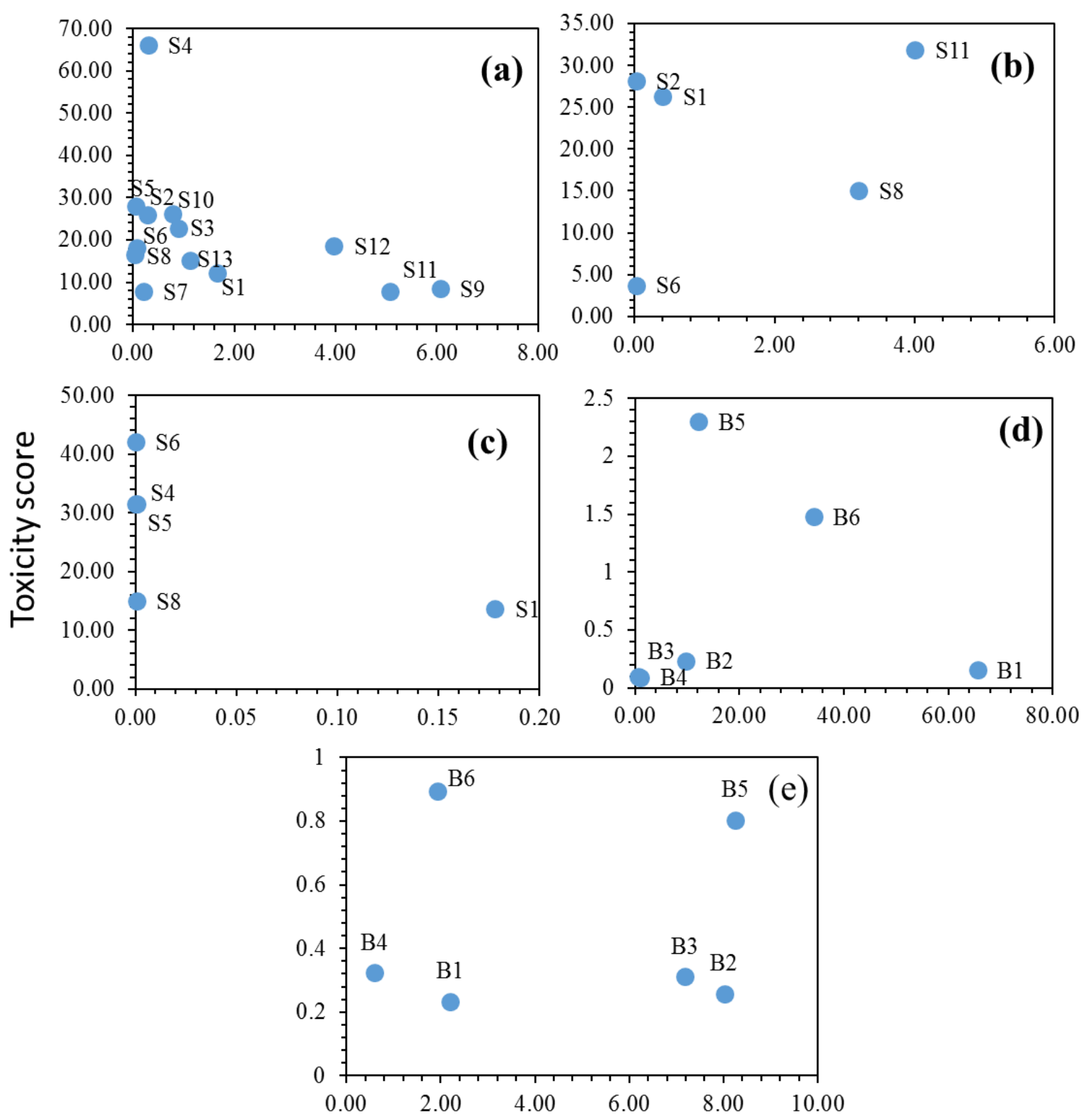

Adhesion score 


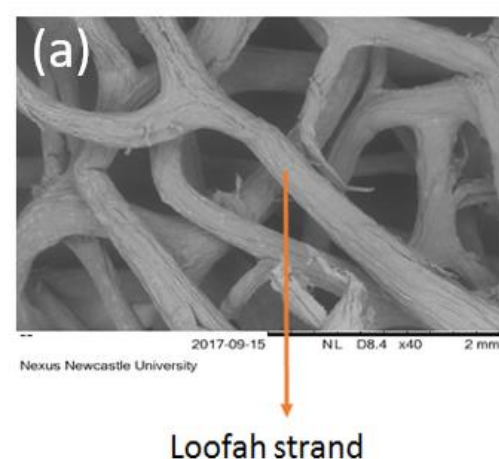

567

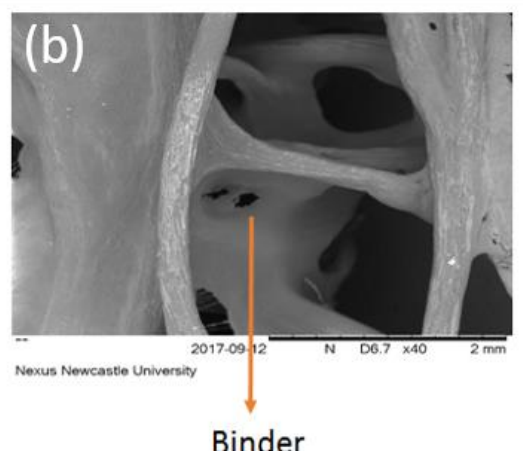

Fig 2

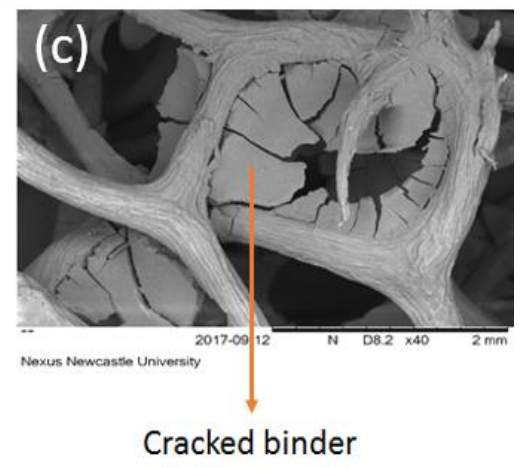

Cracked binder 


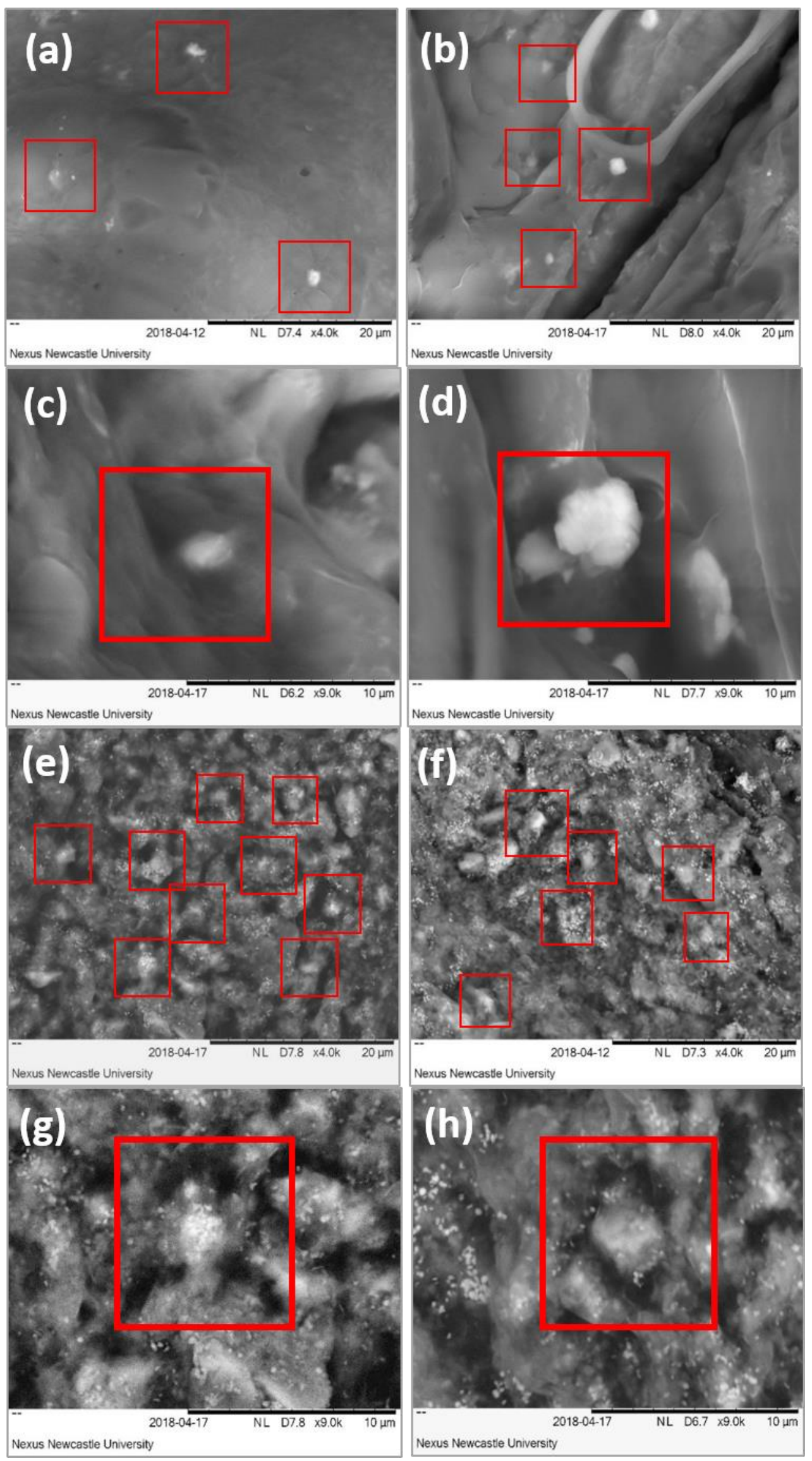

Fig 3 

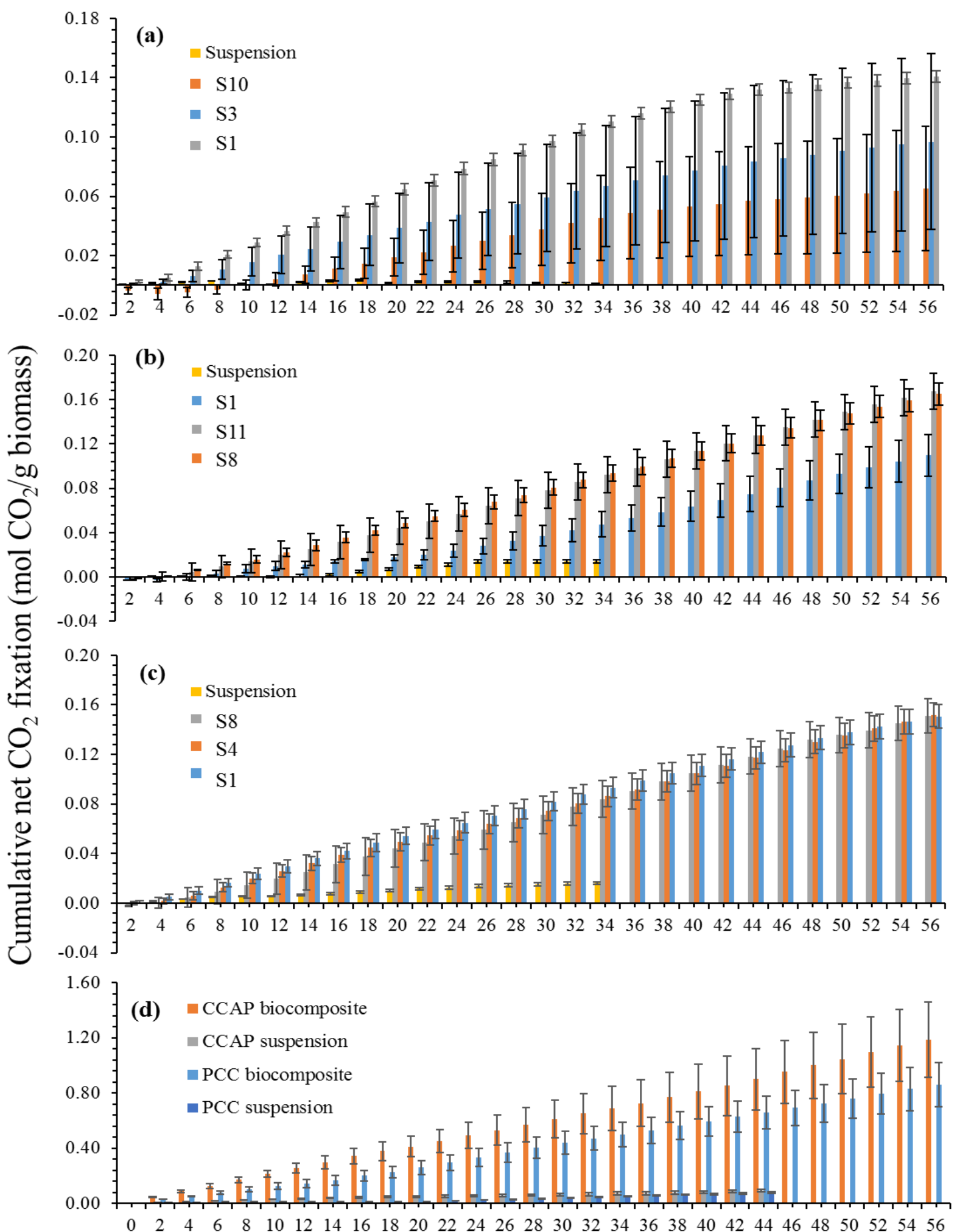

Time (Day) 


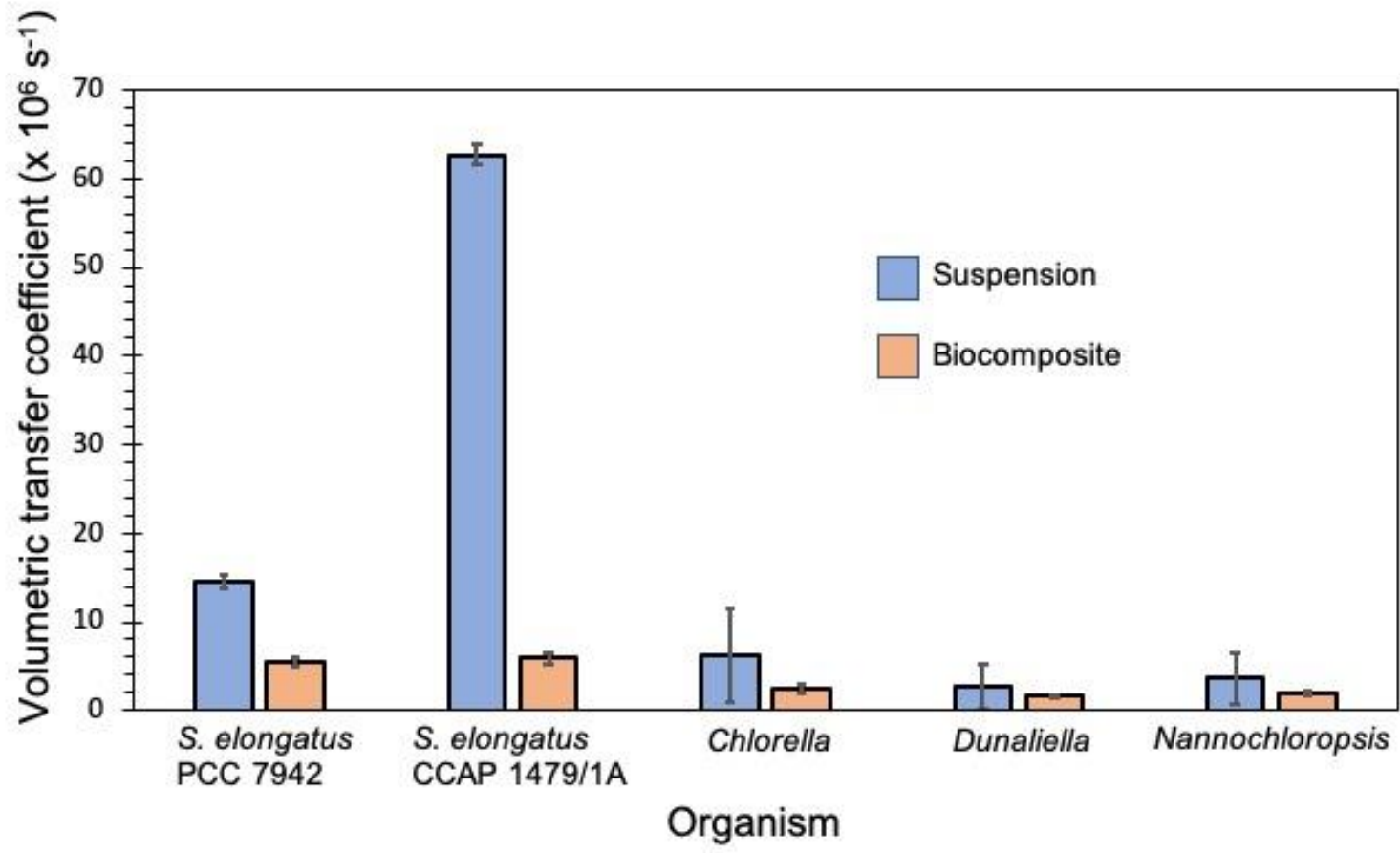

574

575

Fig 5

577 


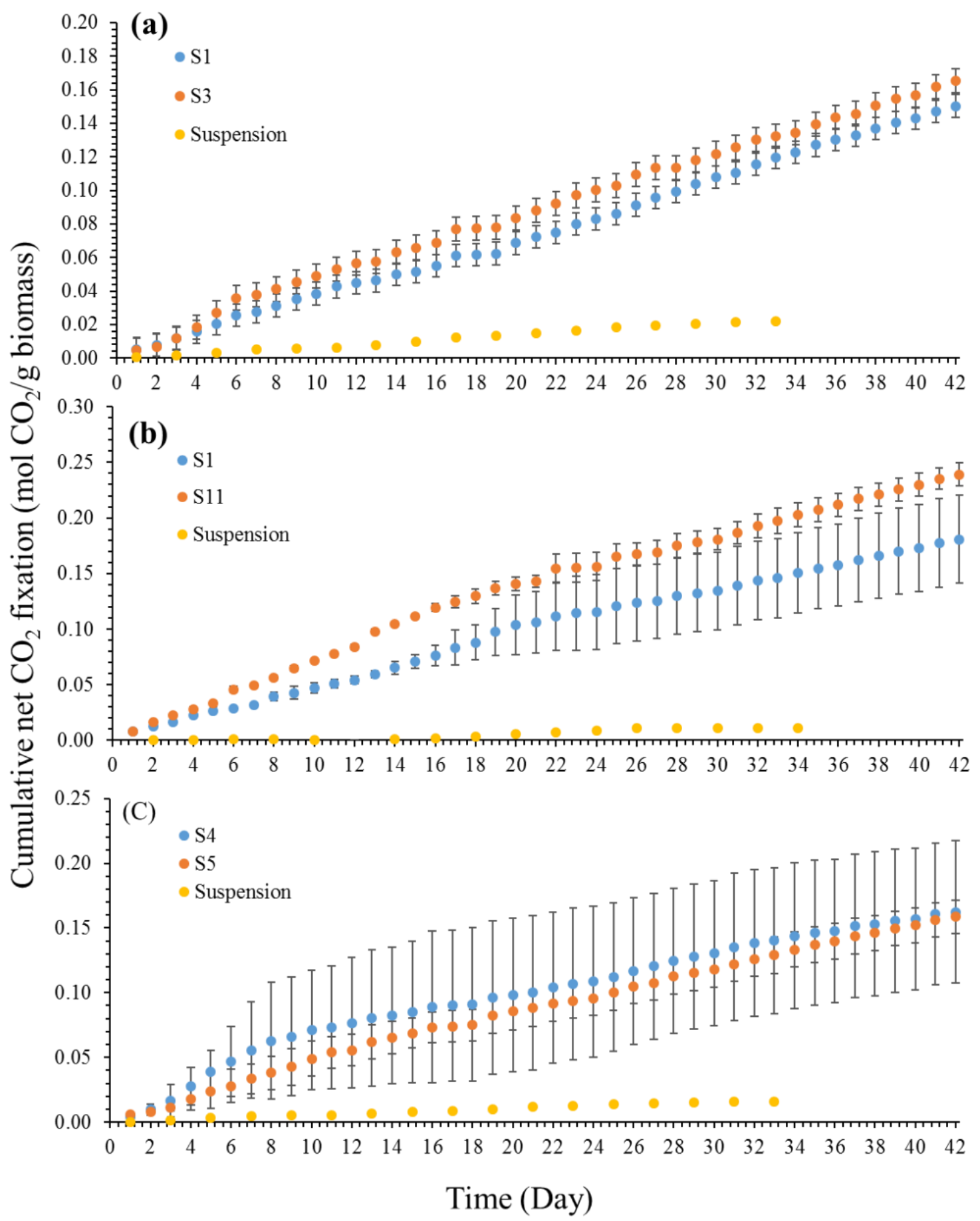

579

Fig 6 

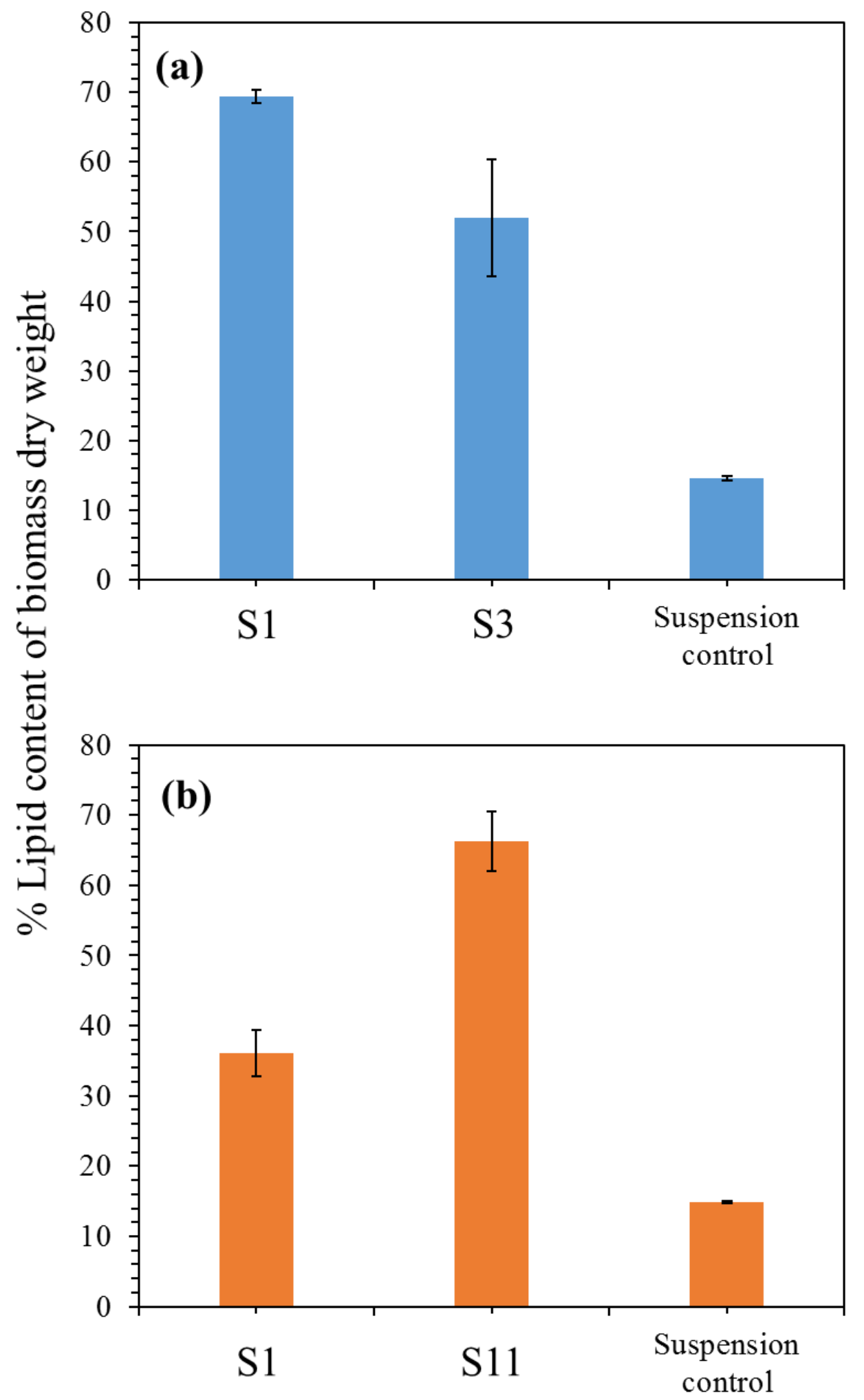

Treatment

Fig 7 
[1] R.M. Cuéllar-Franca, A. Azapagic, Carbon capture, storage and utilisation technologies: A critical analysis and comparison of their life cycle environmental impacts, J. $\mathrm{CO}_{2}$ Util. 9 (2015) 82102.https://doi.org/10.1016/j.jcou.2014.12.001.

[2] D.Y.C. Leung, G. Caramanna, M.M. Maroto-Valer, An overview of current status of carbon dioxide capture and storage technologies, Renew. Sust. Energ. Rev. 39 (2014) 426-443.https://doi.org/10.1016/j.rser.2014.07.093. [3] R. Stuart Haszeldine, Carbon capture and storage: how green can black be?, Science 325(5948) (2009) 16471652.https://doi.org/10.1126/science.1172246.

[4] T. Wilberforce, A. Baroutaji, B. Soudan, A.H. Al-Alami, A.G. Olabi, Outlook of carbon capture technology and challenges, Sci. Total Environ. 657 (2019) 56-72.https://doi.org/10.1016/j.scitotenv.2018.11.424.

[5] E.J. Kim, R.L. Siegelman, H.Z.H. Jiang, A.C. Forse, J.-H. Lee, J.D. Martell, P.J. Milner, J.M. Falkowski, J.B. Neaton, J.A. Reimer, S.C. Weston, J.R. Long, Cooperative carbon capture and steam regeneration with tetraamine-appended metal-organic frameworks, $\quad$ Science $\quad 369(6502) \quad$ (2020) 392.https://doi.org/10.1126/science.abb3976.

[6] D. Mantzalis, N. Asproulis, D. Drikakis, Enhanced carbon dioxide adsorption through carbon nanoscrolls, Phys Rev E Stat Nonlin Soft Matter Phys 84(6 Pt 2) (2011) 066304.https://doi.org/10.1103/PhysRevE.84.066304. [7] A.M. Wolsky, E.J. Daniels, B.J. Jody, $\mathrm{CO}_{2}$ capture from the flue gas of conventional fossil-fuel-fired power plants, Environ. Prog. 13(3) (1994) 214-219.https://doi.org/10.1002/ep.670130320.

[8] F.M. Baena-Moreno, M. Rodríguez-Galán, F. Vega, B. Alonso-Fariñas, L.F. Vilches Arenas, B. Navarrete, Carbon capture and utilization technologies: a literature review and recent advances, Energ. Source Part A. 41(12) (2019) 1403-1433.https://doi.org/10.1080/15567036.2018.1548518.

[9] P. Markewitz, W. Kuckshinrichs, W. Leitner, J. Linssen, P. Zapp, R. Bongartz, A. Schreiber, T.E. Müller, Worldwide innovations in the development of carbon capture technologies and the utilization of $\mathrm{CO}_{2}$, Energy Environ. Sci. 5(6) (2012) 7281-7305.https://doi.org/10.1039/c2ee03403d.

[10] J. Singh, D.W. Dhar, Overview of carbon capture technology: Microalgal biorefinery concept and state-ofthe-art, Front. Mar. Sci. 6 (2019).29. https://doi.org/10.3389/fmars.2019.00029.

[11] R.R.P. Noble, L. Stalker, S.A. Wakelin, B. Pejcic, M.I. Leybourne, A.L. Hortle, K. Michael, Biological monitoring for carbon capture and storage - A review and potential future developments, Int. J. Greenh. Gas Con. 10 (2012) 520-535.https://doi.org/10.1016/j.ijggc.2012.07.022.

[12] M. Mondal, S. Khanra, O.N. Tiwari, K. Gayen, G.N. Halder, Role of carbonic anhydrase on the way to biological carbon capture through microalgae-A mini review, Environ. Prog. Sustain. 35(6) (2016) 16051615.https://doi.org/10.1002/ep.12394.

[13] L.E. de-Bashan, Y. Bashan, Immobilized microalgae for removing pollutants: Review of practical aspects, Bioresour. Technol. 101(6) (2010) 1611-1627.https://doi.org/10.1016/j.biortech.2009.09.043.

[14] M. Olaizola, Microalgal removal of $\mathrm{CO}_{2}$ from flue gases: Changes in medium $\mathrm{pH}$ and flue gas composition do not appear to affect the photochemical yield of microalgal cultures, Biotechnol. Bioproc. E. 8(6) (2003) 360367.https://doi.org/10.1007/BF02949280.

[15] I. Douskova, J. Doucha, K. Livansky, J. MacHat, P. Novak, D. Umysova, V. Zachleder, M. Vitova, Simultaneous flue gas bioremediation and reduction of microalgal biomass production costs, Appl. Microbiol. Biot. 82(1) (2009) 179-185.https://doi.org/10.1007/s00253-008-1811-9.

[16] B.D. Lee, W.A. Apel, M.R. Walton, Screening of cyanobacterial species for calcification, Biotechnol. Prog. 20(5) (2004) 1345-1351.https://doi.org/10.1021/bp0343561.

[17] N. Hanagata, T. Takeuchi, Y. Fukuju, D.J. Barnes, I. Karube, Tolerance of microalgae to high $\mathrm{CO}_{2}$ and high temperature, Phytochemistry 31(10) (1992) 3345-3348.https://doi.org/10.1016/0031-9422(92)83682-O.

[18] M.A. Borowitzka, Commercial production of microalgae: ponds, tanks, tubes and fermenters, J. Biotechnol. 70(1-3) (1999) 313-321.https://doi.org/10.1016/S0168-1656(99)00083-8.

[19] G. Naderi, M.O. Tade, H. Znad, Modified photobioreactor for biofixation of carbon dioxide by Chlorella vulgaris at different light intensities, Chem. Eng. Technol. 38(8) (2015) 13711379.https://doi.org/10.1002/ceat.201400790.

[20] K. Kumar, C.N. Dasgupta, B. Nayak, P. Lindblad, D. Das, Development of suitable photobioreactors for $\mathrm{CO}_{2}$ sequestration addressing global warming using green algae and cyanobacteria, Bioresour. Technol. 102(8) (2011) 4945-4953.https://doi.org/10.1016/j.biortech.2011.01.054.

[21] S.Y. Chiu, M.T. Tsai, C.Y. Kao, S.C. Ong, C.S. Lin, The air-lift photobioreactors with flow patterning for high-density cultures of microalgae and carbon dioxide removal, Eng. Life Sci. 9(3) (2009) 254260.https://doi.org/10.1002/elsc.200800113.

[22] W.Y. Cheah, P.L. Show, J.S. Chang, T.C. Ling, J.C. Juan, Biosequestration of atmospheric $\mathrm{CO}_{2}$ and flue gascontaining $\mathrm{CO}_{2}$ by microalgae, Bioresour. Technol. $184 \quad$ (2015) 201.https://doi.org/10.1016/j.biortech.2014.11.026. 
[23] R. Slade, A. Bauen, Micro-algae cultivation for biofuels: Cost, energy balance, environmental impacts and future prospects, Biomass Bioenerg. 53 (2013) 29-38.https://doi.org/10.1016/j.biombioe.2012.12.019.

[24] E. Eroglu, S.M. Smith, C.L. Raston, Application of various immobilization techniques for algal bioprocesses, in: N. Moheimani, M. McHenry, K. de Boer, P. Bahri (Eds.), Biomass and Biofuels from Microalgae. Biofuel and Biorefinery Technologies, Springer, Cham, 2015, pp. 19-44.

[25] N. Mallick, Biotechnological potential of immobilized algae for wastewater N, P and metal removal: A review, Biometals 15(4) (2002) 377-390.https://doi.org/10.1023/A:1020238520948.

[26] C. Tamponnet, F. Coslantino, J.-N. Barbotin, R. Calvayrac, Cytological and physiological behaviour of Euglena gracillis cells entrapped in a calcium alginate gel, Physiol. Plant. 63(3) (1985) 277283.https://doi.org/10.1111/j.1399-3054.1985.tb04265.x.

[27] C. Webb, G.A. Dervakos, Studies in Viable Cell Immobilization, R.G. Landes.1996.

[28] O.I. Bernal, C.B. Mooney, M.C. Flickinger, Specific photosynthetic rate enhancement by cyanobacteria coated onto paper enables engineering of highly reactive cellular biocomposite "leaves", Biotechnol. Bioeng. 111(10) (2014) 1993-2008.https://doi.org/10.1002/bit.25280.

[29] M.C. Flickinger, J.L. Schottel, D.R. Bond, A. Aksan, L.E. Scriven, Painting and printing living bacteria: Engineering nanoporous biocatalytic coatings to preserve microbial viability and intensify reactivity, Biotechnol. Prog. 23(1) (2007) 2-17.https://doi.org/10.1021/bp060347r.

[30] S.C.S. Martins, C.M. Martins, L.M.C.G. Fiuza, S.T. Santaella, Immobilization of microbial cells: A promising tool for treatment of toxic pollutants in industrial wastewater, Afr. J. Biotechnol. 12 (2013) 4412-4418. [31] F. Masmoudi, A. Bessadok, M. Dammak, M. Jaziri, E. Ammar, Biodegradable packaging materials conception based on starch and polylactic acid (PLA) reinforced with cellulose, Environ Sci Pollut Res 23(20) (2016) 20904-20914.https://doi.org/10.1007/s11356-016-7276-y.

[32] S. Acosta-Rubí, A.T. Campocosio, M.D.C. Montes-Horcasitas, L. Quintanar-Vera, F. Esparza-García, R. Rodríguez-Vázquez, Production of a halotolerant biofilm from green coffee beans immobilized on loofah fiber (Luffa cylindrica) and its effect on phenanthrene degradation in seawater, J. Environ. Sci. Heal. A 52(7) (2017) 632-640.https://doi.org/10.1080/10934529.2017.1294965.

[33] S. Mary Stella, U. Vijayalakshmi, Influence of chemically modified Luffa on the preparation of nanofiber and its biological evaluation for biomedical applications, J Biomed Mater Res A 107(3) (2019) 610620.https://doi.org/10.1002/jbm.a.36577.

[34] A. Zainab, S. Meraj, R. Liaquat, Study on natural organic materials as biofilm carriers for the optimization of anaerobic digestion, Waste Biomass Valori. (2019).https://doi.org/10.1007/s12649-019-00628-7.

[35] A. Saeed, M. Iqbal, Loofa (Luffa cylindrica) sponge: Review of development of the biomatrix as a tool for biotechnological applications, Biotechnol. Prog. 29(3) (2013) 573-600.https://doi.org/10.1002/btpr.1702.

[36] N. Akhtar, J. Iqbal, M. Iqbal, Removal and recovery of nickel(II) from aqueous solution by loofa spongeimmobilized biomass of Chlorella sorokiniana: Characterization studies, J. Hazard 108(1-2) (2004) 8594.https://doi.org/10.1016/j.jhazmat.2004.01.002.

[37] M. Iqbal, R.G.J. Edyvean, Loofa sponge immobilized fungal biosorbent: A robust system for cadmium and other dissolved metal removal from aqueous solution, Chemosphere 61(4) (2005) 510518.https://doi.org/10.1016/j.chemosphere.2005.02.060.

[38] N. Akhtar, A. Saeed, M. Iqbal, Chlorella sorokiniana immobilized on the biomatrix of vegetable sponge of Luffa cylindrica: A new system to remove cadmium from contaminated aqueous medium, Bioresour. Technol. 88(2) (2003) 163-165.https://doi.org/10.1016/S0960-8524(02)00289-4.

[39] D.V. Sriharsha, L. Kumar R, J. Savitha, Immobilized fungi on Luffa cylindrica: An effective biosorbent for the removal of lead, J. Taiwan Inst. Chem. Eng. 80 (2017) 589-595.https://doi.org/10.1016/j.jtice.2017.08.032.

[40] Y. Chen, N. Su, K. Zhang, S. Zhu, Z. Zhu, W. Qin, Y. Yang, Y. Shi, S. Fan, Z. Wang, Y. Guo, Effect of fiber surface treatment on structure, moisture absorption and mechanical properties of luffa sponge fiber bundles, Ind. Crop. Prod. 123 (2018) 341-352.https://doi.org/10.1016/j.indcrop.2018.06.079.

[41] R.W. Thimijan, R.D. Heins, Photometric, radiometric, and quantum light units of measurement: a review of procedures for interconversion., HortScience 18 (1983) 818-822.

[42] E. van der Grinten, M.G. Pikkemaat, E.J. van den Brandhof, G.J. Stroomberg, M.H. Kraak, Comparing the sensitivity of algal, cyanobacterial and bacterial bioassays to different groups of antibiotics, Chemosphere 80(1) (2010) 1-6.https://doi.org/10.1016/j.chemosphere.2010.04.011.

[43] J. Guo, K. Selby, A.B. Boxall, Comparing the sensitivity of chlorophytes, cyanobacteria, and diatoms to major-use antibiotics, Environ Toxicol Chem 35(10) (2016) 2587-2596.https://doi.org/10.1002/etc.3430.

[44] N.R. Moheimani, M.A. Borowitzka, A. Isdepsky, S.F. Sing, Standard Methods for Measuring Growth of Algae and Their Composition, in: M.A. Borowitzka, N.R. Moheimani (Eds.), Algae for Biofuels and Energy, Springer Netherlands, Dordrecht, 2013, pp. 265-284.

[45] M.J. Smith, Statistical Analysis Handbook, 2018 ed., The Winchelsea Press, Edinburgh, 2018. 
[46] P. Kosky, R. Balmer, W. Keat, G. Wise, Chapter 20 - Design Step 3. Evaluation of Alternatives and Selection of a Concept, in: P. Kosky, R. Balmer, W. Keat, G. Wise (Eds.), Exploring Engineering (Third Edition), Academic Press, Boston, 2013, pp. 383-396.

[47] J.C. Ogbonna, Y.C. Liu, Y.K. Liu, H. Tanaka, Loofa (Luffa cylindrica) sponge as a carrier for microbial cell immobilization, J. Ferment. Bioeng. 78(6) (1994) 437-442.https://doi.org/10.1016/0922-338X(94)90043-4.

[48] H. Hamano, S. Nakamura, J. Hayakawa, H. Miyashita, S. Harayama, Biofilm-based photobioreactor absorbing water and nutrients by capillary action, Bioresour. Technol. 223 (2017) 307311.https://doi.org/10.1016/j.biortech.2016.10.088.

[49] Y. Liu, Water transport and sorption in primary and secondary emulsion polymer films, Faculty of Engineering and Physical Sciences, University of Surrey, 2015.

[50] B. Craster, T.G.J. Jones, Permeation of a range of species through polymer layers under varying conditions of temperature and pressure: In Situ measurement methods, Polymers 11(6) (2019).1056. https://doi.org/10.3390/polym11061056.

[51] G.S. Araujo, L.J.B.L. Matos, L.R.B. Gonçalves, F.A.N. Fernandes, W.R.L. Farias, Bioprospecting for oil producing microalgal strains: Evaluation of oil and biomass production for ten microalgal strains, Bioresour. Technol. 102(8) (2011) 5248-5250.https://doi.org/10.1016/j.biortech.2011.01.089.

[52] Y.T. Huang, C.P. Su, High lipid content and productivity of microalgae cultivating under elevated carbon dioxide, Int. J. Environ. 11(3) (2014) 703-710.https://doi.org/10.1007/s13762-013-0251-y.

[53] T.G. Tornabene, G. Holzer, S.L. Peterson, Lipid profile of the halophilic alga, Dunaliella salina, Biochem. Biophys. Res. Commun. 96(3) (1980) 1349-1356.https://doi.org/10.1016/0006-291X(80)90099-6.

[54] M. Benedetti, V. Vecchi, S. Barera, L. Dall'Osto, Biomass from microalgae: the potential of domestication towards sustainable biofactories, Microb. Cell Fact. 17(1) (2018).173. https://doi.org/10.1186/s12934-018-1019$\underline{3}$.

[55] E.V. Kupriyanova, M.A. Sinetova, S.M. Cho, Y.I. Park, D.A. Los, N.A. Pronina, $\mathrm{CO}_{2}$-concentrating mechanism in cyanobacterial photosynthesis: organization, physiological role, and evolutionary origin, Photosynth Res 117(1-3) (2013) 133-46.https://doi.org/10.1007/s11120-013-9860-z.

[56] G.D. Price, M.R. Badger, F.J. Woodger, B.M. Long, Advances in understanding the cyanobacterial $\mathrm{CO}_{2^{-}}$ concentrating-mechanism (CCM): functional components, $\mathrm{Ci}$ transporters, diversity, genetic regulation and prospects for engineering into plants, J Exp Bot 59(7) (2008) 1441-61.https://doi.org/10.1093/jxb/erm112.

[57] Farajzadeh R., Zitha P. L. J., B. J., Enhanced mass transfer of $\mathrm{CO}_{2}$ into Water: Experiment and Modeling, Ind. Eng. Chem. Res. 48 (2009) 6423-6431.

[58] F. Garcia-Ochoa, E. Gomez, Bioreactor scale-up and oxygen transfer rate in microbial processes: an overview, Biotechnol Adv 27(2) (2009) 153-76.https://doi.org/10.1016/j.biotechadv.2008.10.006.

[59] M.C. Annesini, L. Marrelli, V. Piemonte, L. Turchetti, Mass transfer coefficient, Artificial Organ Engineering2017, pp. 23-31.

[60] S.Y. Choi, B. Park, I.G. Choi, S.J. Sim, S.M. Lee, Y. Um, H.M. Woo, Transcriptome landscape of Synechococcus elongatus PCC 7942 for nitrogen starvation responses using RNA-seq, Sci Rep 6 (2016) 30584.https://doi.org/10.1038/srep30584.

[61] B. Sajjadi, W.-Y. Chen, A.A.A. Raman, S. Ibrahim, Microalgae lipid and biomass for biofuel production: A comprehensive review on lipid enhancement strategies and their effects on fatty acid composition, Renewable and Sustainable Energy Reviews 97 (2018) 200-232.https://doi.org/10.1016/j.rser.2018.07.050.

[62] W. Klinthong, Y.H. Yang, C.H. Huang, C.S. Tan, A review: microalgae and their applications in $\mathrm{CO}_{2}$ capture and renewable energy, Aerosol Air Qual. Res. 15(2) (2015) 712-742.https://doi.org/10.4209/aaqr.2014.11.0299. [63] B.D.S. Vaz, J.A.V. Costa, M.G. Morais, Innovative nanofiber technology to improve carbon dioxide biofixation in microalgae cultivation, Bioresour. Technol. $273 \quad$ (2019) 592598.https://doi.org/10.1016/j.biortech.2018.11.054.

[64] M.C. Flickinger, O.I. Bernal, M.J. Schulte, J.J. Broglie, C.J. Duran, A. Wallace, C.B. Mooney, O.D. Velev, Biocoatings: challenges to expanding the functionality of waterborne latex coatings by incorporating concentrated living microorganisms, J. Coat. Technol. Res. 14(4) (2017) 791-808.https://doi.org/10.1007/s11998-017-9933-6. [65] Y. Chen, S. Krings, J.R. Booth, S.A.F. Bon, S. Hingley-Wilson, J.L. Keddie, Introducing Porosity in Colloidal Biocoatings to Increase Bacterial Viability, Biomacromolecules (2020).https://dx.doi.org/10.1021/acs.biomac.0c00649.

[66] R.A. Dickie, Paint adhesion, corrosion protection and interfacial chemistry, Prog. Org. Coat. 25 (1994) 3 22.https://doi.org/10.1016/0300-9440(94)00500-1.

[67] O.K. Lyngberg, V. Thiagarajan, D.J. Stemke, J.L. Schottel, L.E. Scriven, M.C. Flickinger, A patch coating method for preparing biocatalytic films of Escherichia coli, Biotechnol. Bioeng. 62(1) (1999) 4455.https://doi.org/10.1002/(SICI)1097-0290(19990105)62:1<44::AID-BIT6>3.0.CO;2-W.

[68] J. Gosse, B. Engel, J. C-H Hui, C. Harwood, M. C Flickinger, Progress toward a biomimetic leaf: 4,000 h of hydrogen production by coating-stabilized nongrowing photosynthetic Rhodopseudomonas palustris, Biotechnol. Prog. 26 (2010) 907-18.https://doi.org/10.1002/btpr.406. 
[69] M. Fidaleo, S. Charaniya, C. Solheid, U. Diel, M. Laudon, H. Ge, L.E. Scriven, M.C. Flickinger, A model system for increasing the intensity of whole-cell biocatalysis: investigation of the rate of oxidation of D-sorbitol to L-sorbose by thin bi-layer latex coatings of non-growing Gluconobacter oxydans, Biotechnol. Bioeng. 95(3) (2006) 446-58.https://doi.org/10.1002/bit.21051.

[70] J.S. MacCready, A.G. Vecchiarelli, In long bacterial cells, the Min system can act off-center, Mol. Microbiol. 109(3) (2018) 268-272.https://doi.org/10.1111/mmi.13995.

[71] F. Moronta-Barrios, J. Espinosa, A. Contreras, Negative control of cell size in the cyanobacterium Synechococcus elongatus PCC 7942 by the essential response regulator RpaB, FEBS Lett. 587(5) (2013) 504509.https://doi.org/10.1016/i.febslet.2013.01.023.

[72] S. Chaudry, P.A. Bahri, N.R. Moheimani, Potential of milking of microalgae grown on biofilm photobioreactor for renewable hydrocarbon production, Comput. Aided Chem. Eng., 2017, pp. 2497-2502.

[73] K. Brenner, L. You, F.H. Arnold, Engineering microbial consortia: a new frontier in synthetic biology, Trends Biotechnol. 26(9) (2008) 483-489.https://doi.org/10.1016/j.tibtech.2008.05.004.

[74] I. Cases, V. De Lorenzo, Genetically modified organisms for the environment: Stories of success and failure and what we have learned from them, Int. J. Microbiol. 8(3) (2005) 213222.https://doi.org/10.13039/501100000780.

[75] D. Schatz, E. Nagar, E. Sendersky, R. Parnasa, S. Zilberman, S. Carmeli, Y. Mastai, E. Shimoni, E. Klein, O. Yeger, Z. Reich, R. Schwarz, Self-suppression of biofilm formation in the cyanobacterium Synechococcus elongatus, Environ. Microbiol. 15(6) (2013) 1786-1794.https://doi.org/10.1111/1462-2920.12070.

[76] R. Parnasa, E. Nagar, E. Sendersky, Z. Reich, R. Simkovsky, S. Golden, R. Schwarz, Small secreted proteins enable biofilm development in the cyanobacterium Synechococcus elongatus, Sci. Rep. 6 (2016).32209. https://doi.org/10.1038/srep32209.

[77] E. Nagar, S. Zilberman, E. Sendersky, R. Simkovsky, E. Shimoni, D. Gershtein, M. Herzberg, S.S. Golden, R. Schwarz, Type 4 pili are dispensable for biofilm development in the cyanobacterium Synechococcus elongatus, Environ. Microbiol. 19(7) (2017) 2862-2872.https://doi.org/10.1111/1462-2920.13814.

[78] J.P. Park, M.J. Choi, S.H. Kim, S.H. Lee, H. Lee, Preparation of sticky Escherichia coli through surface display of an adhesive catecholamine moiety, Appl. Environ. Microbiol. 80(1) (2014) 4353.https://doi.org/10.1128/AEM.02223-13.

[79] J.A. Francisco, C. Stathopoulos, R.A.J. Warren, D.G. Kilburn, G. Georgiou, Specific adhesion and hydrolysis of cellulose by intact Escherichia coli expressing surface anchored cellulase or cellulose binding domains, Nat. Biotechnol. 11(4) (1993) 491-495.https://doi.org/10.1038/nbt0493-491.

[80] A. Melis, Solar energy conversion efficiencies in photosynthesis: Minimizing the chlorophyll antennae to maximize efficiency, Plant Sci. J. 177(4) (2009) 272-280.https://doi.org/10.1016/j.plantsci.2009.06.005.

[81] R. Xiao, Y. Zheng, Overview of microalgal extracellular polymeric substances (EPS) and their applications, Biotechnol Adv 34(7) (2016) 1225-1244.https://doi.org/10.1016/j.biotechadv.2016.08.004.

[82] H. Schmidt, M. Thom, L. King, S. Wieprecht, S.U. Gerbersdorf, The effect of seasonality upon the development of lotic biofilms and microbial biostabilisation, Freshwater Biology 61(6) (2016) 963978.https://doi.org/10.1111/fwb.12760.

[83] A.L. Morales-Garcia, R.G. Bailey, S. Jana, J.G. Burgess, The role of polymers in cross-kingdom bioadhesion, Philos Trans R Soc Lond B Biol Sci 374(1784) (2019) 20190192.https://doi.org/10.1098/rstb.2019.0192.

[84] N.S. Jakubovics, R.C. Shields, N. Rajarajan, J.G. Burgess, Life after death: the critical role of extracellular DNA in microbial biofilms, Lett Appl Microbiol 57(6) (2013) 467-75.https://doi.org/10.1111/lam.12134.

[85] N.A. Eckardt, G.W. Snyder, A.R. Portis, W.L. Ogren, Growth and photosynthesis under high and low irradiance of Arabidopsis thaliana antisense mutants with reduced ribulose-1, 5-bisphosphate carboxylase/oxygenase activase content, Plant Physiol. 113 (1997) 575-586.https://doi.org/10.1104/pp.113.2.575. [86] A.J. Cole, L. Mata, N.A. Paul, R. de Nys, Using $\mathrm{CO}_{2}$ to enhance carbon capture and biomass applications of freshwater macroalgae, GCB BioEnergy 6(6) (2014) 637-645.https://doi.org/10.1111/gcbb.12097.

[87] M. Adamczyk, J. Lasek, A. Skawinska, $\mathrm{CO}_{2}$ biofixation and growth kinetics of Chlorella vulgaris and Nannochloropsis gaditana, Appl. Biochem. Biotechnol. 179(7) (2016) 1248-61.https://doi.org/10.1007/s12010016-2062-3. 


\section{Loofah-based microalgae and cyanobacteria biocomposites for intensifying carbon}

\section{2 dioxide capture}

3

4 Pichaya In-na ${ }^{1, \#}$, Abbas A. Umar ${ }^{1, \#}$, Adam D. Wallace ${ }^{2}$, Michael C. Flickinger ${ }^{2}$, Gary S. Caldwell ${ }^{3}$ and 5 Jonathan G.M. Lee ${ }^{1, *}$

61 - School of Engineering, Newcastle University

72 - Department of Chemical and Biomolecular Engineering, North Carolina State University

83 - School of Natural and Environmental Sciences, Newcastle University

$9 \quad \#-$ These authors contributed equally to the study

$10 *$ - Corresponding author email: jonathan.lee@ncl.ac.uk,

11 Address: Merz Court, Claremont Road, Newcastle upon Tyne, UK, Postcode: NE1 7RU Telephone:

12 +44 (0) 191208 5201; Fax: +44 (0) 1912085292

13 ORCID IDs where available:

14 Pichaya In-na: 0000-0001-8735-5821

15 Abbas A. Umar: 0000-0002-8073-1721

16 Michael Flickinger: 0000-0002-2192-2501

17 Gary Caldwell: 0000-0001-5687-6894

18 Jonathan Lee: 0000-0002-2539-5235

19

20 
After $\mathrm{pH}$ adjustment, binders were formulated to have $5 \% \mathrm{w} / \mathrm{w}$ solids content using deionised water $\left(\mathrm{dH}_{2} \mathrm{O}\right)$. Approximately $1 \mathrm{ml}$ of each binder was mixed with $1 \mathrm{ml}$ of cell culture in 24 -multiwell plates. The cell/binder mixtures were cultured for seven days $\left(20^{\circ} \mathrm{C}, 16: 8\right.$ light:dark photoperiod at 2,500 lux $)$, after which the samples were diluted by a factor of 20 using $\mathrm{dH}_{2} \mathrm{O}$ and cell counts were conducted using an improved Neubauer Hawksley haemocytometer relative to suspension controls.

\section{Cell adhesion test}

A wet cell paste (WCP) was obtained for each test species by centrifuging 2 L of culture of known cell density. The centrifugation conditions varied depending on species; 5 mins at 966 RCF (Relative Centrifugal Force) for C. vulgaris, 10 mins at $1717 \mathrm{RCF}$ for $N$. oculata, 2 mins at $1717 \mathrm{RCF}$ for D. salina, and 30 mins at $1717 \mathrm{RCF}$ for the cyanobacteria. Loofah were autoclaved, then dried at $105{ }^{\circ} \mathrm{C}$ for $3 \mathrm{~h}$. After drying, they were stored overnight in a desiccator prior to immobilisation. For immobilisation, the loofah was cut into approximately $1 \times 1 \times 1 \mathrm{~cm}$ cubes and placed in 24-multiwell plates. The binder mixtures were formulated as per the contact toxicity test. Each binder was mixed with $2.5 \%$ and $5.0 \%$ v/v of WCP and vortexed for 10 to 20 seconds (Vortex Genie 2, Scientific Industries, Inc.) to form biocoatings. During mixing of the marine microalgae WCP, the artificial seawater reacted with the latex binders, subsequently the artificial seawater was premixed with the binders before mixing with the marine WCP. Approximately $2 \mathrm{ml}$ of biocoating was pipetted onto each loofah cube and dried at $30{ }^{\circ} \mathrm{C}$ for $24 \mathrm{~h}$. Once formed, each biocomposite was submerged in $2 \mathrm{ml}$ of growth medium and shaken in darkness at $80 \mathrm{rpm}$ for 1, 24, 48 and $72 \mathrm{~h}$. The growth medium was refreshed at each stated time interval and any cells released from the loofah surface were counted by haemocytometer and converted to a percentage of the cells loaded onto the loofah scaffold. A weighted decision matrix technique was used to identify the most suitable binders for each species based on toxicity and adhesion affinity to the loofah scaffold. Toxicity was given a higher weighting (ratio 3:2) as the maintenance of cell viability was deemed the more important characteristic. 


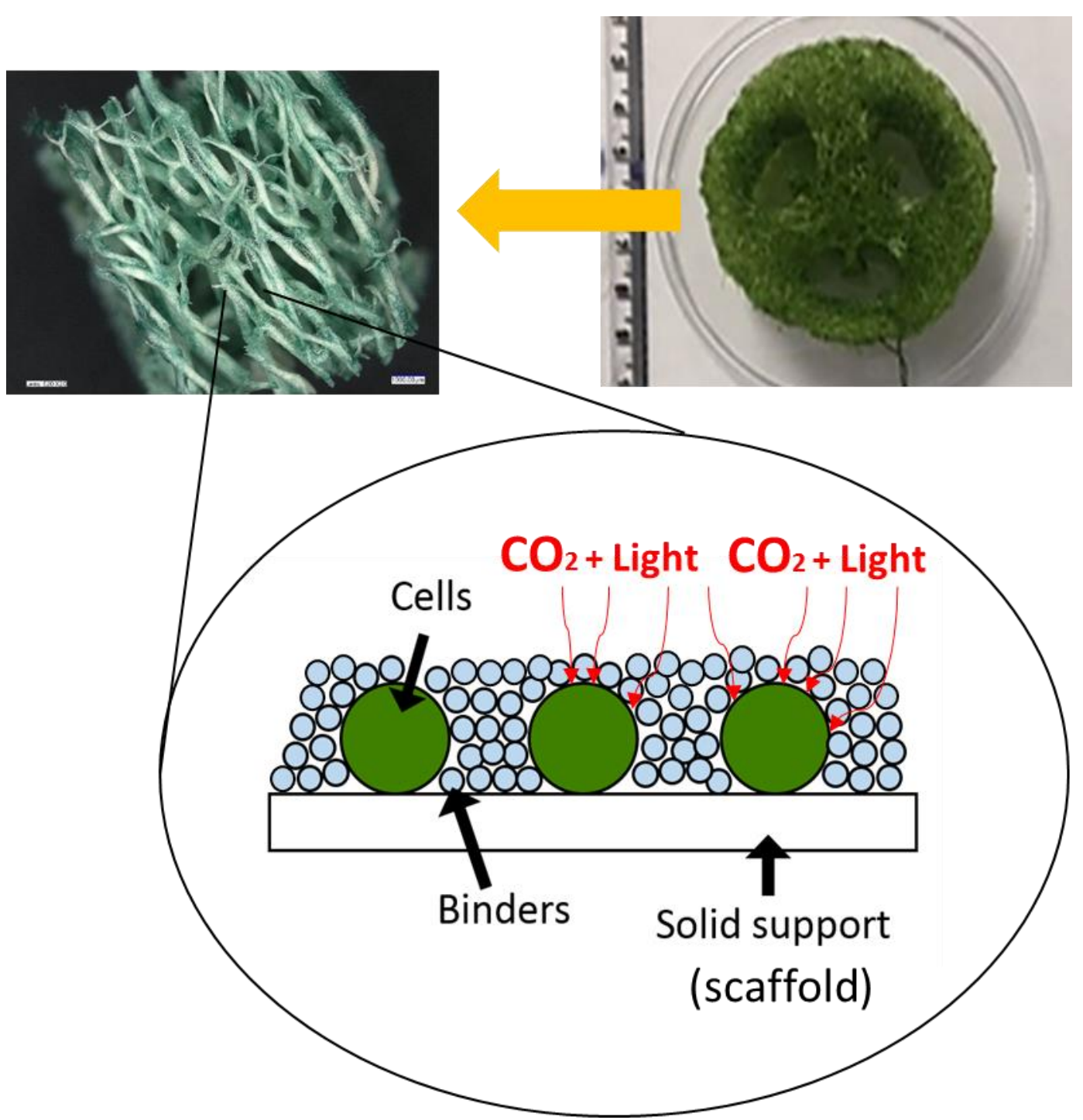

51 Fig. S1 Theoretical biofilm arrangement for loofah based biocomposites comprising cells and binder particles on a loofah scaffold. 

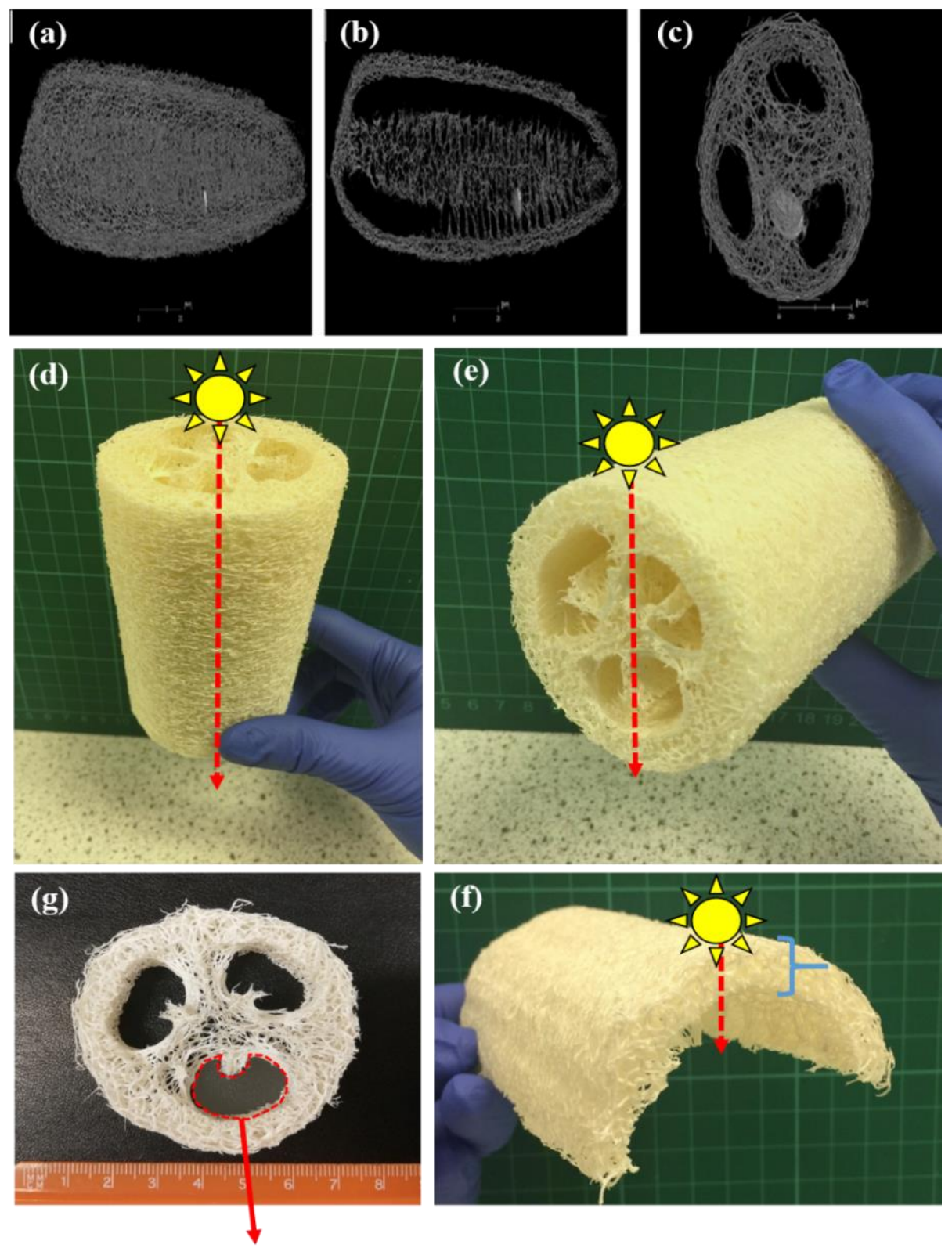

A void space at the centre of the loofah

Fig. S2 Illustrating the porosity and orientation of loofah for the light penetration test. CT scans of loofah (a-c):

(a) loofah external view in longitudinal orientation, (b) internal view in longitudinal orientation, (c) internal view in transverse section. (d-g) Orientation for light tests. The red line indicates the light path relative to the sun. The PAR sensor was encased in a lightproof tube to prevent peripheral light affecting the readings; (d) whole loofah in vertical orientation, (e) whole loofah in horizontal orientation, (f) half loofah (bracket denotes the loofah thickness), and (g) an example of void spaces within the loofah centre. 
Table S1 Name, coding and available compositional details of the synthetic petroleum based latex binders. N/A

$64=$ not available

\begin{tabular}{|c|c|c|c|c|c|}
\hline Binder name & $\begin{array}{l}\text { Binder } \\
\text { code }\end{array}$ & Main component & $\%$ Solid & $\begin{array}{l}\text { Additional } \\
\text { component }\end{array}$ & $\begin{array}{l}\text { Additional } \\
\text { component \% }\end{array}$ \\
\hline Rhoplex SF-3122 & $\mathrm{S} 1$ & Acrylic polymer & $60-61$ & Aqua ammonia & $0.2 \mathrm{Max}$ \\
\hline JP 912 & $\mathrm{~S} 2$ & Acrylic polymer & 51.1 & $\begin{array}{l}\text { Individual } \\
\text { residual } \\
\text { monomers }\end{array}$ & $<0.1$ \\
\hline Rhoplex SG -10M & S3 & $\begin{array}{l}\text { Butyl acrylate/Methyl } \\
\text { methacrylate }\end{array}$ & 51.3 & N/A & N/A \\
\hline PD-0413 & S4 & N/A & 80.4 & N/A & N/A \\
\hline PN-3415-W & S5 & N/A & 46.55 & N/A & N/A \\
\hline Genflo 8045 & S6 & $\begin{array}{l}\text { Modified styrene } \\
\text { butadiene }\end{array}$ & 57.1 & N/A & N/A \\
\hline Rhoplex SG-10 & S7 & Butyl/methyl methacrylate & $49-51$ & Aqua ammonia & $<=0.2$ \\
\hline HB $3691 \mathrm{M}$ & S8 & Polyester polyurethane & 48.4 & N/A & N/A \\
\hline Baycusan C-1000 & S9 & Polyester polyurethane & 40 & N/A & N/A \\
\hline Baycusan C-1004 & S10 & Polyester polyurethane & 40 & N/A & N/A \\
\hline $\begin{array}{l}\text { Baymedix CH-120 } \\
\text { polyurethane resin } \\
\text { dispersion }\end{array}$ & $\mathrm{S} 11$ & Polyurethane polymer & 34.7 & N/A & N/A \\
\hline $\begin{array}{l}\text { Nuplex Setaqua } \\
6776\end{array}$ & $\mathrm{~S} 12$ & Acrylic polymer & 42.8 & N/A & N/A \\
\hline Rhoplex SF-012 & S13 & Acrylic polymer & $43-44$ & Aqua ammonia & $<=0.1$ \\
\hline
\end{tabular}

65

66

67

68

69 
Table S2 Name, coding and available compositional details of the bio-based latex binders.

\begin{tabular}{|c|c|c|c|}
\hline Binder name & Binder code & Main components & $\%$ Solid \\
\hline AURO Clear lacquer glossy & B1 & $\begin{array}{l}\text { Water, colophony glycerol ester with } \\
\text { organic acids, mineral fillers, sunflower } \\
\text { oil, linseed oil, drying agents (cobalt-free), } \\
\text { caster stand oil, surfactants, amino soap, } \\
\text { silicic acid, cellulose, fatty acids }\end{array}$ & 29.10 \\
\hline $\begin{array}{l}\text { AURO Clear lacquer matt } \\
\text { silk }\end{array}$ & B2 & $\begin{array}{l}\text { Water, colophony glycerol ester with } \\
\text { organic acids, mineral fillers, sunflower } \\
\text { oil, linseed oil, drying agents (cobalt-free), } \\
\text { caster stand oil, surfactants, amino soap, } \\
\text { silicic acid, cellulose, fatty acids }\end{array}$ & 19.52 \\
\hline $\begin{array}{l}\text { AURO Woodstain } \\
\text { transparent }\end{array}$ & B3 & $\begin{array}{l}\text { Water, linseed oil, colophonium glycerine } \\
\text { ester with organic acids, mineral fillers, } \\
\text { surfactants, mineral pigments, silicic acids, } \\
\text { dryers (cobalt-free), castor stand oil, } \\
\text { sunflower seed oil, titanium dioxide, } \\
\text { ammonium soaps, cellulose, fatty acids }\end{array}$ & 13.68 \\
\hline AURO Color wash binder & B4 & $\begin{array}{l}\text { Water, ammonium soap, ammonium } \\
\text { carbonate, alcohol }\end{array}$ & 9.01 \\
\hline $\begin{array}{l}\text { AURO Ecological dispersion } \\
\text { wall paint }\end{array}$ & B5 & $\begin{array}{l}\text { Mineral fillers, water, Replebin, titanium } \\
\text { dioxide, cellulose, surfactants made of } \\
\text { rapeseed-, castor oil, ammonia and } \\
\text { thiazoles }\end{array}$ & 52.85 \\
\hline $\begin{array}{l}\text { AURO Ecological dispersion } \\
\text { wall paint }\end{array}$ & B6 & $\begin{array}{l}\text { Mineral fillers, water, Replebin, titanium } \\
\text { dioxide, cellulose, surfactants made of } \\
\text { rapeseed-, castor oil, ammonia and } \\
\text { thiazoles }\end{array}$ & 52.57 \\
\hline
\end{tabular}

79 

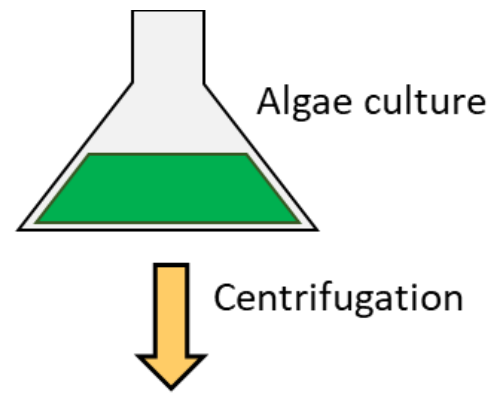

Latex binder Wet cell paste
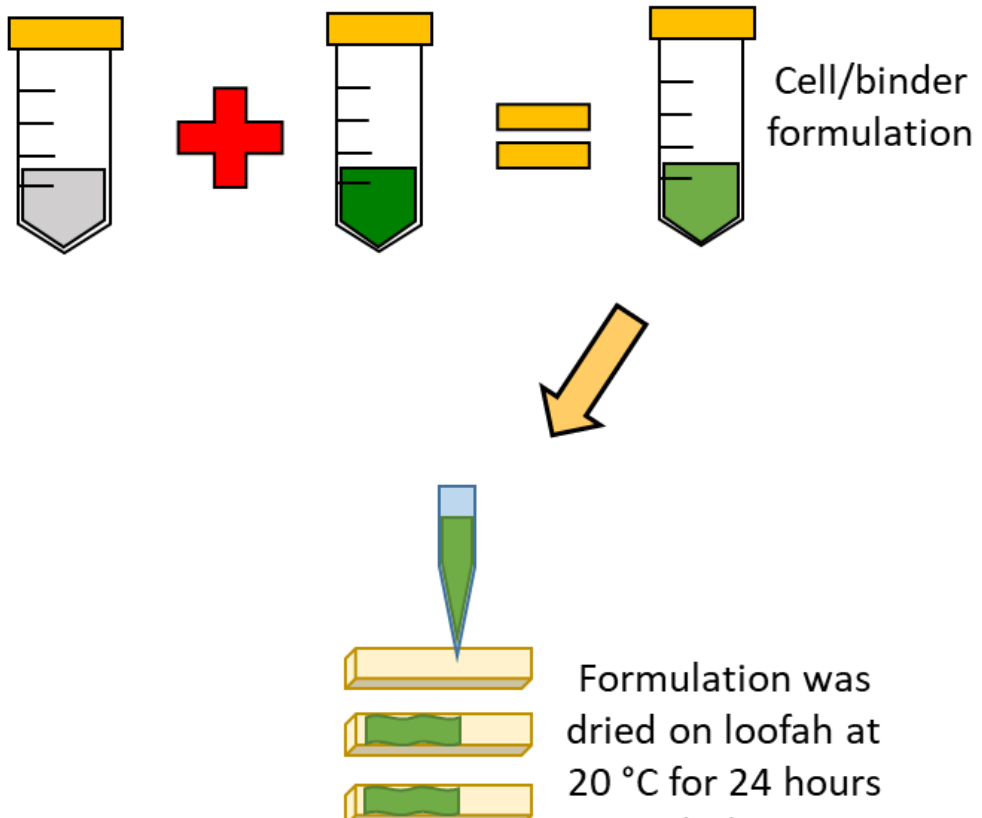

Formulation was

dried on loofah at

$20^{\circ} \mathrm{C}$ for 24 hours

in darkness

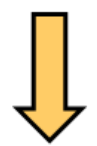

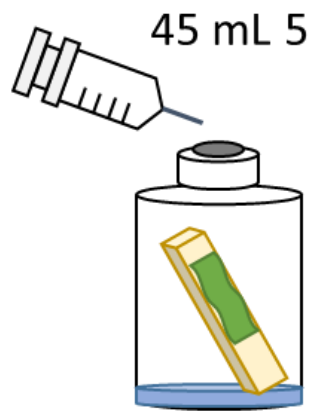

Samples

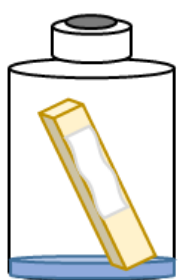

Abiotic controls Biotic controls

(no cell) (liquid suspension)

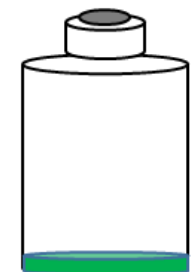
using latex binders for the semi-batch $\mathrm{CO}_{2}$ fixation test. 
In this section the simulation of diffusion in the control vials, filled with gas and a suspended microalgae or cyanobacteria culture, is described. The purpose of this work was to establish a rate constant for the removal of $\mathrm{CO}_{2}$ by the cells suspended in culture medium. The removal of $\mathrm{CO}_{2}$ by the cells is assumed to be a first order process.

This assumes that either mass dominates or that the reaction consuming $\mathrm{CO}_{2}$ is first order. The diffusion model in conjunction with experimental data were used to determine values for the volumetric transfer coefficient $\mathrm{K}$ ac. A second diffusion model was used to simulate vials with biocomposite and the values of the volumetric transfer coefficient were compared.

\subsection{Differential mass balances}

In the gas phase we assume diffusion is the only mass transfer mechanism. A mass balance and the application of Fick's first law leads to equation 1.1.

$101 \frac{\partial c^{G}}{\partial t}=D_{C O_{2}}^{G} \frac{\partial^{2} c^{G}}{\partial z^{2}}$

Assuming that:

1. there is no mixing in the liquid phase and that diffusion is the only mass transfer mechanism. Diffusion flux is in the axial direction; and

2. $\mathrm{CO}_{2}$ removal by the cells is represented by a reaction that is first order with respect to the concentration of $\mathrm{CO}_{2}$ in the liquid phase.

Using these assumptions a mass balance in the liquid phase leads to equation 1.2.

To solve these equations we have to spatially discretize them and solve the resulting set of ordinary differential equations. The vial is split into slices as shown in Fig. S4.

Since diffusion is the only transport mechanism for the $\mathrm{CO}_{2}$, the second order differentials in equations 1.1 and

1121.2 can be represented using second order central differences. Equations 1.1 and 1.2 are discretized to give equation 1.3 and 1.4 .

$114 \frac{\partial c_{i}^{G}}{\partial t}=D_{C O_{2}}^{G}\left(\frac{c_{i+1}^{G}-2 c_{i}^{G}+c_{i-1}^{G}}{\Delta z^{2}}\right)$

$115 \quad \frac{\partial c_{j}^{L}}{\partial t}=D_{C O_{2}}^{L}\left(\frac{c_{j+1}^{L}-2 c_{j}^{L}+c_{j-1}^{L}}{\Delta z^{2}}\right)-K a_{C} c_{i}^{L}$ 
117

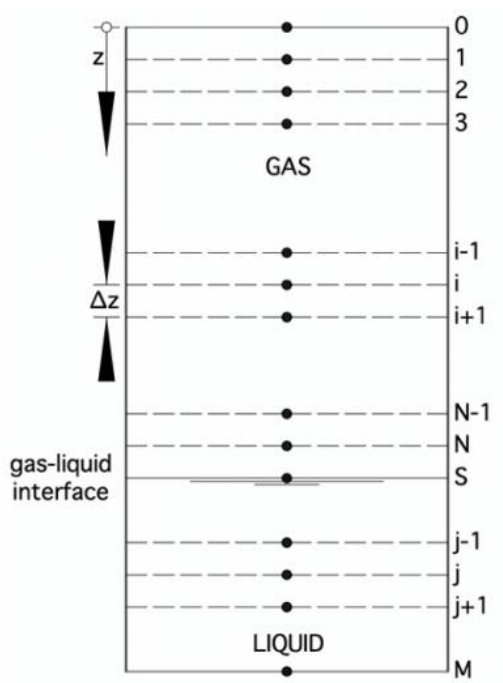

Fig. S4 The vial compartmentalised into a numerical grid.

\subsection{Boundary conditions}

There are three boundaries within the vial; the top of the vial, the gas-liquid interface, and the base of the vial.

\subsubsection{Top and bottom of the vial}

At the top and bottom of the vial, the wall prevents diffusion so the diffusion flux is zero. We used a forward difference at the top of the vial and a backwards difference at the bottom of the vial to represent the concentration gradient as shown in equations 1.5 and 1.6 .

$J_{0}^{G}=-\left.D_{C O_{2}}^{G} \frac{\partial c^{G}}{\partial z}\right|_{0}=0=-D_{C O_{2}}^{G}\left(\frac{-3 c_{0}^{G}+4 c_{1}^{G}-c_{2}^{G}}{2 \Delta z}\right)$

$J_{M}^{L}=-\left.D_{C O_{2}}^{L} \frac{\partial c^{L}}{\partial z}\right|_{M}=0=-D_{C O_{2}}^{L}\left(\frac{c_{M-2}^{L}-4 c_{M-1}^{L}+3 c_{M}^{L}}{2 \Delta z}\right)$

Equations 1.5 and 1.6 were solved for the gas concentration at the top of the vial $\left(c_{o}^{G}\right)$ and the liquid concentration at the base of the vial $\left(c_{M}^{L}\right)$, as given by equations 1.7 and 1.8 .

$c_{0}^{G}=\frac{4}{3} C_{1}^{G}-\frac{1}{3} C_{2}^{G} \quad(1.7)$

$c_{M}^{L}=\frac{4}{3} c_{M-1}^{L}-\frac{1}{3} c_{M-2}^{L}$

\subsubsection{Interface between gas and liquid}

At the interface between the gas and the liquid (surface S in Fig. S4) we assume that equilibrium exists between the phases. In this case the equilibrium is given by Dalton's law and Henry's law, as given by equation 1.7.

$y_{S} P=c_{S}^{G} R T=H c_{S}^{L}$ 

liquid phase (eqn. 1.9) are written in terms of the flux of $\mathrm{CO}_{2}$ instead of the concentration gradient.

$138 \quad \frac{\partial c_{N}^{G}}{\partial t}=\frac{J_{N}^{G}-J_{i}}{\Delta z_{G}}$

$139 \quad \frac{\partial c_{1}^{L}}{\partial t}=\frac{J_{i}-J_{1}^{L}}{\Delta z_{L}}$

140 The diffusion fluxes in the gas $\left(J_{N}^{G}\right)$ and liquid $\left(J_{1}^{L}\right)$ phases are estimated using Fick's law with second order 141 differences, as given by equations 1.10 and 1.11 .

$142 \quad J_{N}^{G}=-\left.D_{C O_{2}}^{G} \frac{\partial c^{G}}{\partial z}\right|_{N}=-D_{C O_{2}}^{G}\left(\frac{c_{N-2}^{G}-4 c_{N-1}^{G}+3 c_{N}^{G}}{2 \Delta z_{G}}\right)$

$J_{1}^{L}=-\left.D_{C O_{2}}^{L} \frac{\partial c^{L}}{\partial z}\right|_{1}=-D_{C O_{2}}^{L}\left(\frac{-3 c_{1}^{L}+4 c_{2}^{L}-c_{3}^{L}}{2 \Delta z_{L}}\right)$

144 The flux crossing the interface is calculated by applying two film theory around the interface so that the concentrations at point $\mathrm{N}$ in the gas phase and point 1 in the liquid phase can be used instead of interfacial concentrations. The flux is given by equation 1.12 .

$147 \quad J_{i}=K_{o v}\left(\frac{c_{N}^{G} R T}{H}-c_{1}^{L}\right)$

148 The overall mass transfer coefficient, $\mathrm{K}_{\mathrm{ov}}$, is given by equation 1.13.

149

$\frac{1}{K_{o v}}=\left(\frac{\Delta z_{L}}{D_{C O_{2}}^{L}}+\frac{\Delta z_{G}}{D_{C O_{2}}^{G}} \frac{R T}{H}\right)$

Substituting from equations $1.10,1.11$ and 1.12 into equations 1.8 and 1.9 leads to equations 1.14 and 1.15 which describe the way the $\mathrm{CO}_{2}$ concentration in the cells next to the interface change with time.

$\frac{\partial c_{N}^{G}}{\partial t}=\frac{1}{\Delta z_{G}}\left[D_{C O_{2}}^{G}\left(\frac{-c_{N-2}^{G}+4 c_{N-1}^{G}-3 c_{N}^{G}}{2 \Delta z_{G}}\right)-K_{o v}\left(\frac{c_{N}^{G} R T}{H}-c_{1}^{L}\right)\right]$

$\frac{\partial c_{1}^{L}}{\partial t}=\frac{1}{\Delta z_{L}}\left[K_{o v}\left(\frac{c_{N}^{G} R T}{H}-c_{1}^{L}\right)-D_{C O_{2}}^{L}\left(\frac{3 c_{1}^{L}-4 c_{2}^{L}+c_{3}^{L}}{2 \Delta z_{L}}\right)\right]-a_{C} k c_{1}^{L}$

\subsection{Making the equations dimensionless}

Defining the following characteristic variables

$$
\bar{t}=\frac{t}{\tau}
$$

where $\quad \tau=\frac{\Delta z_{0} z_{0}}{D_{0}}$

$\bar{z}=\frac{z}{z_{0}}$

$\Delta z_{0}=\frac{z_{0}}{N+1+M}$

157 The mass balances in the gas and liquid phases are transformed using dimensionless variables. The mass balances are given for the first cell in the gas layer, the cells in the middle of the gas layer, cell $\mathrm{N}$ in the gas layer, cell 1 in the liquid layer and cell M-1 in the liquid layer.

$$
\frac{\partial \bar{c}_{i}^{G}}{\partial \bar{t}}=\frac{2}{3} \frac{\Delta z_{0}}{z_{0}} \frac{D_{C O_{2}}^{G}}{D_{0}}\left(\frac{\bar{c}_{2}^{G}-\bar{c}_{1}^{G}}{\overline{\Delta z}_{G}^{2}}\right)
$$


$163 \quad \frac{\partial \bar{c}_{i}^{G}}{\partial \bar{t}}=\frac{\Delta z_{0}}{z_{0}} \frac{D_{C O_{2}}^{G}}{D_{0}}\left(\frac{\bar{c}_{i+1}^{G}-2 \bar{c}_{i}^{G}+\bar{c}_{i-1}^{G}}{\overline{\Delta z}_{G}^{2}}\right)$

$164 \quad$ Point $N$ in the gas layer

$165 \quad \frac{\partial \bar{c}_{N}^{G}}{\partial \bar{t}}=\frac{\Delta z_{0}}{z_{0}} \frac{1}{\overline{\Delta z_{G}}}\left[\left(\frac{D_{C O_{2}}^{G}}{D_{0}}\right)\left(\frac{-\bar{c}_{N-2}^{G}+4 \bar{c}_{N-1}^{G}-3 \bar{c}_{N}^{G}}{2 \overline{\Delta z_{G}}}\right)-\left(\frac{z_{0}}{D_{0}}\right) K_{o v}\left(\frac{\bar{c}_{N}^{G} R T}{H}-\bar{c}_{1}^{L}\right)\right]$

166 Point 1 in the liquid layer

167

$\frac{\partial \bar{c}_{1}^{L}}{\partial t}=\frac{\Delta z_{0}}{z_{0}} \frac{1}{\overline{\Delta z_{L}}}\left[\left(\frac{z_{0}}{D_{0}}\right) K_{o v}\left(\frac{\bar{c}_{N}^{G} R T}{H}-\bar{c}_{1}^{L}\right)-\left(\frac{D_{C O_{2}}^{L}}{D_{0}}\right)\left(\frac{3 \bar{c}_{1}^{L}-4 \bar{c}_{2}^{L}+\bar{c}_{3}^{L}}{2 \overline{\Delta \bar{z}_{L}}}\right)\right]-\left(\frac{z_{0} \Delta z_{0}}{D_{o}}\right) K a_{C} \bar{c}_{1}^{L}$

168

Points 2 to $M-2$ in the liquid layer

$169 \frac{\partial \bar{c}_{j}^{L}}{\partial \bar{t}}=\frac{\Delta z_{0}}{z_{0}} \frac{D_{C O_{2}}^{L}}{D_{0}}\left(\frac{\bar{c}_{j+1}^{L}-2 \bar{c}_{j}^{L}+\bar{c}_{j-1}^{L}}{\overline{\Delta z}_{L}^{2}}\right)-\left(\frac{z_{0} \Delta z_{0}}{D_{0}}\right) K a_{C} \bar{c}_{j}^{L}$

170

Point M-1 in the liquid layer

171

$\frac{\partial \bar{c}_{M-1}^{L}}{\partial \bar{t}}=\frac{2}{3} \frac{\Delta z_{0}}{z_{0}} \frac{D_{C O_{2}}^{L}}{D_{0}}\left(\frac{\bar{c}_{M-2}^{L}-\bar{c}_{M-1}^{L}}{\overline{\Delta z}_{L}^{2}}\right)-\left(\frac{z_{0} \Delta z_{0}}{D_{0}}\right) K a_{C} \bar{c}_{M-1}^{L}$

$172 \quad 1.4$ Solving the equations

173 Equations were set up and solved by numerical integration using Mathematica version 12. The following protocol

174 was adopted to ensure that the models represented the experimental situation.

175 Saturating the liquid with $\mathrm{CO}_{2}$

176 Run 1, saturate the liquid with $\mathrm{CO}_{2}$ at atmospheric concentrations of $\mathrm{CO}_{2}$. Runs 2-4, put initial gas concentration

177 up $5 \mathrm{~mol} \%$. Final gas and liquid compositions were the same between runs 3 and 4 .

178 Implementing the light dark cycles.

179 A piecewise function was used to simulate the light-dark cycles of the growth room. It was assumed that the gas 180 in the vial was changed at 15:00 and that the lights were switched off at 21:00 for eight hours. The schedule is 181 given in Table S3.

182 Table S3 Lighting schedule during the trial.

\begin{tabular}{cccc}
\hline Day & Time & Hours & Lights on/off \\
\hline 1 & $15: 00$ & 0 & on \\
1 & $21: 00$ & 6 & off \\
2 & $05: 00$ & 14 & on \\
2 & $21: 00$ & 30 & off \\
3 & $05: 00$ & 38 & on \\
\hline
\end{tabular}


184 These are based on assumptions: 1) one dimensional diffusion in the vial, 2) all vials contain the same number of 185 cells, and 3) all biocomposite samples contain the same number of cells as the suspended cultures in control vials

\subsection{Diffusion model for vials containing biocomposite}

\subsection{Mass balance equations and discretization}

In the gas surrounding the biocomposite sample a mass balance on an element with dimensions $\Delta \mathrm{x} \Delta \mathrm{y} \Delta \mathrm{z}(\Delta \mathrm{z}=$

1) leads to equation 2.1 .

$191 \frac{\partial c^{G}}{\partial t}=-\frac{\partial J_{x}}{\partial x}-\frac{\partial J_{y}}{\partial x}$

192 In the gas within the biocomposite sample, a mass balance on an element with dimensions $\Delta \mathrm{x} \Delta \mathrm{y} \Delta \mathrm{z}(\Delta \mathrm{z}=1)$,

193 including diffusion and $\mathrm{CO}_{2}$ consumption due to photosynthesis leads to equation 2.2.

$194 \quad \frac{\partial c^{G}}{\partial t}=-\frac{\partial J_{x}}{\partial x}-\frac{\partial J_{y}}{\partial x}-a_{B C} k C^{G}$

195

Using Fick's first law of diffusion to replace the diffusion fluxes in equations 2.1 and 2.2 leads to equations 2.3 and 2.4.

197

$$
\frac{\partial c^{G}}{\partial t}=D_{C O_{2}}^{G}\left(\frac{\partial_{2} c^{G}}{\partial x^{2}}+\frac{\partial_{2} c^{G}}{\partial y^{2}}\right)
$$

Equations 2.3 and 2.4 are solved by discretizing the spatial derivatives on the numerical grid shown in Fig. S5. the black lines represent the biocomposite sample, within these lines equation 2.4 is used for simulation. Outside the black lines equation 2.3 is used. The yellow lines represent symmetry boundaries and the green lines the wall of the vial. Using second order central second differences to replace the concentration gradients in equations 2.3 and 2.4 leads to equations 2.5 and 2.6. 


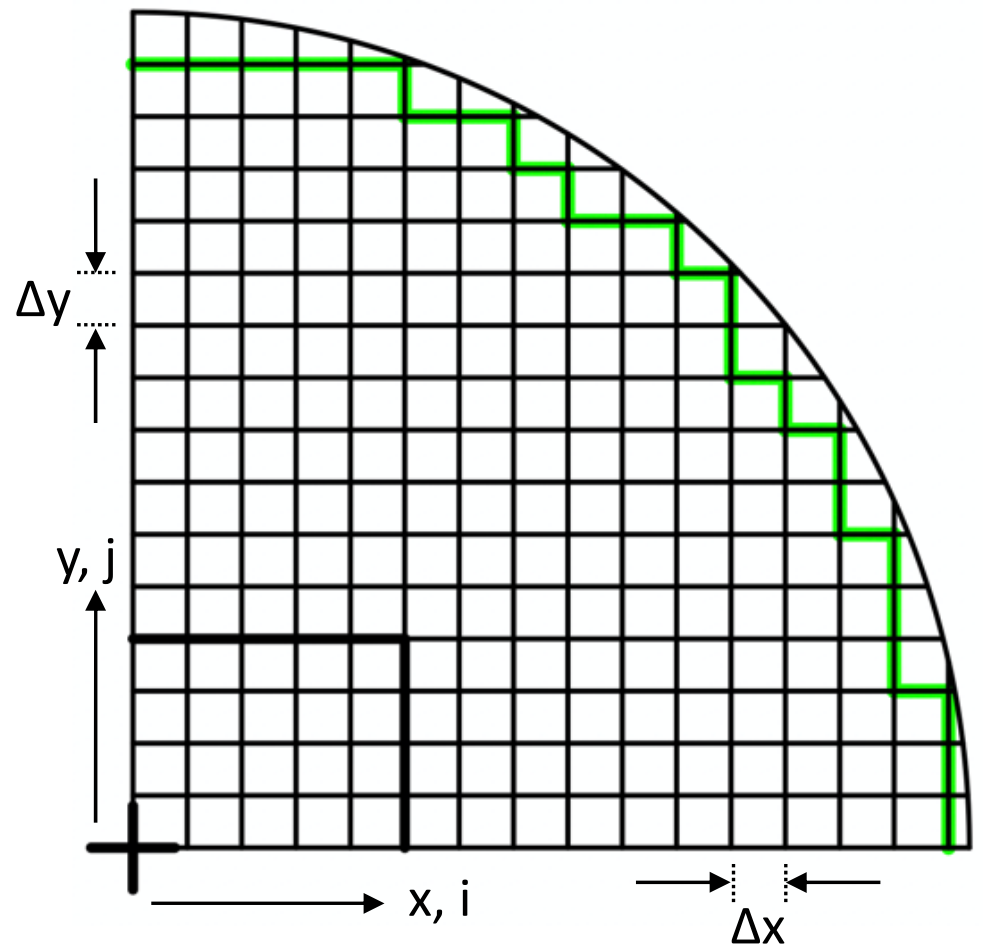

Fig. S5 The numerical grid.

Equation 2.3 or 2.4 is written for every point on the numerical grid within the green boundary. This leads to a set of ordinary differential equations that are solved over time to follow the evolution of $\mathrm{CO}_{2}$ concentration.

\subsection{Boundary conditions}

There are two boundary conditions that are applied at the boundaries of the numerical grid.

At the symmetry boundaries:

$$
\frac{\partial c^{G}}{\partial n}=0
$$

At the vial wall:

$$
J_{x}=J_{y}=0
$$

The remainder of this section with deal with the application of these boundary condition to the numerical grid shown in Fig. S5.

Symmetry boundaries

Along the x-axis symmetry boundary, diffusion in the y-direction is normal to the boundary, and on the $y$-axis symmetry boundary diffusion in the $\mathrm{x}$-direction is normal to the boundary. Therefore we can write that:

$$
\begin{aligned}
& \left.\frac{\partial c^{G}}{\partial y}\right|_{y=0}=\left.0 \quad \Rightarrow \quad \frac{\partial^{2} c^{G}}{\partial y^{2}}\right|_{y=0}=0 \\
& \left.\frac{\partial c^{G}}{\partial x}\right|_{x=0}=\left.0 \quad \Rightarrow \quad \frac{\partial^{2} c^{G}}{\partial x^{2}}\right|_{x=0}=0
\end{aligned}
$$


226 This simplifies the mass balance equations as follows. At the $\mathrm{x}$-axis symmetry boundary equations 2.7 and 2.8 are

227 used, depending on whether the point is inside or outside the biocomposite sample.

$228 \quad \frac{\partial c_{i, j}^{G}}{\partial t}=D_{C O_{2}}^{G}\left(\frac{c_{i+1, j}^{G}-2 c_{i, j}^{G}+c_{i-1, j}^{G}}{\Delta x^{2}}\right)$

$229 \quad \frac{\partial c_{i, j}^{G}}{\partial t}=D_{C O_{2}}^{G}\left(\frac{c_{i+1, j}^{G}-2 c_{i, j}^{G}+c_{i-1, j}^{G}}{\Delta x^{2}}\right)-a_{B C} k c_{i, j}^{G}$

230 At the y-axis symmetry boundary, equations 2.9 and 2.10 are used, depending on whether the point is inside or 231 outside the biocomposite sample.

$232 \quad \frac{\partial c_{i, j}^{G}}{\partial t}=D_{C O_{2}}^{G}\left(\frac{c_{i, j+1}^{G}-2 c_{i, j}^{G}+c_{i, j-1}^{G}}{\Delta y^{2}}\right)$

$\frac{\partial c_{i, j}^{G}}{\partial t}=D_{C O_{2}}^{G}\left(\frac{c_{i, j+1}^{G}-2 c_{i, j}^{G}+c_{i, j-1}^{G}}{\Delta y^{2}}\right)-a_{B C} k c_{i, j}^{G}$

234 At the centre of the vial and the biocomposite sample there are two symmetry boundaries. At this single point 235 there are no concentration gradients in the $\mathrm{x}$ or $\mathrm{y}$ direction and the mass balances simplifies to give equation (2.11).

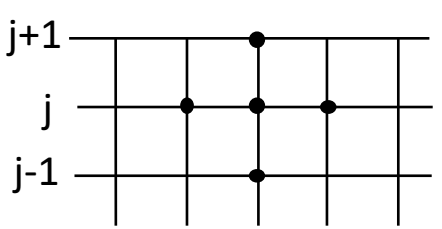

i-1 i i+1

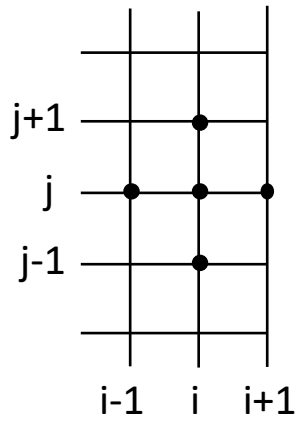

(b)

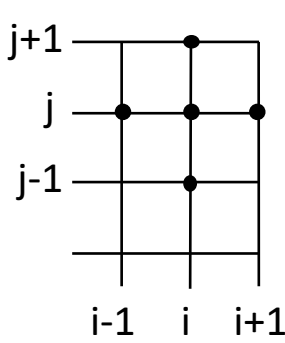

(c)

Fig. S6 Vial wall boundaries.

Vial boundaries

241 The different types of vial wall boundary cells in the numerical grid are shown in Fig. S6. These are horizontal wall Fig. S6(a), vertical wall Fig. S6(b) and a corner Fig. S6(c).

243 For the horizontal wall the flux normal to the wall is in the y-direction. The boundary condition at the wall is

$$
J_{i, j+1}=-\left.D_{C O_{2}}^{L} \frac{\partial c^{G}}{\partial y}\right|_{i, j+1}=0=-D_{C O_{2}}^{G}\left(\frac{c_{i, j-1}^{G}-4 c_{i, j}^{G}+3 c_{i, j+1}^{G}}{2 \Delta z}\right)
$$


solving equation 2.12 for $c_{i, j+1}^{G}$ gives $c_{i, j+1}^{G}=\frac{4}{3} c_{i, j}^{G}-\frac{1}{3} c_{i, j-1}^{G}$. Substituting this into equation 2.3 leads to equation 2.13 .

$\frac{\partial c_{i, j}^{G}}{\partial t}=D_{C O_{2}}^{G}\left(\frac{c_{i+1, j}^{G}-2 c_{i, j}^{G}+c_{i-1, j}^{G}}{\Delta x^{2}}+\frac{2}{3}\left[\frac{c_{c_{i, j-1}}^{G}-c_{i, j}^{G}}{\Delta y^{2}}\right]\right)$

249 For the vertical wall the flux normal to the wall is in the $\mathrm{x}$-direction. The boundary condition at the wall is

250

$J_{i+1, j}=-\left.D_{C O_{2}}^{L} \frac{\partial c^{G}}{\partial y}\right|_{i+1, j}=0=-D_{C O_{2}}^{G}\left(\frac{c_{i-1, j}^{G}-4 c_{i, j}^{G}+3 c_{i+1, j}^{G}}{2 \Delta z}\right)$

251 solving equation 2.14 for $c_{i+1, j}^{G}$ gives $c_{i+1, j}^{G}=\frac{4}{3} c_{i, j}^{G}-\frac{1}{3} c_{i-1, j}^{G}$. Substituting this into equation 2.3 leads to equation 2.15 .

253

$\frac{\partial c_{i, j}^{G}}{\partial t}=D_{C O_{2}}^{G}\left(\frac{2}{3}\left[\frac{c_{i-1, j}^{G}-c_{i, j}^{G}}{\Delta x^{2}}\right]+\frac{c_{i, j+1}^{G}-2 c_{i, j}^{G}+c_{i, j-1}^{G}}{\Delta y^{2}}\right)$

254 For a corner, the flux in the $y$-direction at point $(i, j+1)$ and the flux in the $x$-direction at point $(i+1, j)$ are both zero.

255 Solving equations 2.12 and 2.14 and substituting the results into equation 2.3 leads to equation 2.16.

$256 \quad \frac{\partial c_{i, j}^{G}}{\partial t}=\frac{2 D_{C O_{2}}^{G}}{3}\left(\frac{c_{i-1, j}^{G}-c_{i, j}^{G}}{\Delta x^{2}}+\frac{c_{i, j-1}^{G}-c_{i, j}^{G}}{\Delta y^{2}}\right)$

257 There are a further two types of wall point, those which lie on the symmetry boundaries. If a wall point lies on the $\mathrm{x}$-axis symmetry boundary then equation 2.17 is used and if it lies on the $\mathrm{y}$-axis then equation 2.18 is used.

$259 \quad \frac{\partial c_{i, j}^{G}}{\partial t}=\frac{2}{3} D_{C O_{2}}^{G}\left(\frac{c_{i-1, j}^{G}-c_{i, j}^{G}}{\Delta x^{2}}\right)$

$260 \quad \frac{\partial c_{i, j}^{G}}{\partial t}=\frac{2}{3} D_{C O_{2}}^{G}\left(\frac{c_{i, j-1}^{G}-c_{i, j}^{G}}{\Delta y^{2}}\right)$

261

\subsection{Making the equations dimensionless}

262

Defining the following characteristic variables

263

$\bar{c}=\frac{c}{c_{0}}$

$\bar{t}=\frac{t}{\tau}$

$\bar{x}=\frac{x}{r_{0}}$

$\bar{y}=\frac{y}{r_{0}}$

264

where

265

$\tau=\frac{\Delta r_{0} r_{0}}{D_{0}}$

$$
\Delta r_{0}=\min [\Delta x, \Delta y]
$$

266 According to whether biocomposite is present and applying the boundary conditions, equations 2.3, 2.4, 2.5, 2.6,

$2672.7,2.8,2.9,2.11,2.13,2.14,2.15$ and 2.16 are the mass balances that will be made dimensionless using these 268 characteristic variables. The dimensionless mass balances (equations 2.19-28) were solved to give the concentration in the vial as a function of time.

Gas only-type "G"

$271 \quad \frac{\partial \bar{c}_{i, j}^{G}}{\partial \bar{t}}=\frac{D_{C O_{2}}^{G}}{D_{0}} \frac{\Delta r_{0}}{r_{0}}\left(\frac{\bar{c}_{i+1, j}^{G}-2 \bar{c}_{i, j}^{G}+\bar{c}_{i-1, j}^{G}}{\overline{\Delta x^{2}}}+\frac{\bar{c}_{i, j+1}^{G}-2 \bar{c}_{i, j}^{G}+\bar{c}_{i, j-1}^{G}}{\overline{\Delta y^{2}}}\right)$ 
$273 \frac{\partial \bar{c}_{i, j}^{G}}{\partial \bar{t}}=\frac{D_{C O_{2}}^{G}}{D_{0}} \frac{\Delta r_{0}}{r_{0}}\left(\frac{\bar{c}_{i+1, j}^{G}-2 \bar{c}_{i, j}^{G}+\bar{c}_{i-1, j}^{G}}{\Delta x^{2}}+\frac{\bar{c}_{i, j+1}^{G}-2 \bar{c}_{i, j}^{G}+\bar{c}_{i, j-1}^{G}}{\Delta y^{2}}\right)-\left(\frac{\Delta r_{0} r_{0}}{D_{0}}\right) a_{B C} k \bar{c}_{i, j}^{G}$

274 Symmetry boundary ( $x$-axis) gas only-type "GSX"

$275 \quad \frac{\partial \bar{c}_{i, j}^{G}}{\partial \bar{t}}=\frac{D_{C O_{2}}^{G}}{D_{0}} \frac{\Delta r_{0}}{r_{0}}\left(\frac{\bar{c}_{i+1, j}^{G}-2 \bar{c}_{i, j}^{G}+\bar{c}_{i-1, j}^{G}}{\overline{\Delta x}^{2}}\right)$

276 Symmetry boundary (x-axis) biocomposite present-type "BSX"

$277 \quad \frac{\partial \bar{c}_{i, j}^{G}}{\partial \bar{t}}=\frac{D_{C O_{2}}^{G}}{D_{0}} \frac{\Delta r_{0}}{r_{0}}\left(\frac{\bar{c}_{i+1, j}^{G}-2 \bar{c}_{i, j}^{G}+\bar{c}_{i-1, j}^{G}}{\overline{\Delta x^{2}}}\right)-\left(\frac{\Delta r_{0} r_{0}}{D_{0}}\right) a_{B C} k \bar{c}_{i, j}^{G}$

278 Symmetry boundary (y-axis) gas only-type "GSY"

$279 \quad \frac{\partial \bar{c}_{i, j}^{G}}{\partial \bar{t}}=\frac{D_{C O_{2}}^{G}}{D_{0}} \frac{\Delta r_{0}}{r_{0}}\left(\frac{\bar{c}_{i, j+1}^{G}-2 \bar{c}_{i, j}^{G}+\bar{c}_{i, j-1}^{G}}{\overline{\Delta y}^{2}}\right)$

280 Symmetry boundary (y-axis) biocomposite present-type "BSY"

$281 \quad \frac{\partial \bar{c}_{i, j}^{G}}{\partial \bar{t}}=\frac{D_{C O_{2}}^{G}}{D_{0}} \frac{\Delta r_{0}}{r_{0}}\left(\frac{\bar{c}_{i, j+1}^{G}-2 \bar{c}_{i, j}^{G} \bar{c}_{i, j-1}^{G}}{\overline{\Delta y}}\right)-\left(\frac{\Delta r_{0} r_{0}}{D_{0}}\right) a_{B C} k \bar{c}_{i, j}^{G}$

282 Symmetry boundary centre of the vial with biocomposite present - type "CS"

$283 \quad \frac{\partial \bar{c}_{i, j}^{G}}{\partial \bar{t}}=-\left(\frac{\Delta r_{0} r_{0}}{D_{0}}\right) a_{B C} k \bar{c}_{i, j}^{G}$

284 Horizontal vial wall-type "WH"

$285 \quad \frac{\partial \bar{c}_{i, j}^{G}}{\partial \bar{t}}=\frac{D_{C O_{2}}^{G}}{D_{0}} \frac{\Delta r_{0}}{r_{0}}\left(\frac{\bar{c}_{i+1, j}^{G}-2 \bar{c}_{i, j}^{G}+\bar{c}_{i-1, j}^{G}}{\overline{\Delta x}^{2}}+\frac{2}{3}\left[\frac{\bar{c}_{c_{j-1}}^{G} \bar{c}_{i, j}^{G}}{\overline{\Delta y}^{2}}\right]\right)$

286 Vertical vial wall-type " $W V$ "

$287 \quad \frac{\partial \bar{c}_{i, j}^{G}}{\partial \bar{t}}=\frac{D_{C O_{2}}^{G}}{D_{0}} \frac{\Delta r_{0}}{r_{0}}\left(\frac{2}{3}\left[\frac{\bar{c}_{i-1, j}^{G}-\bar{c}_{i, j}^{G}}{\Delta x^{2}}\right]+\frac{\bar{c}_{i, j+1}^{G}-2 \bar{c}_{i, j}^{G}+\bar{c}_{i, j-1}^{G}}{\Delta y^{2}}\right)$

288 Corner vial wall - type "WC"

$289 \frac{\partial \bar{c}_{i, j}^{G}}{\partial \bar{t}}=\frac{2}{3} \frac{D_{C O_{2}}^{G}}{D_{0}} \frac{\Delta r_{0}}{r_{0}}\left(\frac{\bar{c}_{i-1, j}^{G}-\bar{c}_{i, j}^{G}}{\Delta x^{2}}+\frac{\bar{c}_{i, j-1}^{G}-\bar{c}_{i, j}^{G}}{\overline{\Delta y}^{2}}\right)$

290 Symmetry boundary ( $x$-axis) at the wall-type "WSX"

$291 \quad \frac{\partial \bar{c}_{i, j}^{G}}{\partial t}=\frac{2}{3} \frac{D_{C O_{2}}^{G}}{D_{0}} \frac{\Delta r_{0}}{r_{0}}\left(\frac{\bar{c}_{i-1, j}^{G}-\bar{c}_{i, j}^{G}}{\Delta x^{2}}\right)$

292 Symmetry boundary (y-axis) at the wall - type "WSY"

293

$$
\frac{\partial \bar{c}_{i, j}^{G}}{\partial t}=\frac{2}{3} \frac{D_{C O_{2}}^{G}}{D_{0}} \frac{\Delta r_{0}}{r_{0}}\left(\frac{\bar{c}_{i, j-1}^{G}-\bar{c}_{i, j}^{G}}{\overline{\Delta y}^{2}}\right)
$$

294 
298

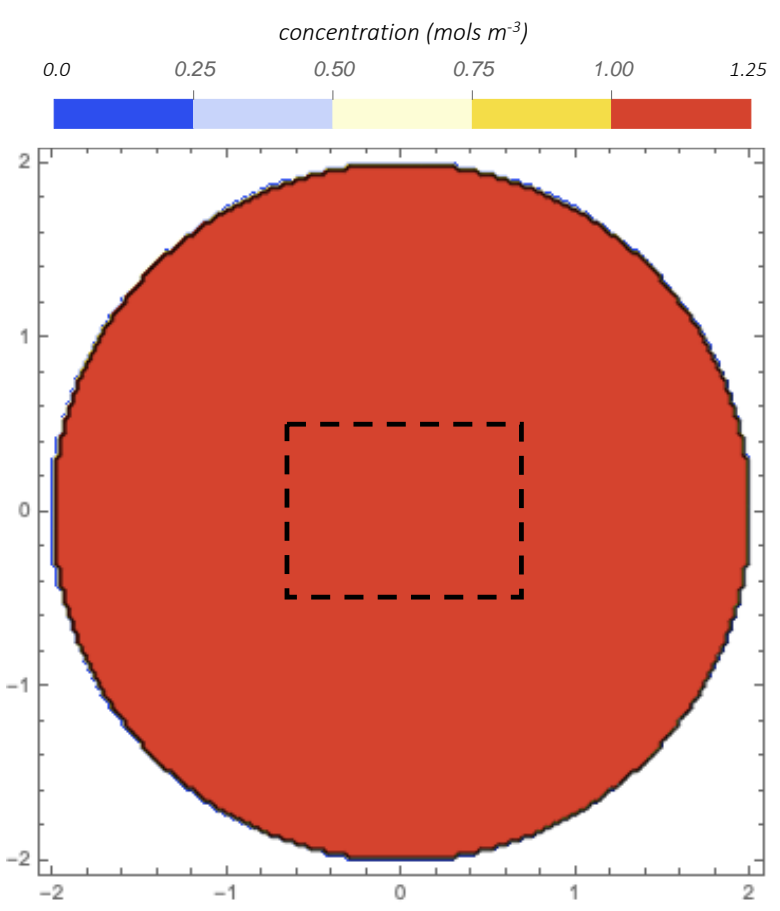

Fig. S7 Contour plot of the gas phase composition after 48 hours for CCAP 1479/1A biocomposite. Initial $\mathrm{CO}_{2}$ concentration $=2.05 \mathrm{mols} \mathrm{m}^{-3}\left(5 \mathrm{~mol} \% \mathrm{CO}_{2}\right)$, light:dark ratio 16:8. The transfer coefficient for the cells in the suspension controls in the vial is $5 \times 10^{-9} \mathrm{~m} \mathrm{~s}^{-1}$. The characteristic time for diffusion across the vial is much shorter than the characteristic time for transfer through the biocomposite. There are three options for the diffusion of $\mathrm{CO}_{2}$ through the latex coating.

1. The coating is a porous structure that $\mathrm{CO}_{2}$ gas diffuses through. The DVS experiments gave the value of diffusivity for this as approximately $10^{-8} \mathrm{~m}^{2} \mathrm{~s}^{-1}$.

2. The coating is a porous structure saturated with water. In this case the diffusivity will be approximately that for $\mathrm{CO}_{2}$ in water $\left(10^{-9} \mathrm{~m}^{2} \mathrm{~s}^{-1}\right)$.

3. The coating is a polymer film which the $\mathrm{CO}_{2}$ has to dissolve into the film and diffuse through it. The diffusivity for $\mathrm{CO}_{2}$ in polymer films is of the order of $10^{-13} \mathrm{~m}^{2} \mathrm{~s}^{-1}$.

The mass transfer coefficient for the biocomposite is given by the following equation.

$$
a_{C}\left(\frac{1}{K a_{C}}\right)_{\text {exp }}=\frac{1}{K_{\text {exp }}}=\frac{1}{k_{\text {cell }}}+\frac{1}{k_{\text {film }}}
$$

In this equation $\mathrm{k}_{\text {cell }}$ is the mass transfer coefficient for the cell in suspended culture. Using ranges of the surface area given in Table $\mathrm{S} 4$ we can calculate values for $\mathrm{k}_{\text {film. }}$.

$$
k_{f i l m}=\frac{D_{\text {film }}}{\Delta z_{\text {film }}}
$$


315 The change in the mass transfer coefficient indicates that the $\mathrm{CO}_{2}$ is having to diffuse through a solid polymer

316 film to reach the cells.

\section{$317 \quad$ Nomenclature}

$318 \mathrm{a}_{\mathrm{C}}-$ specific surface area of cell interface $\left(\mathrm{m}^{2} \mathrm{~m}^{-3}\right)$

$319 c^{G}-$ concentration of $\mathrm{CO}_{2}$ in the gas phase $\left(\mathrm{mols} \mathrm{m}^{-3}\right)$.

$320 c^{L}$ - concentration of $\mathrm{CO}_{2}$ in the liquid phase $\left(\mathrm{mols} \mathrm{m}^{-3}\right)$.

$321 \mathrm{c}_{0}-$ characteristic concentration $\left(\right.$ mols $\left.\mathrm{m}^{-3}\right)$.

$322 D_{\mathrm{CO}_{2}}^{G}-$ diffusivity of $\mathrm{CO}_{2}$ in the gas phase $\left(\mathrm{m}^{2} \mathrm{~s}^{-1}\right)$.

$323 D_{\mathrm{CO}_{2}}^{L}-$ diffusivity of $\mathrm{CO}_{2}$ in the liquid phase $\left(\mathrm{m}^{2} \mathrm{~s}^{-1}\right)$.

$324 D_{0}-$ characteristic diffusivity $\left(\mathrm{m}^{2} \mathrm{~s}^{-1}\right)$.

$325 \mathrm{~K}-$ transfer coefficient across the cell membrane incorporating the rate of $\mathrm{CO}_{2}$ consumption by the cell ( $\left.\mathrm{m} \mathrm{s}^{-1}\right)$.

$326 \mathrm{~K}_{\mathrm{ov}}$ - mass transfer coefficient for $\mathrm{CO}_{2}$ transport across the air-water interface $\left(\mathrm{m} \mathrm{s}^{-1}\right)$.

$327 \mathrm{~N}-$ number of cells in the gas layer.

$328 \mathrm{M}-$ number of cells in the liquid layer.

$329 \mathrm{t}$-time $(\mathrm{s})$.

$330 \mathrm{z}$ - axial distance in the vial $(\mathrm{m})$.

$331 \mathrm{z}_{0}-$ characteristic height $(\mathrm{m})$.

$332 \mathrm{t}$-characteristic time $\left(\Delta z_{0} z_{0} / D_{0}\right)(\mathrm{s})$.

333 Data

334 Diffusivity of $\mathrm{CO}_{2}$ in air $=1.6 \times 10^{-5} \mathrm{~m}^{2} \mathrm{~s}^{-1}$

335 Diffusivity of $\mathrm{CO}_{2}$ in water $=1.92 \times 10^{-9} \mathrm{~m}^{2} \mathrm{~s}^{-1}$

336 Henry's constant for $\mathrm{CO}_{2}$ in water at $25^{\circ} \mathrm{C}=2938 \mathrm{~m}^{3} \mathrm{~mol}^{-1} \mathrm{~Pa}$

337 Sample Vials

338 Microalgae:

$339 \mathrm{OD}=1.55 \mathrm{~cm}$, height $=9.8 \mathrm{~cm}$, wall thickness $=0.15 \mathrm{~cm}$,

340 Volume $=1 / 4 \pi(1.55-2 \times 0.15)^{2} \times 9.8=12.0 \mathrm{ml}$

341 Cyanobacteria:

$342 \mathrm{OD}=4.0 \mathrm{~cm}$, height $=7.3 \mathrm{~cm}$.

343 Height of straight section $=4.8 \mathrm{~cm}$, wall thickness $=0.13 \mathrm{~cm}$, base thickness $=0.28 \mathrm{~cm}$.

344 Curved section is $1.3 \mathrm{~cm}$ tall and diameter goes from $4.0 \mathrm{~cm}$ to $1.4 \mathrm{~cm}$. 
345 Top straight section has wall thickness of $2.2 \mathrm{~mm}$ and height of $8 \mathrm{~mm}$.

346 Volume of straight section at the bottom $=1 / 4 \pi(4.0-2 \times 0.13)^{2} \times(4.8-0.28)=49.7 \mathrm{ml}$

347 Volume of curved section $=\frac{2}{3} \times \pi \times 0.5 \times(4.0-0.26) \times 1.3^{2}=6.6 \mathrm{ml}$

348 Volume of straight section at the top $=1 / 4 \pi(1.4-2 \times 0.22)^{2} \times 0.8=0.6 \mathrm{ml}$

349 Total volume $=56.9 \mathrm{ml}$

350 Equivalent vial with an OD of $4.0 \mathrm{~cm}$, wall thickness $=0.13 \mathrm{~cm}$ and a height of $5.2 \mathrm{~cm}$.

351

352

353 

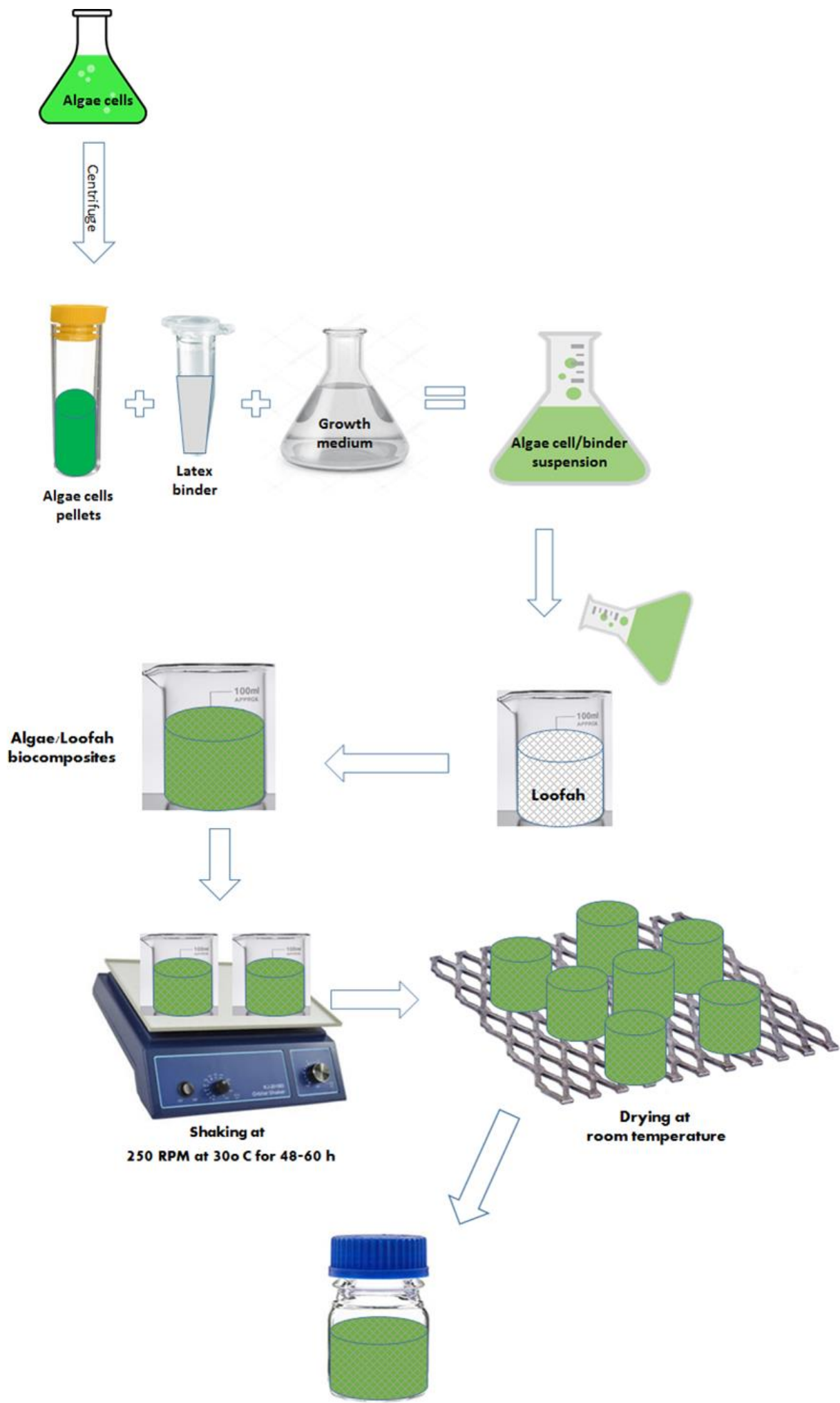

Biocomposite for $\mathrm{CO}_{2}$

$$
\text { reactivity }
$$

355 Fig. S8 A schematic sequence of the process to immobilise microalgae on loofah sponge using latex binders for the continuous $\mathrm{CO}_{2}$ test. 
363

364

365

366

367

368

369

370

371

372

373

374

375

376

377

378

379

380

381

382

383

384

385

386

387

Page $\mathbf{2 1}$ of $\mathbf{3 1}$ 
Table S4 Loss of photosynthetically active radiation (PAR) per unit depth (mm) for different loofah samples relative to ambient sunlight.

\begin{tabular}{lll}
\hline Sample & $\begin{array}{l}\text { Thickness }(\mathrm{mm}) \\
(\text { mean } \pm \text { Stdev })\end{array}$ & $\begin{array}{l}\text { PAR loss per unit depth } \\
(\% \text { loss } / \mathrm{mm} \text {; mean } \pm \text { Stdev })\end{array}$ \\
\hline Half loofah & $13.01 \pm 0.43$ & $7.11 \pm 0.02$ \\
Whole loofah (horizontal) & $54.63 \pm 0.72$ & $1.79 \pm 0.02$ \\
Whole loofah (vertical) & $100.8 \pm 0.27$ & $0.97 \pm 0.03$ \\
\hline
\end{tabular}

390 
391 Table S5 Photosynthetic conversion efficiency of the biocomposites as measured by bulk lipid content in the 392 continuous $\mathrm{CO}_{2}$ test.

\begin{tabular}{lll}
\hline Biocomposite & $\begin{array}{l}\text { \% lipid content per dry weight } \\
\text { biomass (mean } \pm \text { Stdev) }\end{array}$ & $\begin{array}{l}\text { \% photosynthetic conversion efficiency } \\
\text { (mean } \pm \text { Stdev) }\end{array}$ \\
\hline C. vulgaris $+\mathrm{S} 1$ & $69.38 \pm 1.27$ & $0.036 \pm 0.001$ \\
C. vulgaris $+\mathrm{S} 3$ & $51.96 \pm 11.82$ & $0.027 \pm 0.006$ \\
D. salina $+\mathrm{S} 1$ & $36.1 \pm 4.72$ & $0.019 \pm 0.002$ \\
D. salina $+\mathrm{S} 11$ & $66.22 \pm 6.02$ & $0.034 \pm 0.003$ \\
\hline
\end{tabular}

393 

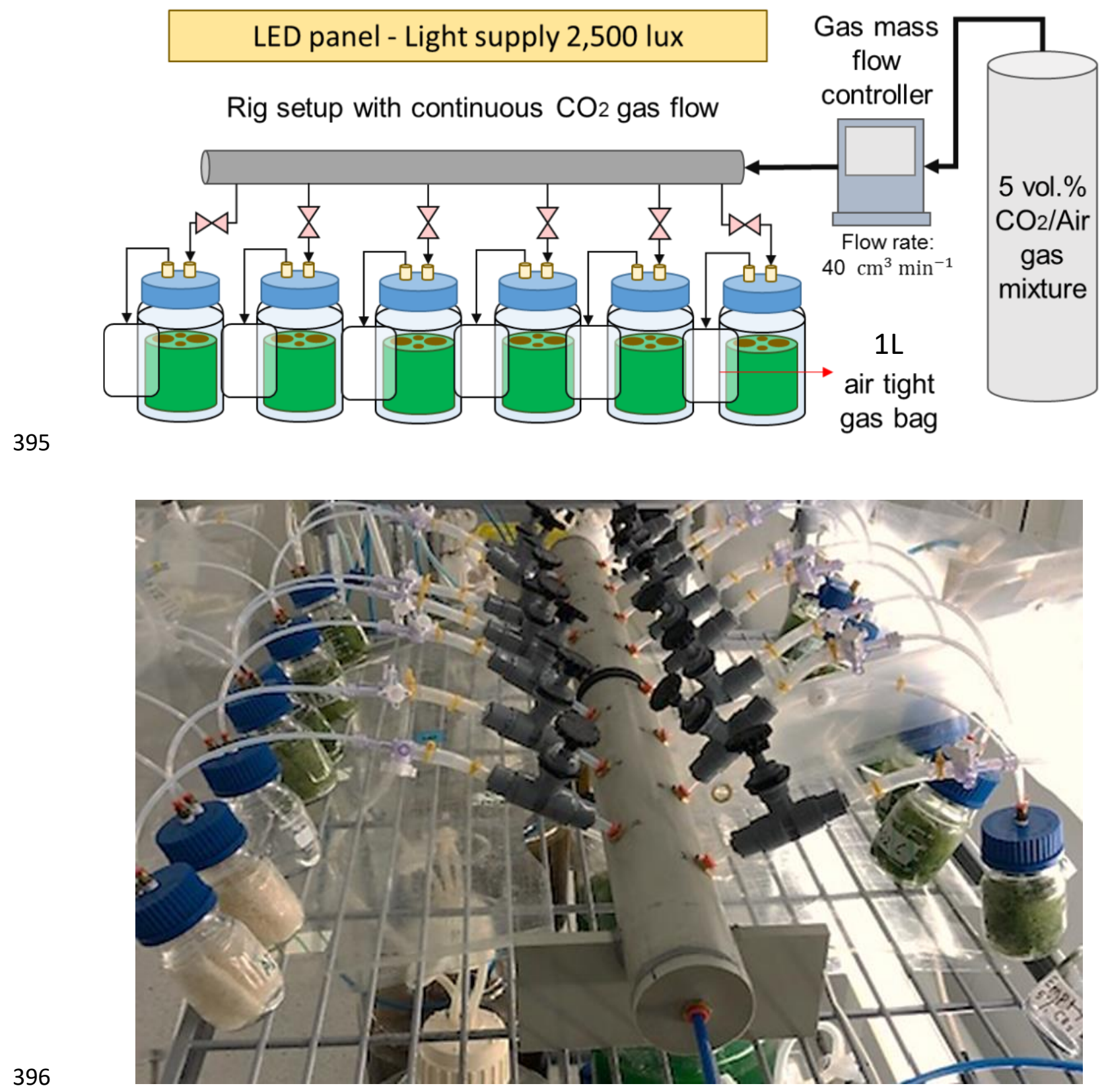

397

398 Fig. S9 Schematic (top) and photograph (bottom) of the microalgae biocomposite rig for the continuous $\mathrm{CO}_{2}$ 399 fixation test. 


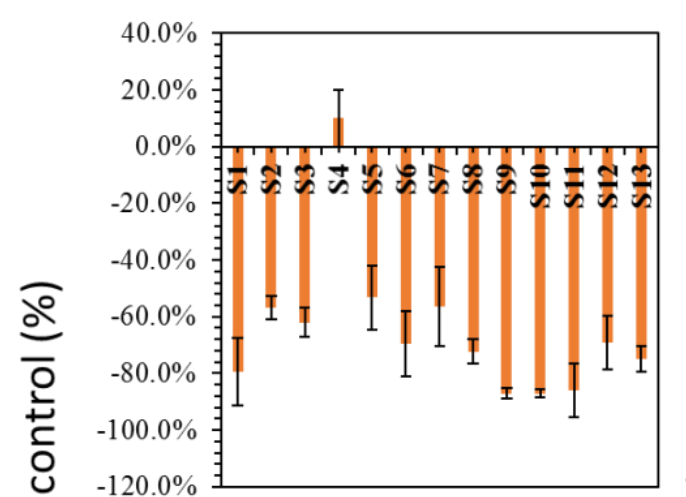

(a)

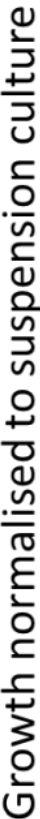

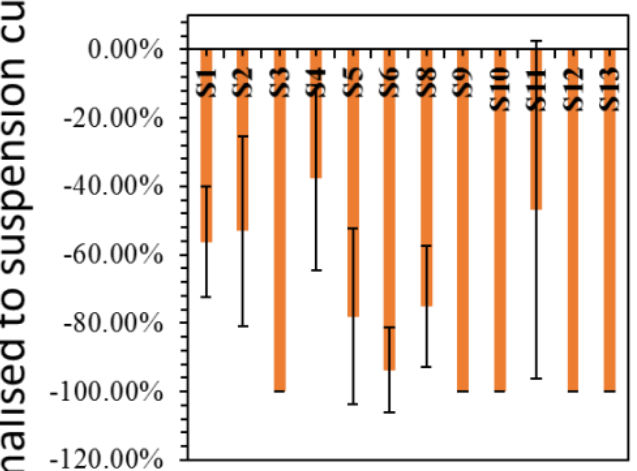

(c)

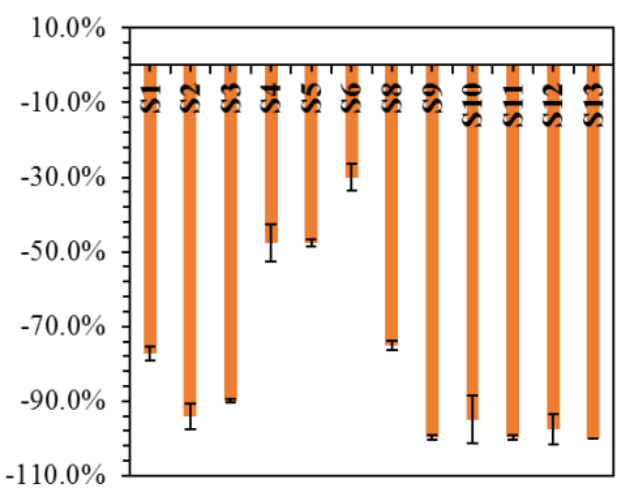

(b)

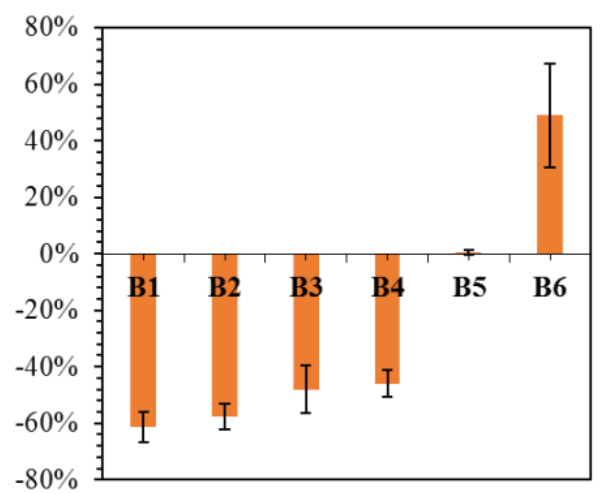

(d)

402

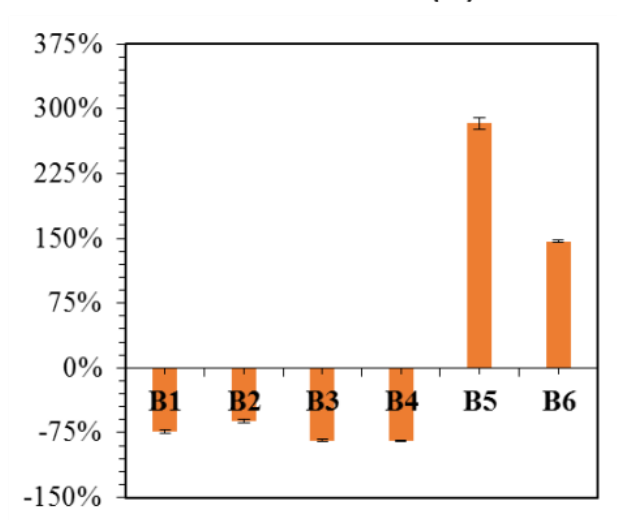

(e) Binders

403 Fig. S10 Toxicity testing using percentage growth normalised to suspension culture controls for (a) C. vulgaris,

404 (b) N. oculata, and (c) D. salina with synthetic binders, and (d) S. elongatus CCAP 14791/A and (e) PCC 7942 405 with bio-based binders. $C$. vulgaris: Kruskal-Wallis, $\mathrm{H}=46.09$, $\mathrm{df}=13, \mathrm{P}<0.001 ; N$. oculata: $\mathrm{H}=47.55$, $\mathrm{df}=$ 406 12, $\mathrm{P}<0.001 ;$ D. salina: $\mathrm{H}=37.41, \mathrm{df}=12, \mathrm{P}<0.001 ;$ S. elongatus $\mathrm{CCAP} 1479 / 1 \mathrm{~A}: \mathrm{H}=18.11, \mathrm{df}=6, \mathrm{P}=$ 407 0.006; Mann-Whitney, $\mathrm{U}=26\left(\mathrm{n}_{1,2}=0.3326\right), \mathrm{P}=0.0304$ and $\mathrm{PCC} 7942: \mathrm{H}=19.39$, $\mathrm{df}=6, \mathrm{P}=0.004$; MannWhitney, $\mathrm{U}=26\left(\mathrm{n}_{1,2}=1.4571\right), \mathrm{P}=0.03$. Refer to Tables $\mathrm{S} 1$ and $\mathrm{S} 2$ for binder details. 
$\begin{array}{lllllllllllllllllllllllll}A & B & C & D & E & F & \text { DAY } & A & B & C & D & E & F\end{array}$

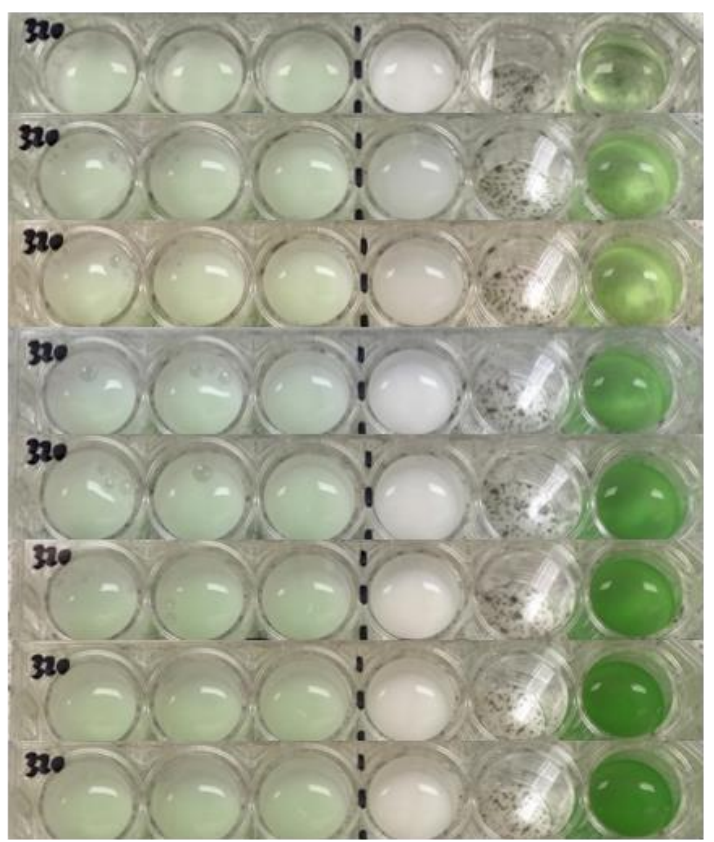

(a)

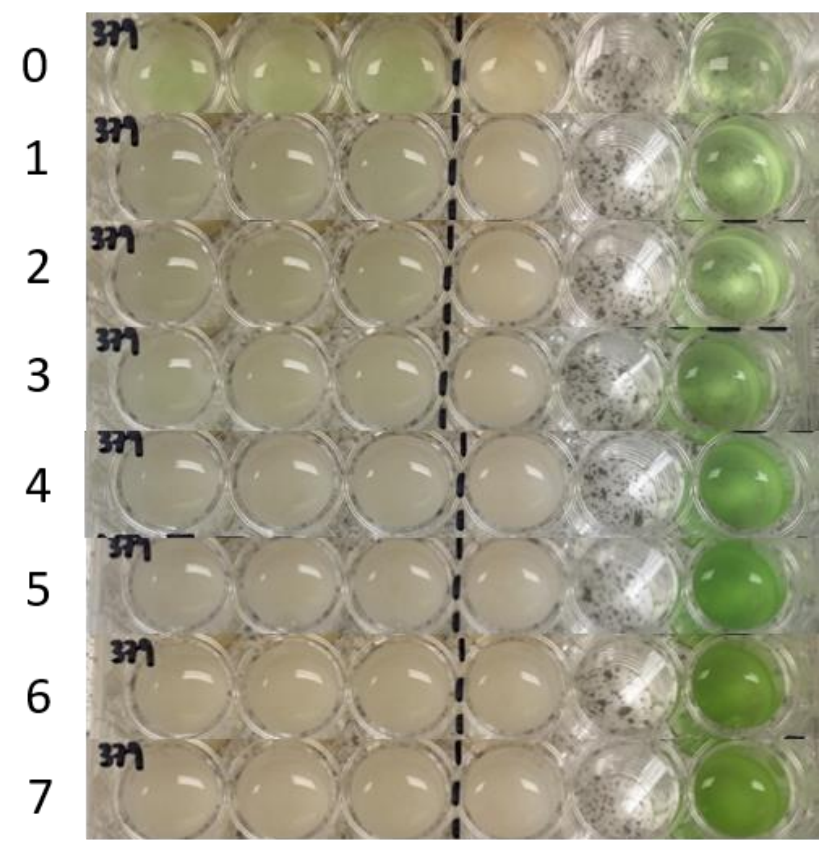

(b)

409

410 Fig. S11 A representative 7-day toxicity test using S. elongatus CCAP 1479/1 A with binders (a) B6 and (b) B4.

411 A-C = binder + growth medium + cells, D = binder + growth medium, E = growth medium, F = growth medium $412+$ cells. 

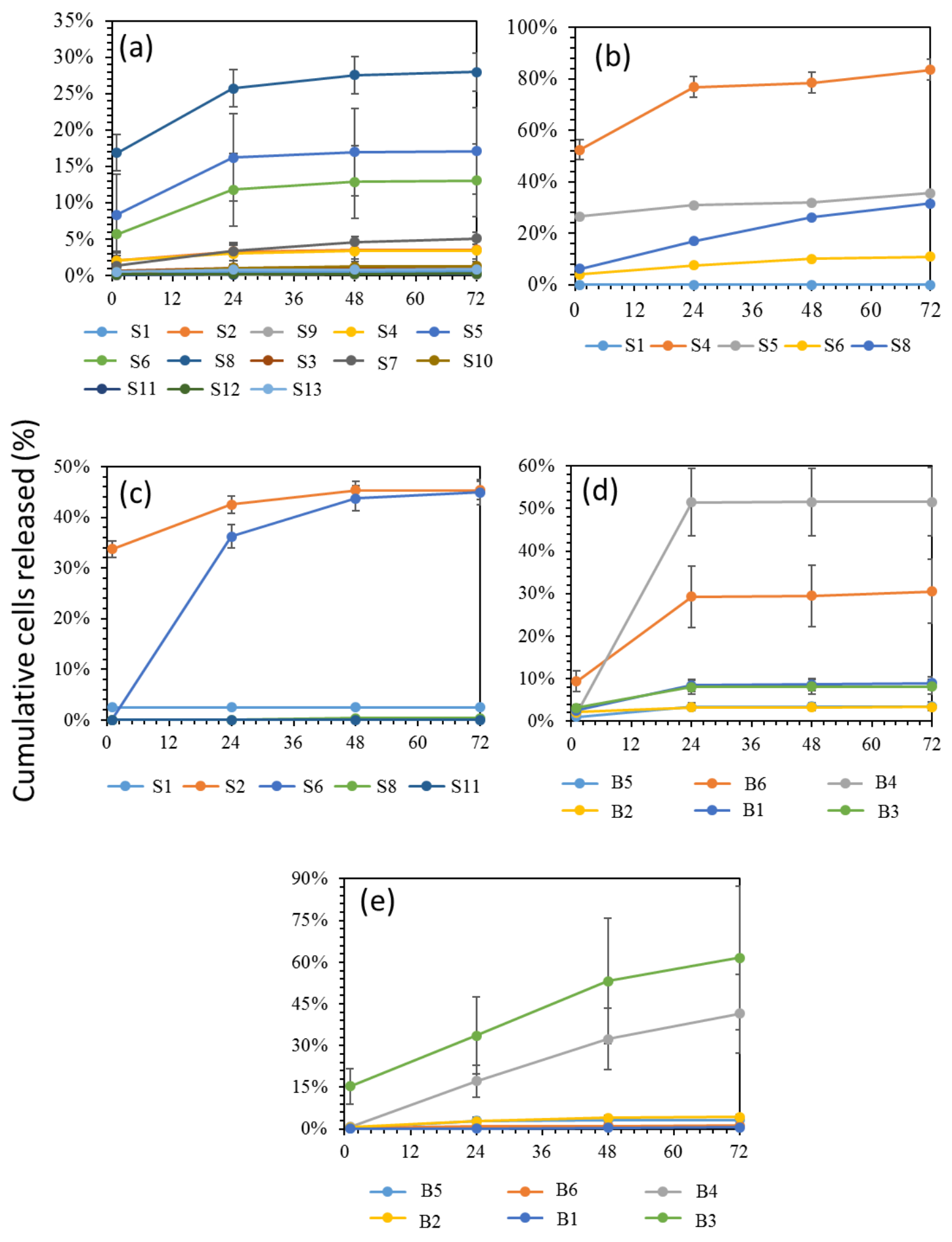

Time (h)

415 Fig. S12 Cumulative percentage of cells released from (a) C. vulgaris, (b) N. oculata, (c) D. salina, (d) $S$.

416 elongatus CCAP 1479/1A and (e) PCC 7942 biocomposites. Determined as the cumulative release of cells; $C$.

417 vulgaris: Kruskal-Wallis, $\mathrm{H}=49.03, \mathrm{df}=12, \mathrm{P}=\langle 0.001$, D. salina: $\mathrm{H}=16.57, \mathrm{df}=4, \mathrm{P}=0.002, N$. oculata: $\mathrm{H}$

$418=17.50, \mathrm{df}=4, \mathrm{P}=0.002$, S. elongatus $\mathrm{CCAP} 1479 / 1 \mathrm{~A}: \mathrm{H}=15.74, \mathrm{df}=5, \mathrm{P}=0.008$ and $\mathrm{PCC} 7942: \mathrm{H}=15.62$,

$419 \mathrm{df}=5, \mathrm{P}=0.008$. Refer to Tables $\mathrm{S} 1$ and $\mathrm{S} 2$ for binder details. 


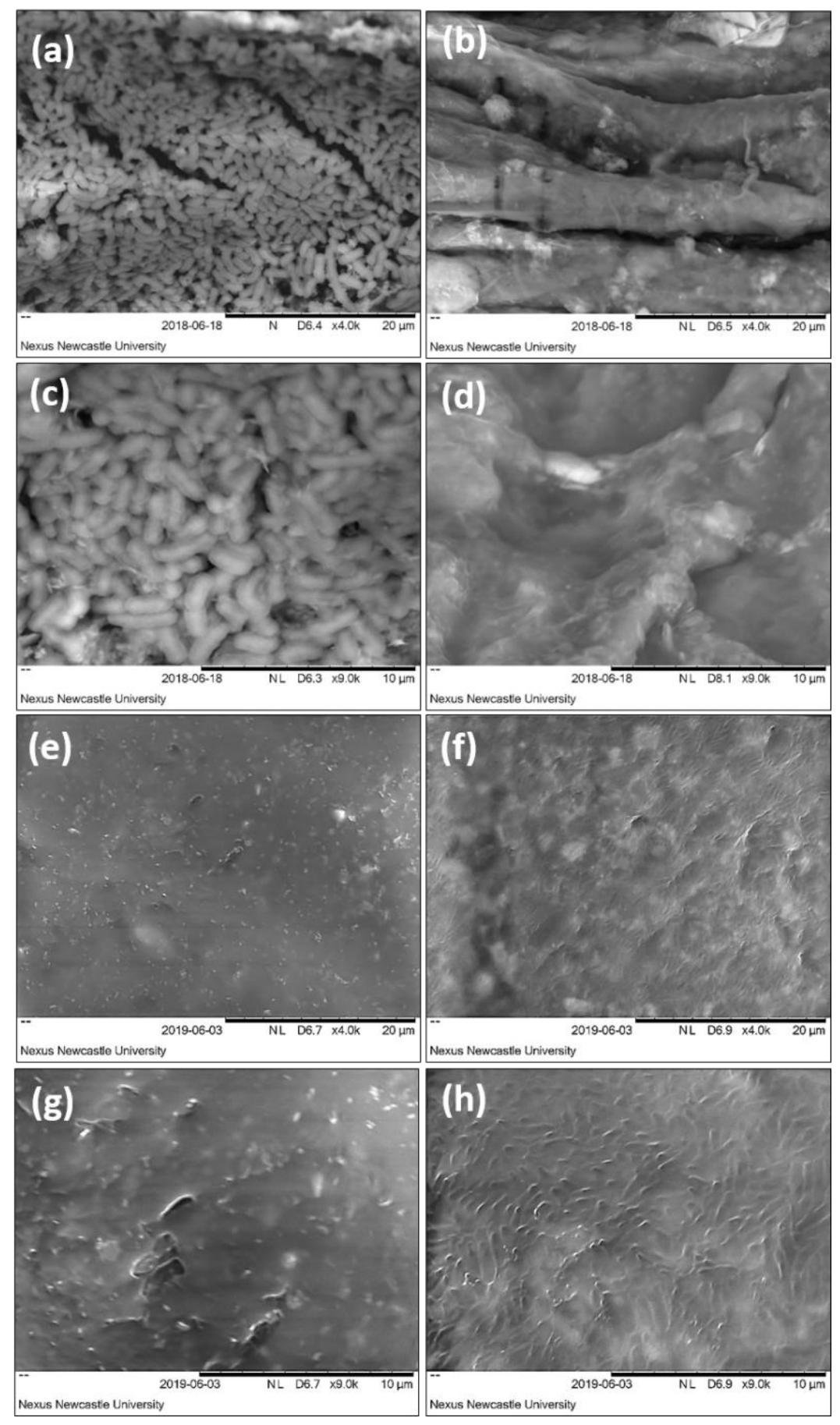

421 Fig. S13 SEM images of S. elongatus PCC 7942 biocomposites before and after adhesion testing. Binder B3

422 exhibiting poor cell retention (before $=\mathrm{a} \& \mathrm{c}$, after $=\mathrm{b} \& \mathrm{~d}$ ), binder B1 exhibiting good cell retention $(\mathrm{before}=\mathrm{e} \& \mathrm{~g}$,

423 after $=\mathrm{f} \& \mathrm{~h})$. Magnification: $4000 \times(\mathrm{a}, \mathrm{b}, \mathrm{e}, \mathrm{f})$ and $9000 \times(\mathrm{c}, \mathrm{d}, \mathrm{g}, \mathrm{h})$. 


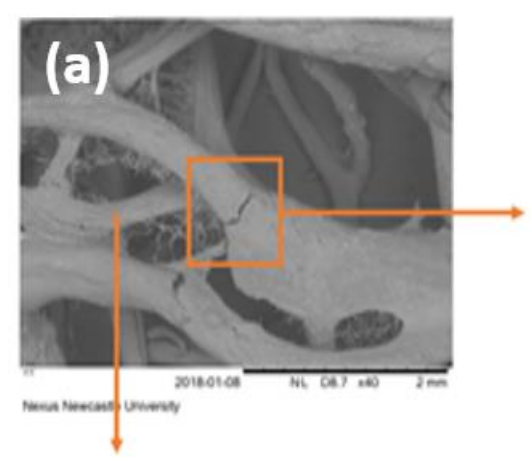

Loofah strand

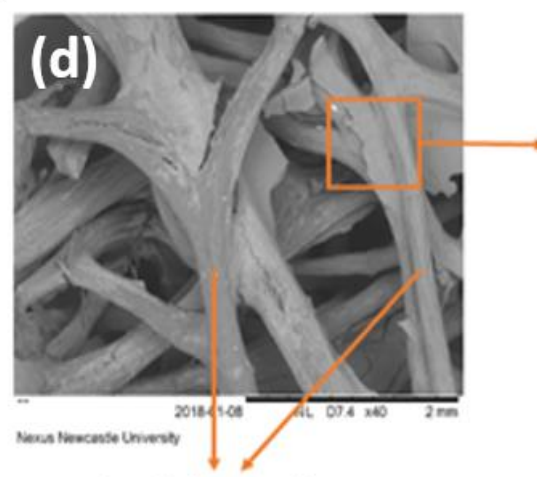

Loofah strand

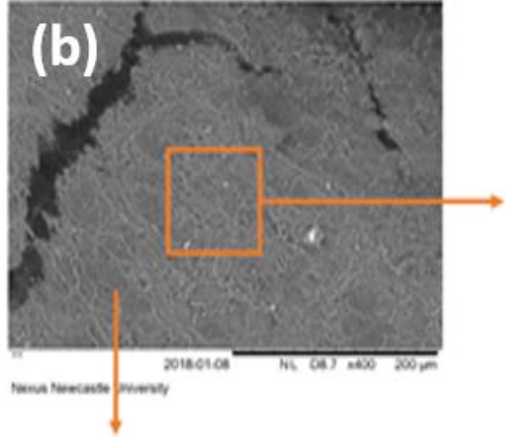

Latex binder with cells

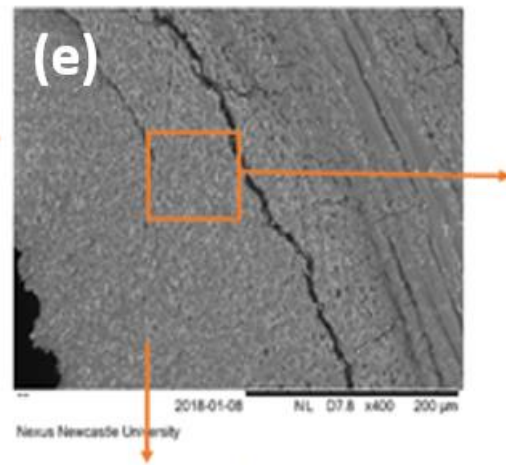

Latex binder with cells

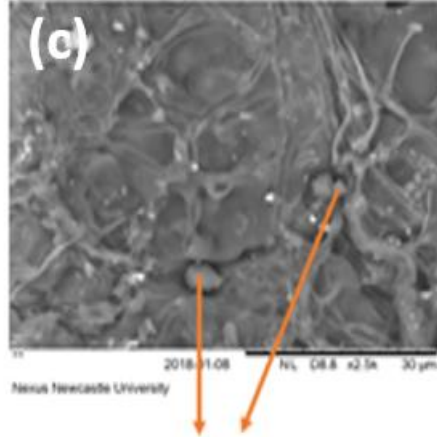

C. vulgaris cells

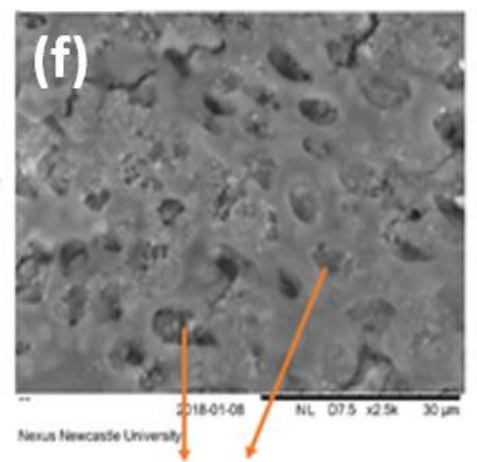

Spaces left where cells of $D$. salina were entrapped

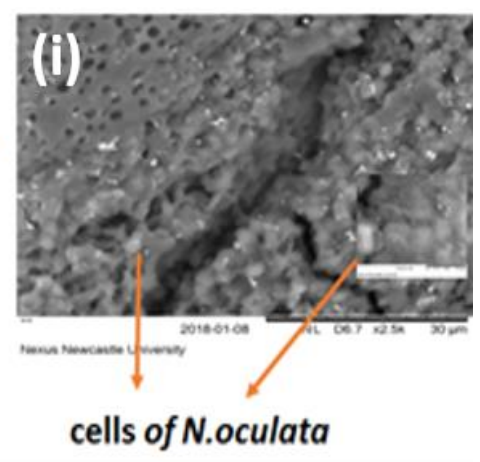

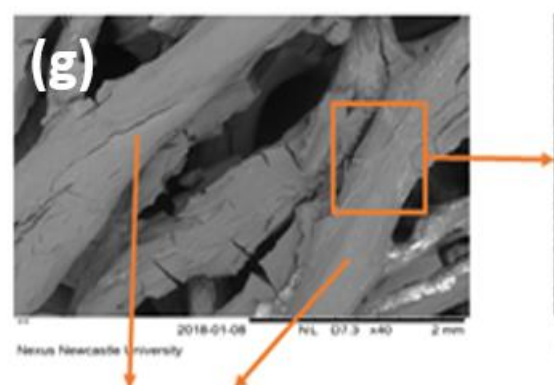

Loofah strand

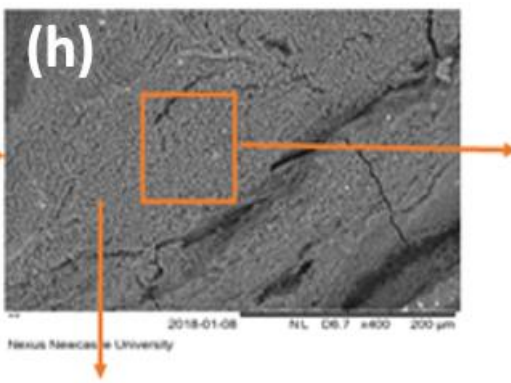

Latex binder with cells

Fig. S14 SEM images of the biocomposites after 8 weeks of net $\mathrm{CO}_{2}$ fixation testing (semi-batch); (a-c) $C$. 
(a)
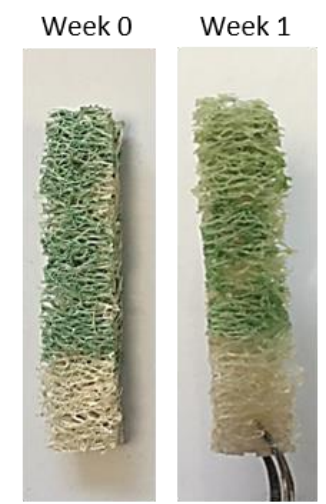

(b)

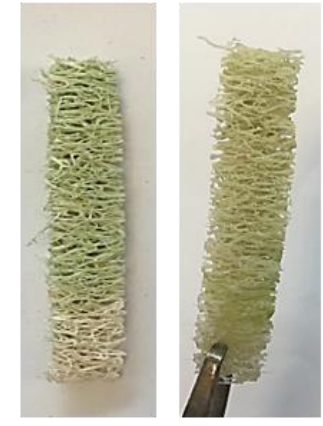

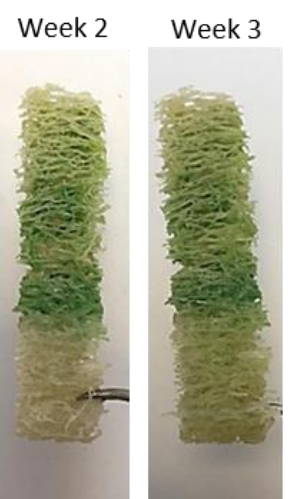
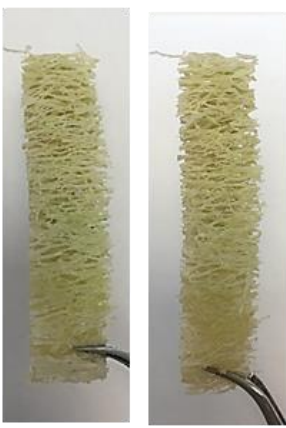
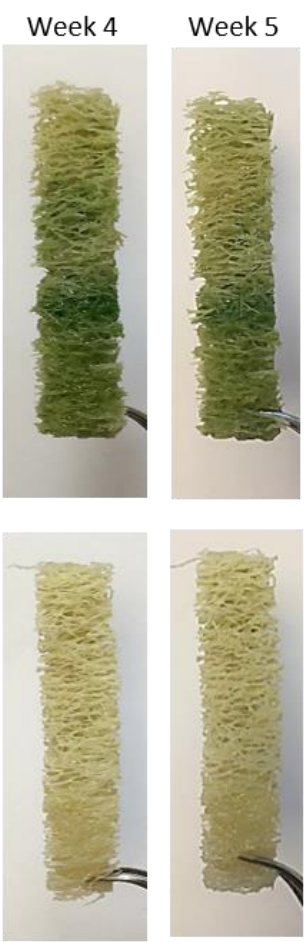
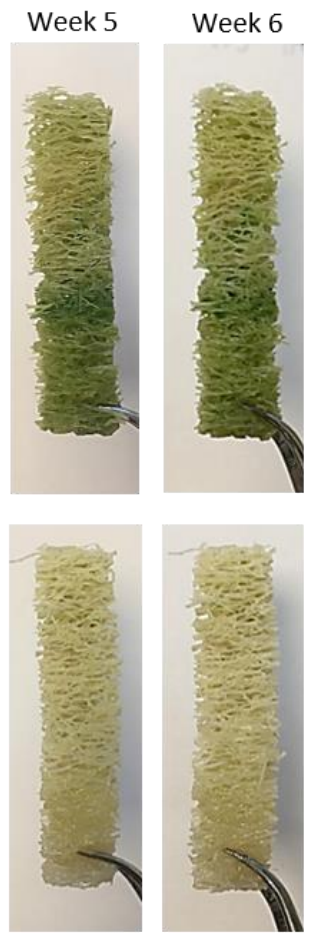

Week 7

Week 8
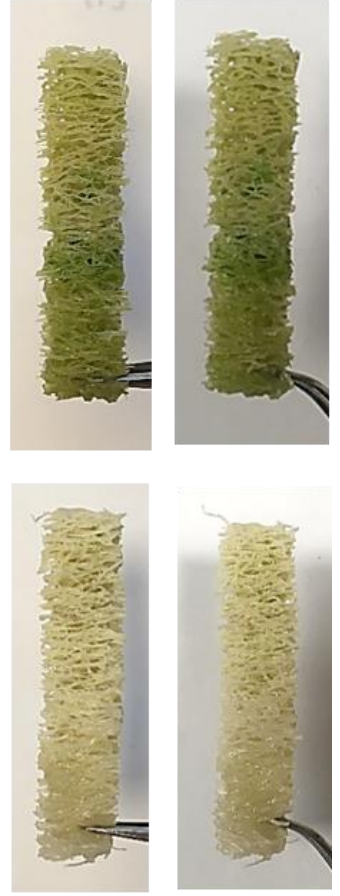

$1 \mathrm{~cm}$

432 Fig. $\mathbf{S 1 5}$ Development of representative $S$. elongatus biocomposites during the 8 weeks net $\mathrm{CO}_{2}$ fixation test 433 (semi-batch); (a) PCC 7942 + binder B5, (b) CCAP 1479/1A + binder B6.

434

435

436

437

438

439

440

441

442

443 

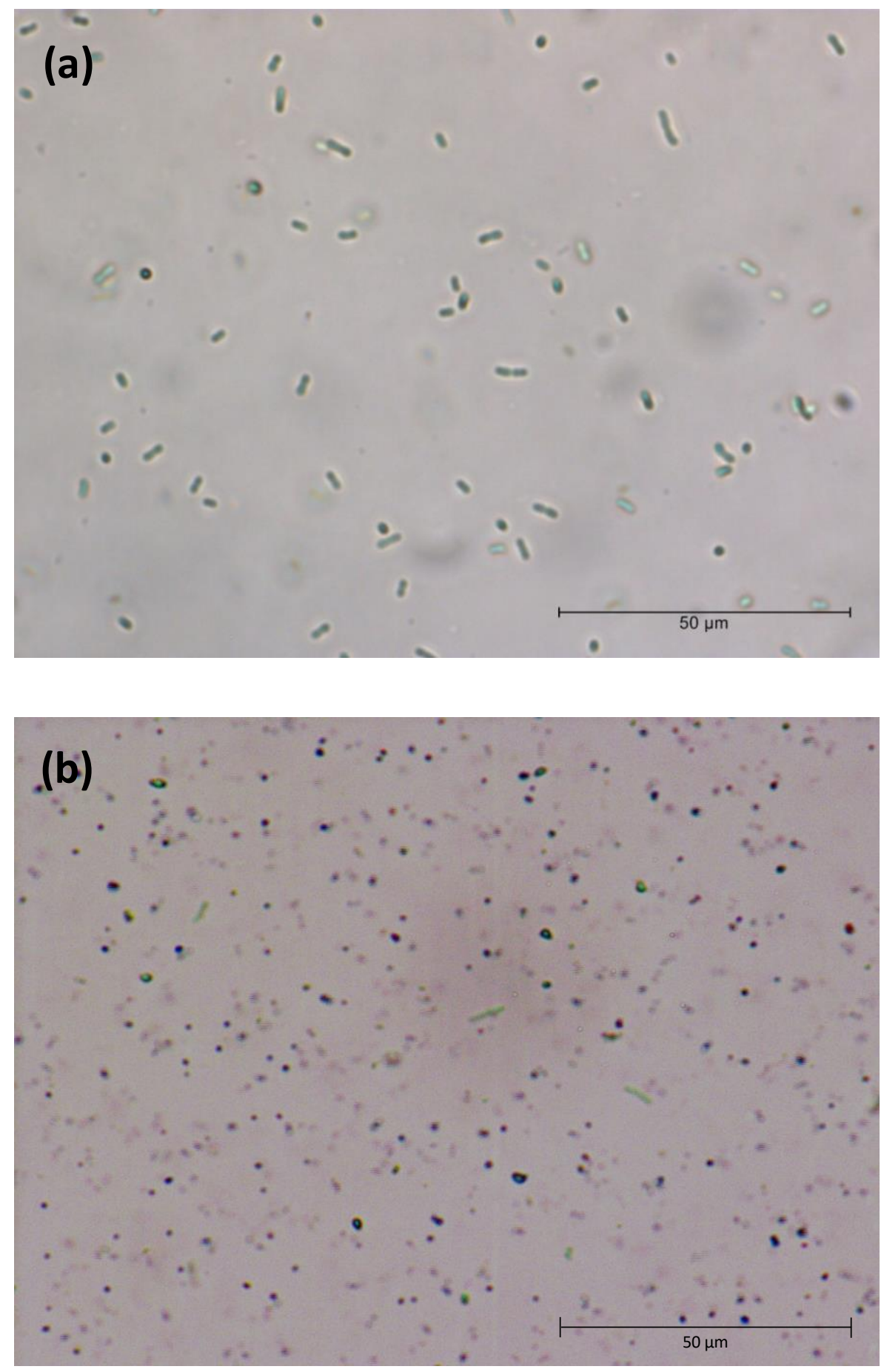

446 Fig. S16 Light micrographs of S. elongatus PCC 7942 in: (a) BG11 growth medium (suspension control); and, 447 (b) exposed to binder B6 at day 7 of the toxicity test. Control cells had a more rod-like morphology compared with the generally more coccoid morphology of the binder exposed cells. 